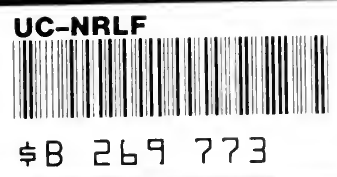



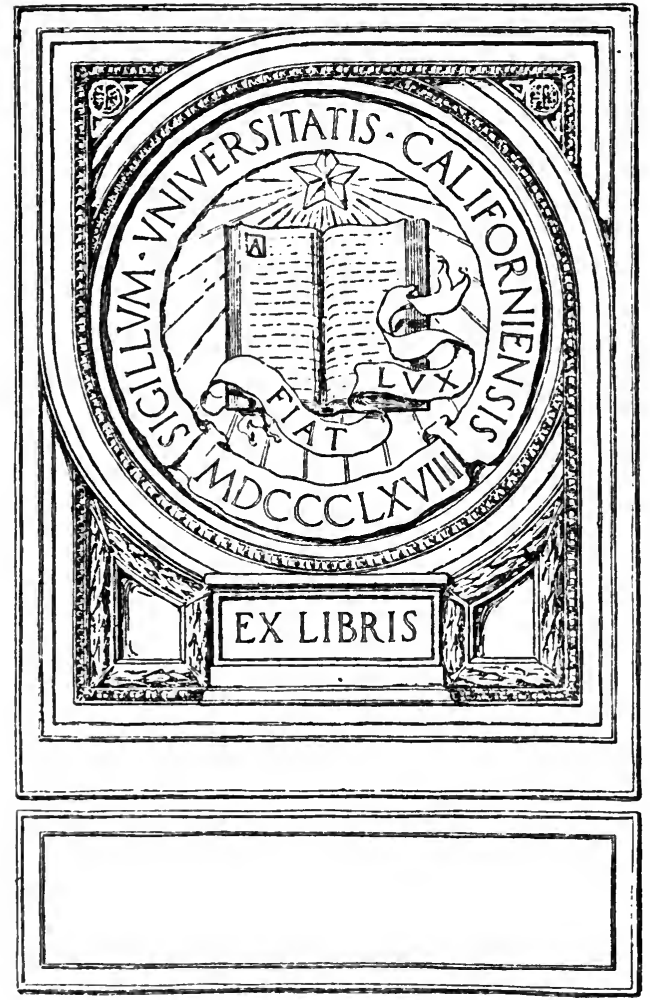
Digitized by the Internet Archive in 2007 with funding from

Microsoft Corporation

http://www.archive.org/details/judicialtenurein00carprich 


$$
\text { . }
$$




\section{JUDICIAL TENURE IN THE UNITED STATES}




\section{JUDICIAL TENURE}

\section{IN THE UNITED STATES}

WITH ESPECIAL REFERENCE TO

THE TENURE OF FEDERAL JUDGES

WILliam S. CARPEN'TER, Ph.D.

DEPARTMENT OF POLITICAL SCIENCE UNIVERSITY OF WISCONSIN

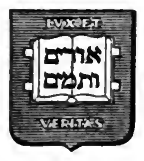

NEW HAVEN

YALE UNIVERSITY PRESS

LONDON: HUMPHREY MILFORD

OXFORD UNIVERSITY PRESS

MDCCCCXVIII 


\section{$J / 1533$ \\ $C_{3}$}

COPYRIGHT, 1918, BY
YALE UNIVERSITY PRESS

First published, April, 1918 


\section{PREFACE}

The following study is designed to present the historical development of two phases of the American judicial system: the influence of the exercise of the doctrine of judicial review upon the position of the courts, and the political reactions affecting the tenure of the judges.

The growth of the doctrine of judicial review in the formative period of American institutions had a profound influence upon subsequent constitutional development. When the judges, with popular approval, became the custodians of the Constitution a really independent judiciary became necessary to enable the courts fearlessly to mark out the provinces of the other departments of government. Attempts to check the exercise of judicial power have invariably taken the form of assaults upon the security of tenure of the judicial office. But even in the heat of partisan conflict the courts have usually withstood the attacks of persons who 
would destroy their independence. And in the end popular sentiment has generally supported the courts.

The relative merits of appointive and elective courts have been a topic of much discussion. But conclusions based on a comparative study of the results of these two modes of selection are almost valueless. The method of selecting judges is best determined by local conditions. It is by keeping the courts free from executive or legislative control and removing them from the influence of temporary popular majorities that the independence of the judiciary is maintained.

The study has dealt chiefly with the tenure of the federal judges, although popular movements which have resulted in important changes in the State courts have been considered. At the close of the narrative a chapter of conclusions summarizes the problems involved in securing the tenure of the judicial office at the present time.

I wish to acknowledge my indebtedness to Professor Henry Jones Ford of Princeton University for helpful suggestions. My associates in the Department of Political Science in the University of Wisconsin have 


\section{PREFACE}

vii

read portions of the manuscript and have made important corrections. To Professor Edward S. Corwin of Princeton University I am especially indebted not only for the reading of the entire manuscript but for valuable suggestions and stimulating criticism throughout the preparation of the work.

\section{WILLIAM S. CARPENTER.}

Madison, Wisconsin,

December 10, 1917. 


$$
\text { . }
$$




\section{CONTENTS}

PAGE

Preface

Chapter I. Establishment of a Federal Judiciary . 1

Chapter II. Congress and the Inferior Courts . $\quad 51$

Chapter III. The Removal of Judges 101 Chapter IV. Selection and Tenure of Judges · · . 155

Chapter V. Conclusions . . 194 Index . . . . . . 225 



\section{CHAPTER I;}

\section{ESTABLISHMENT OF A FEDERAL JUDICIARY}

The judiciary in the United States has become an institution of paramount importance, enjoying a security of tenure and a scope of influence elsewhere unknown among modern governments. It has been said that in this country we have no law until the courts have had opportunity to pass upon the validity of legislative enactments and have admitted them to be in harmony with the Constitution. Yet this great power lodged in the courts flows from fundamental principles and is, indeed, a cornerstone of American government.

That the courts of the United States may be competent to exercise the great functions laid upon them, involving as they do a check upon legislative action, judicial independence is peculiarly essential. Such independence demands that the judges shall not only 
be free from executive and legislative control, but that they shall be free from the political vagares of the people themselves, in order that within their sphere of governinent the cours may move unhindered and without fear. To secure such conditions has been the conscious effort of civil polity throughout the history of our nation.

\section{I}

The colonial judiciary had been the subject of bitter complaint. One of the grievances cited in the Declaration of Independence against George III was that "he has made judges dependent upon his will alone for the tenure of their offices and the amount and payment of their salaries." This, moreover, was contrary to the practice in England where one of the reforms of the Long Parliament had been the establishment of judicial commissions during good behavior. ${ }^{1}$ The same tenure had been granted the colonial judges down to 1761 when the King, acting upon the advice of the Board of Trade, altered the commissions to a tenure during the royal pleasure on the ground that

1 Cobbett: Parliamentary History, ii, p. 702. 
the state of learning in the colonies was so low that it was with difficulty that men could be found competent to administer the judicial offices. $^{2}$ In August, 1772, the King, finding that the want of a fixed allowance in the colonies for the administration of justice made judicial office very unattractive and prevented the establishment of an effective judiciary system, granted a salary to the judges of the superior court of Massachusetts, forbidding them to receive the customary grants from the House of Representatives, and the Council and Governor. This action of the King aroused much opposition, and a discussion in the public press followed in which John Adams in a series of essays condemned the subjection of the colonial judiciary to the crown. ${ }^{3}$ Popular resentment rose to such heights, indeed, that an attempt was made in 1774 to impeach Chief Justice Oliver before the assembly, and grand jurors and petit jurors refused to take their oaths in his court. ${ }^{4}$

2 N. C. Colonial Records, vi, pp. 582-586.

3 Adams: Writings, iii, p. 513 et seq.

4 Ibid., i, pp. 315-317. 


\section{II}

As a result of this experience, the colonists embarked upon the business of establishing judicial departments in their first State constitutions with no little concern. In theory it was universally agreed that the judges must be independent, and to this end the usual tenure in the early constitutions was during good behavior. This was the tenure provided in the constitutions of Massachusetts, Delaware, Maryland, Virginia, North Carolina, South Carolina, and in those drawn up in New Hampshire and Vermont. ${ }^{5}$ New York had the same tenure, except that there the judges retired at the age of sixty years. ${ }^{6}$ In Pennsylvania and New Jersey the appointments were for seven years. ${ }^{7}$ In Connecticut and Rhode Island, where they did not frame constitutions but continued their charter governments, the judges were still appointed annually by the legislature. In Georgia the people elected their judges annually. ${ }^{8}$

5 Thorpe: Charters and Constitutions, pp. 564, 1689, 1905, 2466, 2791, 3246, 3746, 3817.

( Ibid., p. 2634.

7 Ibid., pp. 2596, 3088.

8 Horace Davis: American Constitutions, J. H. U. Studies, Series 3, p. 507. 
But the principle of legislative supremacy, which in 1776 was so dominant both in England and in the colonies, caused much influence over the judiciary to be exercised by the assemblies. In most of the States the legislature controlled the appointment of the judges. In Connecticut, Rhode Island, New Jersey, Virginia, North Carolina, and South Carolina the legislature appointed directly. ${ }^{9}$ In New Hampshire, Massachusetts, Pennsylvania, and Maryland the appointments were made by the Governor and Council, while in New York the Governor acted with a special Council of Appointment. ${ }^{10}$ Judicial appointments in Delaware were made by the legislature and the executive. ${ }^{11}$

On the other hand, the theoretical basis on which the revolutionary state governments rested was a separation of the powers of government as laid down by Montesquieu, and on paper this doctrine was well defined. In practice, however, the case was very different. The Massachusetts constitution of 1780 declared that:

9 Thorpe: pp. 533, 2596, 2791, 3218, 3246, 3817.

10 Ibid., p. 2633.

11 Ibid., p. 564. 
In the government of this commonwealth, the legislative department shall never exercise the executive and judicial powers, or either of them; the executive shall never exercise the legislative and judicial powers, or either of them; the judicial shall never exercise the legislative and executive powers, or either of them; to the end that it may be a government of laws, and not of men. ${ }^{12}$

But we find Madison saying:

If we look into the constitutions of the several States we find that, notwithstanding the emphatical and, in some instances, the unqualified terms in which this axiom has been laid down, there is not a single instance in which the several departments of power have been kept absolutely separate and distinct. . . . It is but too obvious that in some instances the fundamental principle under consideration has been violated by too great a mixture, and even an actual consolidation of the different powers; and that in no instance has a competent provision been made for maintaining in practice the separation delineated on paper. ${ }^{13}$.. The legislative department is everywhere extending the sphere of its activity, and drawing all power into its impetuous vortex.... The conclusion which I am warranted in drawing is, that a mere

12 Thorpe: p. 1898.

13 Federalist, xlvii. 
demarcation on parchment of the constitutional limits of the several departments, is not a sufficient guard against those encroachments which lead to a tyrannical concentration of all the powers of government in the same hands. ${ }^{14}$

In some States efforts were made to erect barriers against the encroachments of the legislature. In New York the Governor, the Chancellor, and the judges of the supreme court were to form a council of revision which had power to veto acts of the legislature. ${ }^{15}$ The Pennsylvania constitution of 1776 included a provision for a Council of Censors who should meet in 1783 and in every seventh year thereafter. This council was to examine into the conduct of the government and had power "to pass public censures, to order impeachments, and to recommend to the Legislature the repealing such laws as appear to them to have been enacted contrary to the principles of the constitution." ${ }_{16}$ The same provision was copied into the constitution of Vermont where it continued in use down to 1869.

14 Federalist, xlviii.

15 Thorpe: p. 2628.

16 Ibid., p. 3091. 
These provisions were ineffective and contributed neither to check the legislature nor to elevate the judiciary. In his "Notes on Virginia" Jefferson made the criticism that all powers of government resulted to the legislative body. He pointed out that:

The convention which passed the ordinance of government laid its foundation on this basis, that the legislative, executive, and judiciary departments should be separate and distinct, so that no person should exercise the powers of more than one of them at the same time. But no barrier was provided between the several powers. The judiciary and executive members were left dependent on the legislative for their subsistence in office, and some of them for their continuance in it. If, therefore, the legislature assumes executive and judiciary powers, no opposition is likely to be made. ... They have, accordingly, in many instances, decided rights which should have been left to judicial controversy; and the direction of the executive during the whole time of their session is becoming habitual and familiar. ${ }^{17}$

The Pennsylvania Council of Censors at their meeting in 1783 considered the constitution defective in vesting all legislative power in a single house of representatives, "because an 17 Works (ed. Ford), viii, p. 362. 
uncontrolled power of legislation will always enable the body possessing it to usurp both the judicial and the executive authority, in which case no remedy would remain to the people but by a revolution." At the same time they recommended that the judges be granted a tenure during good behavior be- cause, being commissioned for seven years, "if the assembly should pass an unconstitutional law, and the judges have virtue enough to refuse to obey it, the same assembly could instantly remove them.' 18

The extent of the encroachments by the legislature was perhaps most widespread in Vermont. $^{19}$ The judiciary was completely subordinated to the legislature, and the latter department made rules, granted new trials, and vacated and annulled judgments. The courts refused to review the constitutionality of legislative enactments, declaring that "a mode of procedure pointed out by statute cannot be turned from although in derogation

18 Conventions of Pa. (1776-1790), p. 70.

19 In Pennsylvania the legislature was not considered to be limited in the same degree as were the other departments of government. Resp. v. Buffington, 1 Dallas 61. See also Calder v. Bull, 3 Dallas 386, and Cooper v. Telfair, 4 Dallas 13. 
of the common law. Such action by the courts would be to assume an arbitrary power not warranted by law.",

But it could not be expected that any doctrine of this sort should enjoy very long existence. Its early success was due partly to the popularity of the legislature in colonial times and partly to the fact that in most . States those who had framed the constitutions became the legislators. On the other hand, the case for the American revolution had been built upon the idea that acts contrary to natural right and justice were null and void, and in the famous controversy over the Writs of Assistance, James Otis had denied the right of Parliament to determine ultimately the validity of its own acts. ${ }^{21}$

More important than this political theory was the substantial fact that under legislative dominance the States were becoming involved in confusion and chaos. Paper money legis-

20 Paine v. Ely, 1 Chipman's Reports 37. "No idea was entertained (in Vermont) that an act of legislature, however repugnant to the constitution, could be adjudged void and set aside by the judiciary, which was considered by all a subordinate department of government." Chipman: Memoir of Thomas Chittenden, p. 112.

21 See Haines: Conflict over Judicial Powers, Ch. 1. 
lation and stay laws became such a menace to domestic peace and prosperity that the respectable element began to consider what curb might be applied to the legislature. ${ }^{22}$

\section{III}

In the reaction against legislative omnipotence judicial review was born. As early as 1780 the supreme court of New Jersey in the case of Holmes v. Walton had set aside as unconstitutional an act of the legislature which provided that in certain classes of cases a jury might consist of six men. ${ }^{23}$

22 Beard: Supreme Court and the Constitution, p. 75.

23 Some writers have claimed the Josiah Philips case which arose in Virginia in 1778 as one of judicial review. See article by William P. Trent, American Historical Review, i, pp. 444-454, and Haines: American Doctrine of Judicial Supremacy, pp. 77-80. But in the Jefferson MSS, in the Library of Congress under date of August 15, 1815, is to be found a letter from Jefferson to William Wirt which proves conclusively that in the case of Josiah Philips there arose no question of judicial review. In speaking of the case Jefferson says: "I remember the case and took my part in it. Philips was a mere robber, who availing himself of the troubles of the times, collected a banditti, retired to the Dismal Swamp, and from thence sallied forth, plundering and maltreating the neighboring inhabitants, and covering himself, without authority, under the name of a British subject. Mr. Henry, then Governor, communicated the case to me. We both thought the best proceeding would 
Several protests were sent in to the legislature by the inhabitants of the counties interested in the act adjudged void, but generally the court was sustained. The following year that part of the act relating to a sixman jury was repealed and it was enacted that "it shall be lawful for either of the parties to such suit to demand a jury of twelve men, which jury the justice shall be empowered to grant." ${ }^{24}$

Although this decision attracted some attention, ${ }^{25}$ the gains to the judicial power were not great because of the incomplete recognition given the doctrine of judicial review by the legislature. The manner in which the be by bill of attainder, unless he delivered himself up for trial within a given time. Philips was afterwards taken; and Mr. Randolph being Attorney General and apprehending he would plead that he was a British subject, taken in arms, in support of his lawful sovereign, and as prisoner of war entitled to the protection of the law of nations, he thought the safest proceeding would be to indict him at common law as a felon and robber. Against this, I believe, Philips urged the same plea; but was overruled and found guilty."'

24 Austin Scott: American Historical Review, iv, p. 456. 25 Gouverneur Morris in 1785 pointed out that "a law was once passed in New Jersey, which the judges pronounced unconstitutional, and therefore void." Sparks: Life of Morris, iii, p. 438. 
repeal was enacted must be considered as a compromise which, while not denying the right of the courts to pass upon the constitutionality of legislative enactments, left to the legislature in the last analysis the power to define by statute the functions of each department of government. Nor was any contribution to the judicial power secured by the obiter dicta of the judges of the Virginia Court of Appeals in the decision of Commonwealth v. Caton in 1782. The judges were of the opinion "that the court had power to declare any resolution or act of the legislature, or either branch of it, to be unconstitutional and void." ${ }^{26}$ But since the case did not call for the exercise of this power it is not known how these views were received.

The next case to receive attention was that of Rutgers v. Waddington decided in the mayor's court in New York City in 1784. ${ }^{27}$ Far from asserting the doctrine of judicial review the court in this case merely laid claim on behalf of the judiciary to a judicial dis264 Call 5.

27 The action was one of trespass brought upon a statute of March 17, 1783. Plea was made that the act was in contravention of the law of nations and the treaty of peace of 1783 . 
cretion within the limits of Blackstone's tenth rule for construing statutes. Closely following Blackstone, the court observed:

The supremacy of the legislature need not be called into question; if they think positively to enact a law, there is no power which can control them. When the main object of such a law is clearly expressed, and the intention is manifest, the judges are not at liberty, although it appears to them to be unreasonable, to reject it; for this were to set the judicial above the legislative, which would be subversive of all government. But when a law is expressed in general words, and some collateral matter which happens to arise from those general words is unreasonable, there the judges are in decency to conclude that the consequences were not foreseen by the legislature; and therefore they are at liberty to expound the statute by equity and only quoad hoc to disregard it. When the judicial make these distinctions, they do not control the legislature; they endeavor to give their intention its proper effect. ${ }^{28}$

Even this modest assertion by the judiciary of the right to interpret a statute when not plainly expressed was considered in conflict with the power given the Council of Revision to object to laws deemed improper 28 Coxe: Judicial Power, p. 230. 
by them. On this ground the decision was seized upon by the "violent Whigs," as those of the Clinton party were called, and an effort was made to use it as political capital. A public meeting was called on September 13, and an address to the people was prepared. At the meeting of the legislature in the following month an attempt was made to pass resolutions of censure upon the mayor and aldermen and to recommend to the Council of Appointment "that at their next appointments they appoint such persons to be Mayor and Recorder of the City of New York as will govern themselves by the known laws of the land." The resolutions gave rise to an extended debate in the assembly during which the records were brought up for examination but with the result that the matter was dismissed. ${ }^{29}$

Because of the complicated situation involved in the New York case and the fact that the decision was used to further partisan politics it is difficult to ascertain what was the real attitude of the people toward the doctrine of judicial review even in the limited scope laid down by the mayor's court. But 29 Dawson: Pamphlet of Case of Rutgers v. Waddington. 
two years later we find popular sympathy enlisted in support of the judiciary in the exercise of judicial review. In the autumn of 1786 the now celebrated case of Trevett v. Weeden came before the superior court of Rhode Island for decision. During the previous year the paper money party had gained control of the state government and proceeded to enter upon a career of "rag money" enactments indicative of fraud, ignorance and folly. Many merchants refused to accept the paper money as legal tender despite the fact that the legislature had declared a penalty of one hundred pounds for such refusal and denied the right of trial by jury in such cases. One of these merchants, John Weeden, was sued by a paper money fanatic by the name of Trevett when he declined to accept bills of credit as legal tender. ${ }^{30}$

The defendant averred that the court could not take cognizance of the case; that the act constituting three judges of the supreme court without a jury a special court for the trial of such cases was unconstitutional. The

30 Coxe: pp. 234-235. Carey: American Museum, v, pp. 36-38. 
counsel for the defense, James M. Varnum, in a forceful argument to the court asserted the independence of the judiciary. "The legislature," he said, "have the uncontrollable power of making laws not repugnant to the constitution. The judges have the sole power of judging those laws and are bound to execute them; but cannot admit any act of the legislature as law which is against the constitution.", In giving their decision, however, the judges seem to have desired to avoid the main issue by declaring "that the information was not cognizable before them." But the judgment of the court must be considered as having rejected the statute as void. ${ }^{32}$

The legislature, mortified and chagrined, ordered the judges before them to explain their action and three of them appeared, the chief justice being prevented by illness from attending. After the judges had been heard in their own defense, an animated discussion arose among the members of the assembly as to whether they were satisfied with the rea31 Coxe: p. 242. Varnum: Pamphlet (in New York Free Library).

32 Coxe: p. 245. 
sons given by the judges in support of their decision, but the opponents of the judges prevailed and a motion was made to dismiss them from office.

In the meantime a petition was received from the judges asking a hearing by counsel before a legal and proper tribunal, and the assembly agreed to hear James M. Varnum in their defense. Varnum argued that whether the judgment of the court was right or wrong, the judges could not be brought to answer for it except by due course of law. He pointed out that their tenure was not during the pleasure of the assembly but for a period of one year, and their removal could not be effected during that time except upon conviction in open court of some crime, neglect, or abuse of trust.

The memorial and the address strongly impressed the legislature and they decided to ask the advice of the attorney general. Motion was made to inquire if the assembly, agreeably to law and the constitution, could remove or suspend from office the judges of the supreme judiciary court, without previous charge, due process of law, trial and conviction thereon. The opinion of Mr. Channing, 
the attorney general, and other lawyers being unfavorable to such action by the assembly, the judges were not removed. Their judgment was condemned by a large majority of the legislature but no charge of criminality being made, the matter was dismissed. The judges were not, however, re-elected at the next election. ${ }^{33}$

In North Carolina the doctrine of judicial review was asserted in 1787. On May 29, as the convention to amend the Articles of Confederation was assembling in Philadelphia, the court of conference, the highest tribunal in North Carolina, handed down a decision in the case of Bayard v. Singleton. ${ }^{34}$ The court seems to have made every effort to avoid a conflict with the legislature but in the end was obliged to set aside as invalid a "quieting act.",

This was the first case in which a conflict arose between a clause in a written constitution and an act of a legislature. The judges in the case were denounced as usurpers of 33 Chandler: Criminal Trials, ii, p. 336.

34 Maryland Gazette, July 3, 1787.

351 Martin 42. The act in question was designed to secure in their possession all persons who had purchased lands sold by the commissioners of forfeited estates. 
power, Richard Dobbs Spaight, a member of the federal convention, declaring that "the State was subject to three individuals, who united in their own persons the legislative and judicial power, which no monarch in England enjoys. ...., $\mathrm{,36}$ was answered by James Iredell who insisted that:

An act inconsistent with the constitution was void; and that the judges, consistently with their duties, could not carry it into effect. The constitution appears to me to be a fundamental law, limiting the powers of the legislature, and with which every exercise of those powers must, necessarily, be compared. Without an express constitution the powers of the legislature would undoubtedly have been absolute, and any act passed not inconsistent with natural justice (for that curb is avowed by the judges even in England), would have been binding on the people. ${ }^{37}$

As a result of the exercise of the doctrine of judicial review the courts came to occupy a far more independent position than they had hitherto enjoyed. They now had a weapon upon which they could rely, enabling them to define the functions to be ascribed to

36 Coxe: p. 386.

37 McRee: Life of James Iredell, ii, p. 172. 
each department of government. Moreover, in the exercise of this new-found power they had gained popular support. ${ }^{38}$ Gouverneur Morris in 1785 declared that "such power in judges is dangerous; but unless it somewhere exists, the time spent in framing a bill of rights and form of government was merely thrown away.',39 In the case of the North Carolina judges "charges were brought against them in the legislature, but they were eventually sustained by public opinion.',40 The Rhode Island judges, despite the positive assurances that the next election would see them replaced by others more favorable to the party in control of the legislature, stood firm against the paper money enactments. The court was moved in one case by way of experiment to cause the bills to be counted,

38 Respecting conditions in New Hampshire in 1786, a letter of William Plumer declares: "The aspect of public affairs in this state is gloomy. Money is scarce; business is dull, and our feeble government is unhinged. Yet, even in these degenerate days, our courts of law are firm, and dare to be honest. If our elective government is to be long supported it will owe its existence merely to the wisdom and independence of the courts." Plumer: Life of William Plumer, p. 166.

39 Sparks: Life of Morris, iii, p. 438.

40 Coxe: p. 252. 
and to direct the clerk to record the tender. After due consideration of this motion, the court determined that they had nothing to do with paper bills; and the chief justice took the handkerchief containing them from the table and returned it to the owner, saying to him: "The court have determined that we have nothing to do with your money."

\section{IV}

The federal convention was fully cognizant of the need for the establishment of a national judiciary which should be clothed with such power as would enable it to maintain an independent position as one of the great departments of government. Its members were ready to define sharply the province of each department in the new government and to provide such checks and balances as would prevent such encroachments of the legislature as prevailed in the states. Randolph in presenting his ninth resolution on May 29, 1787, remarked that "our chief danger arises from the democratic parts of our constitutions. It is a maxim which I hold incontrovertible that the powers of government ex41 Virginia Independent Chronicle, May 9, 1787. 
ercised by the people swallow up the other branches. None of the constitutions have provided sufficient checks against the democracy." 42

The plan suggested by Randolph called for the establishment of one or more supreme tribunals and of inferior tribunals to be chosen by the national legislature. The judges were to hold their commissions during good behavior and were to receive a fixed compensation which should be neither increased nor diminished during their term of service. ${ }^{43}$ The New Jersey or "small state", plan submitted on June 15 differed from that of Randolph in that but one supreme tribunal to be chosen by the executive was provided. ${ }^{44}$

The separation of the judicial from the legislative power was equally desired with the independence of the courts. Many of the members of the convention wished to join the judges in the making of laws and to that end proposed to associate them with the executive in a Council of Revision to pass upon acts of the national legislature. The friends

42 Farrand: Records of the Federal Convention, i, p. 26. 43 Ibid., p. 21.

44 Ibid., ii, p. 74. 
of this proposition urged that it would enable the judiciary to defend itself against the encroachments of the legislature, would inspire the executive with additional confidence and firmness, and would be useful to the legislature by the valuable assistance it would give in preserving a consistency and technical propriety in all laws. ${ }^{45}$

But the provision for a Council of Revision was rejected because its opponents thought that the power of making ought to be kept separate from that of expounding the laws. Mercer declared that "it is an axiom that the judiciary ought to be separate from the legislative, but equally so that it ought to be independent of that department." ${ }_{46}$ Charles Pinckney thought that the interference of the judges in legislative business would involve them in parties and give a previous tincture to their opinions, while Rutledge insisted that "the judges ought never to give their opinion on a law until it comes before them."

The independence of the judicial department against encroachments by the legisla45 Farrand: ii, p. 74.

46 Ibid., ii, p. 298.

47 Ibid., ii, p. 80. 
ture was felt to be amply protected by the power of judicial review vested in the courts. That the framers of the Constitution intended that the courts of the United States should have the power to review legislative enactments setting aside such as might be in conflict with the Constitution has been substantially proved by recent investigations. ${ }^{48}$

The members of the convention were fully informed as to the success of the doctrine of judicial review in the various state courts where it had been set forth. On June 4, Gerry pointed out that "in some states the judges had actually set aside laws as being against the constitution. This was done, too, with general approbation." ${ }^{49}$ At this time he must have been in possession of information regarding all the cases mentioned above. At the same time he doubted whether in the formation of a Council of Revision "the judiciary ought to form a part of it, as they will have a sufficient check against encroachments on their own department by their exposition of the laws which involves a power 48 Beard: Supreme Court and the Constitution. E. S. Corwin: Michigan Law Review, ix, pp. 102, 283.

49 Farrand: i, p. 97. 
of deciding on their constitutionality." ${ }_{50}$ In this view he was supported by Luther Martin, who added that "as to the constitutionality of laws, that point will come before the judges in their proper official character. In this character they have a negative on the laws." ${ }^{51}$

Those who desired the establishment of the Council of Revision were entirely in accord with its opponents in the view that the courts might pass upon the constitutionality of acts of the legislature. But Wilson held that this power of the judges did not go far enough. "Laws," he said, "may be unjust, may be unwise, may be dangerous, may be destructive, and yet not be so unconstitutional as to justify the judges in refusing to give them effect." ${ }_{52}$ Nevertheless despite the argument of Madison that the proposition would not be "any violation of the maxim which requires that the great departments of power be kept separate and distinct," the proposed Council of Revision was defeated and the revision of unconstitutional legislation left to the discretion of the judiciary ${ }^{53}$

50 Farrand: i, p. 97.

51 Ibid., ii, p. 26.

52 Ibid., ii, p. 73.

53 Ibid., ii, p. 76. 
But while the intention of the convention with respect to the judicial review of acts of Congress was not followed by specific constitutional provisions, because such power was thought to flow from fundamental principles, the same power with respect to State legislation which might conflict with the Constitution was guaranteed by a particular article in the new draft of government. In the original plan proposed by Randolph was an article giving the national legislature power "to negative all laws passed by the several states contravening the articles of union." ${ }^{54}$ This provision was accepted until it was challenged on June 20 by John Lansing who said: "It is proposed that the general legislature shall have a negative on laws of the states. Is it conceivable that there will be leisure for such a task? There will, on the most moderate calculation, be as many acts sent up from the states as there are days in the year. Will the members of the general legislature be competent judges? Will a gentleman from Georgia be a judge of the expediency of a law which is to operate in New Hampshire?

54 Farrand: i, p. 21. 
Such a negative would be more injurious than that of Great Britain heretofore was. " 55

The question of expediency being raised, a host of objections to the proposition were brought forward. Sherman "thought it unnecessary, as the courts would not consider as valid any law contravening the authority of the union, and which the legislature would wish to be negatived." "56 Gouverneur Morris "was more and more opposed to the negative," maintaining that "a law that ought to be negatived would be set aside in the judiciary department." ${ }_{57}$ But Madison warned them that "confidence cannot be put in the State tribunals as guardians of the national authority and interests." ${ }^{58}$ A happy solution of the difficulty was reached when Luther Martin proposed "that the legislative acts of the United States ... shall be the supreme law of the respective States ... and that the judiciaries of the several States shall be bound thereby in their decisions, anything in

55 Farrand: i, p. 337.

56 Ibid., ii, p. 27.

57 Tbid., ii, p. 28.

58 Ibid., ii, p. 27. 
the respective laws of the individual States to the contrary notwithstanding."

That the independence of the judges might be secured, the superiority of commissions during good behavior was never doubted in the course of the convention. Towards the close of the session, on August 27,

Dickinson moved an amendment to provide that judges might be removed by the Executive on application by the Senate and the House of Representatives. Gouverneur Morris thought it a contradiction in terms to say that the judges should hold office during good behavior and yet be removable without trial. Besides it was fundamentally wrong to subject judges to so arbitrary an authority. Mr. Sherman saw no contradiction or impropriety if this were made a part of the constitutional regulation of the judiciary establishment. He observed a like provision was contained in the British statutes.

Mr. Rutledge: If the Supreme Court is to judge between the United States and particular states, this alone is an insuperable objection to the motion.

Mr. Wilson considered such a provision in the British constitution as less dangerous than here, the House of Lords and the House of Commons being less likely to concur on the same occasions. 59 Farrand: ii, p. 29. 
Chief Justice Holt, he remarked, had successively offended by his independent conduct, both Houses of Parliament. Had this happened at the same time he would have been ousted. The judges would be in a bad situation if made to depend on every gust of faction which might prevail in the two branches of our government. Mr. Randolph opposed the motion as weakening too much the independence of the judges. ${ }^{60}$

On Dickinson's motion being put, only one State voted in the affirmative. Hamilton admits that the want of a provision for the removal of federal judges on address was the subject of complaint. ${ }^{61}$ But the records show that the preponderant opinion of the members of the convention was that such a provision would be inconsistent with the independence they deemed necessary to the judicial department.

To such lengths was the demand for an independent judiciary carried that Madison objected to permitting an increase in salaries of the judges during their term of service on the ground that "whenever an increase is wished by the judges, or may be in agitation ${ }^{60}$ Farrand: ii, pp. 423, 428.

61 Federalist, lxxix. 
by the legislature, an undue complaisance in the former may be felt towards the latter." But this objection was overruled because it was equally clear that if there was no power to increase their pay according to the increase of business during the life of the judges, it might happen that there would be such an accumulation of business as would reduce the pay to a most trivial consideration. ${ }^{63}$

Debate on Randolph's plan for a federal judiciary centered on that part of the ninth resolution vesting the choice of judges in the national legislature. The opposition in committee of the whole was led by James Wilson who advocated an appointment by the executive. To this Rutledge refused to assent, claiming that such a method savored too much of monarchy. Uncertainty as to the real thoughts of the convention on this point was only too evident and Madison, feeling the need for more mature reflection, threw out the suggestion that this power be vested in the Senate and moved a postponement. ${ }^{\text {et }}$ When the subject was again discussed in 62 Farrand: ii, pp. 44-45.

63 Elliot: Debates, iii, p. 517.

64 Farrand: i, p. 120-321. 
committee, Charles Pinckney and Roger Sherman supported Rutledge in advocating an appointment by the national legislature. Madison objected that many of the members would be incompetent judges of the qualifications necessary for judicial office and proposed that "the appointment should be made by the Senate which, as a less numerous and more select body, would be more competent judges, but which was sufficiently numerous to justify confidence in them." ${ }^{\prime 65}$

The matter was resumed on July 18, when Mr. Gorham, with the provisions of the constitution of Massachusetts in mind, rose in convention and proposed that the judges be appointed by the executive, by and with the advice and consent of the Senate. The debate was somewhat extended and showed a marked preference on the part of the leaders for an appointment by the Senate alone. Yet it was equally evident that this preference was dictated by the fact that the Senate was to be small in numbers. Gouverneur Morris and James Wilson continued their opposition to an appointment by the second branch and it was not until quite late in the 65 Farrand: i, p. 232. 


\section{THE UNITED STATES}

session that the convention agreed to admit the executive as a participant in the exercise of this power and the present provision was drawn up. ${ }^{66}$ Some like Madison asserted that the union of the legislative and executive departments in the appointing power was effected only in order that the President might be guided by the advice of the Senate. ${ }^{.7}$ Others saw in the combination a restraint upon the executive and a further means of preventing him from becoming absolute. ${ }^{68}$

Thus far could the convention proceed without serious dissension in the establishment of a national judiciary. But they had secured merely the independence of the judges and a distinction between judicial and legislative functions. Wilson noted on the margin of his committee report that "the judicial should be commensurate to the legislative and executive authority." "ø9 To erect the judiciary as a co-ordinate department of government necessitated the consideration of numerous clauses respecting jurisdiction which are beyond the scope of this inquiry.

66 Farrand: ii, p. 539.

67 Ibid., iii, p. 357.

68 Ibid., iii, p. 358.

${ }^{69}$ Ibid., ii, p. 237. 
In one feature of their plan, however, the friends of a federal judiciary were defeated, and from this has sprung the claim of Congress to control within the judicial power. This was the failure to accept that part of the ninth resolution providing for the establishment of inferior courts.

Led by Rutledge, the advocates of States' rights made a vigorous assault from the first upon the proposition to create inferior courts. Rutledge argued that:

The State tribunals might and ought to be left in all cases to decide in the first instance, the right of appeal to the supreme national tribunal being sufficient to secure the national rights and uniformity of judgments. He considered that it was making unnecessary encroachments on the jurisdiction of the States, and creating unnecessary obstacles to their adoption of the system. ${ }^{70}$

He was supported by Sherman who dwelt upon the expensiveness of having a new set of courts when the existing State courts would answer the same purpose and a motion to strike out "inferior tribunals" passed by a vote of five to four.

James Wilson and Madison at once pro70 Farrand: i, p. 224. 
posed "that the national legislature be empowered to institute inferior tribunals," observing that there was a difference between establishing such tribunals absolutely and leaving their establishment to the discretion of the legislature. But Pierce Butler was strenuous in his opposition declaring:

The people will not bear such innovations. The States, he said, will revolt at such encroachments. Supposing such establishment to be useful we must not venture on it. We must follow the example of Solon who gave the Athenians not the best government he could devise but the best they would receive. ${ }^{71}$

Luther Martin was of the same opinion, arguing that the inferior courts would create jealousies and oppositions in the State tribunals, with the jurisdiction of which they would interfere. ${ }^{i 2}$ Gorham pointed out, however, that there were in the States already federal courts with jurisdiction for the trial of piracies committed on the high seas and that no complaints had been made either by the States or the courts of the States. Sherman suggested that the power be given the

71 Farrand: i, p. 125.

72 Ibid., ii, p. 46. 
legislature to establish inferior courts but thought that the State tribunals should be made use of whenever it could be done with safety to the general interest and the question was thereupon agreed to nem. con.

The provision as reported by the committee of detail read "such inferior courts as the Congress may from time to time, when necessary, ordain and establish." Again the friends of States' rights protested and the clause "when necessary", was omitted, leaving the creation of inferior courts entirely at the discretion of the national legislature. ${ }^{73}$

In the opinion of the writers of the Federalist the provisions for the establishment of a federal judiciary merited the greatest praise. Hamilton considered the "judiciary beyond comparison the weakest of the three departments of power" and that "liberty could have nothing to fear from the judiciary alone, but would have everything to fear from its union with either of the other departments." He therefore thought the tenure during good behavior and the fixed compen-

73 Farrand: ii, p. 172. 
sation guaranteed the judges to be necessary in order to guard the judiciary against the encroachments and oppressions of the legislative body. The doctrine of judicial review he maintains as a logical inference from the very structure of the Constitution. He points out:

There is no position that depends upon clearer principles, than that every act of a delegated authority, contrary to the tenor of the commission under which it is exercised, is void. No legislative act, therefore, contrary to the Constitution, can be valid.

If it be said that the legislative body are themselves the constitutional judges of their own powers, and that the construction they put upon them is conclusive upon the other departments, it may be answered that this cannot be the natural presumption, where it is not to be collected from any particular provisions in the Constitution. It is not otherwise to be supposed that the Constitution could intend to enable the representatives of the people to substitute their will to that of their constituents. It is far more rational to suppose that the courts were designed to be an intermediate body between the people and the legislature, in order, among other things, to keep the latter within the limits assigned to their authority. 
Nor does this conclusion by any means suppose a superiority of the judicial to the legislative power. It only supposes that the power of the people is superior to both; and that where the will of the legislature, declared in its statutes, stands in opposition to that of the people, declared in their Constitution, the judges ought to be governed by the latter rather than the former. They ought to regulate their decisions by the fundamental laws, rather than by those which are not fundamental. ${ }^{74}$

The distinction between legislative and judicial functions received confirmation at the very outset of the new government in the debate which took place in the first Congress on the propriety of vesting a power of removal in the hands of the President. There Madison claimed that the meaning of the Constitution might as well be ascertained by the legislative as by the judicial authority. ${ }^{75}$ But this view was not accepted by Congress, the predominant opinion being expressed by Gerry when he declared:

The judges are the expositors of the Constitution and the acts of Congress. Our exposition, therefore, would be subject to their revisal. The judiciary may disagree with us and undo what all

74 Federalist, lxxviii.

75 Elliot: iv, pp. 382-383, 399. 
our efforts have labored to accomplish. A law is a nullity unless it can be carried into execution: in this case our law will be suspended. Hence all construction of the meaning of the Constitution is dangerous or unnatural, and therefore ought to be avoided. This is our doctrine, that no power of this kind ought to be exercised by the legislature. ${ }^{76}$

The federal courts were not long in asserting their powers under the new government, becoming involved in a controversy with the legislature in 1792. On March 23 of that year, Congress passed an act "to provide for the settlement of the claims of widows and orphans barred by the limitations heretofore established, and to regulate the claims to invalid pensions.", By this act the circuit courts were bidden to receive and sit in judgment upon pension applications. Their decisions were to be referred to the secretary of war and might be subjected to revision by the legislature. ${ }^{77}$

The judges in a very respectful letter to the President protested that the duties assigned them were not judicial and that, while it was their duty to receive with all possible

76 Elliot: iv, p. 403.

77 U. S. Statutes at Large, i, pp. 243-245. 
respect every act of the legislature, they could not execute this act. ${ }^{78}$ The circuit judges for the New York district agreed to carry out the wishes of Congress in the capacity of commissioners, and wrote the President to this effect. $^{79}$ The judges for the North Carolina district agreed to adjudicate the claims in a similar manner, provided such procedure were constitutional. ${ }^{80}$

The circuit court for the Pennsylvania district consisting of Justices Wilson, Blair, and Peters were much more resolute in refusing to decide the pension claims. They made no protest until the question was raised before them by the presentation of a claim. On April 11, 1792, William Hayburn presented a petition to the judges asking to be placed upon the pension list. After due consideration the court refused to proceed in the matter and gave it no further attention. Hayburn then sent a memorial to Congress stating that the circuit court had refused to take cognizance of his case and begging them for

78 American State Papers, Misc., i, p. 52.

79 Ibid., p. 49.

80 Ibid., p. 52. 
relief. $^{81}$ The judges thereupon sent a communication to the President objecting that the business was not of a judicial nature and pointing out that since the act subjected their decision to a revision by the legislature and by the secretary of war it was radically inconsistent with the independence of the judicial power which is vested in the courts. They declared in closing: "These, sir, are the reasons for our conduct. Be assured, that, though it became necessary, it was far from being pleasant. To be obliged to act contrary either to obvious directions of Congress, or to a constitutional principle, in our judgment equally obvious, excited feelings in us which we hope never to experience again." "82

The novelty of the decision of the circuit court is said to have aroused much discussion and no little excitement. Some of the radicals advocated measures against the judges though no motion was made in Congress, towards their enactment. ${ }^{83}$ Hayburn petitioned the House of Representatives com81 Annals, 2d Cong., pp. 556-557.

82 American State Papers, Misc., i, p. 51.

83 Infra, p. 108. 
plaining against the action of the court and begging them to take cognizance of his case. ${ }^{84}$ A writ of mandamus was then sought from the supreme court to compel the inferior court to comply with the act of Congress. This the court held over for advisement until the next term, but no decision was rendered as the legislature in the meantime provided in another way for the relief of the petitioners. ${ }^{85}$

This action of Congress marks the first acceptance of an adjudication by the courts upon the validity of a legislative enactment. The refusal of the judges to proceed upon the petition of Hayburn is said to have produced a variety of opinions on the part of members of Congress with respect to the measures to be taken on the occasion. Mr. Murray urged the necessity of passing a law to point out some regular mode in which the judges of the courts of the United States should give official notice of their refusal to act under any law of Congress on the ground of unconstitutionality, but this he did not put in the form

84 Annals, 2d Cong., p. 556.

85 Hayburn's Case, 2 Dallas 409. 
of a motion. ${ }^{86}$ The recognition by Congress of the decision of the circuit court and the subsequent repeal of the act of 1792 gave a fortunate settlement to the dispute. The next year the supreme court decided that the judges who refused to adjudicate under the act of 1792 could not legally do so in the capacity of commissioners. ${ }^{87}$

The judges took further steps in 1793 to strengthen their position and to assert their independence of the other branches of government. During the controversy with M. Genêt, the French minister, as to his right to refit a captured English merchantman as a privateer at an American port, and then send her out for a cruise, the President asked the justices a series of questions comprehending all the subjects of difference as to the proper exposition of the provisions of our treaties with France under which her minister made claim. They replied that they deemed it improper to enter the field of politics by declaring their opinions on questions not growing out of some case actually before them. No further request of this kind 86 Annals, 2d Cong., i, p. 557. 87 U. S. v. Yale Todd, 13 Howard 52 (note). 
has since been made by any of the political departments to a court of the United States, except such as have been addressed to the court of claims. ${ }^{88}$

At the same time the progress of the judiciary in maintaining their power does not seem to have been impressive. On August 5, 1792, Edmund Randolph wrote Washington:

It is much to be regretted that the judiciary in spite of their apparent firmness in annulling the pension law, are not, what sometime hence they will be, a resource against the infractions of the Constitution on the one hand, and a steady assertion of federal rights on the other. So crude is our judiciary system, so jealous are our State judges of their authority, so ambiguous is the language of the Constitution that the most probable quarter from which an alarming discontent may proceed is the rivalship of these two orders of judges. ${ }^{89}$

John Jay resigned from the supreme court after a few years of service as chief justice feeling "perfectly convinced that under a system so defective it would not obtain the energy, weight, and dignity which are essential to its affording due support to the na-

88 Baldwin: The American Judiciary, p. 33. 89 Sparks: Life and Writings of Washington, x, p. 513. 
tional government, nor acquire the public confidence and respect which, as the last resort of the justice of the nation, it should possess." 90 While these opinions are from men who had expected a great deal from the federal judiciary, it is apparent that since down to the decision in Marbury v. Madison in 1803 only six cases had come before the supreme court involving questions of constitutional law, the people were still strongly attached to their State courts.

But about the close of Washington's second administration the judiciary became involved in partisan politics and began to assert their power with increased vigor. Anti-federalist and States' rights sentiment formed the basis for a division into political parties and the consequent growth of party spirit, which was regarded as destructive to constitutional government, seemed to strike at the root of the old order. "The very idea of the power and the right of the people to establish government,' said Washington in his farewell address, "presupposes the duty of every individual to obey the established government. All obstructions to the execution of the laws, 90 Jay: Correspondence, iv, p. 284. 
all combinations and associations under whatever plausible character, with the real design to direct, control, counteract, or awe the regular deliberations of the constituted authorities, are destructive of this fundamental principle and of fatal tendency.",

As one writer has pointed out, "the behavior of the Federalist judges during Adams' administration would seem to be an amazing exhibition of headlong and reckless partisanship, if not viewed in the light of their ideas of constitutional privilege and duty. They were trying to uphold the traditional ideal of government. They let no opportunity pass of instructing the people how monstrous and horrid a thing it was for them to rebel against magisterial control and disturb the conditional balance of power among the departments of government by seditious attempts to interfere in the administration of public affairs. The charges to a grand jury at times became a political harangue. In western Pennsylvania, Judge Addison, of the State judiciary, delivered a series of charges on Jealousy of the Administration and Government, the Horrors of Revolution, etc., pointing out to the people 
what terrible things were likely to happen if they were not dutiful in their behavior towards constituted authority." "91 Ellsworth, who had succeeded Jay as chief justice of the supreme court, expressed great admiration for these addresses and wrote Secretary Pickering: "I thank you for sending me the charge of that painstaking Judge Addison, who seems to be a light shining in darkness, though the darkness comprehends him not.",92 A little later Ellsworth himself denounced Jefferson and the whole Republican party as "apostles of atheism and anarchy, bloodshed and plunder."

In the elections of 1800 the Federalists were defeated in both the legislative and executive departments of the national government but to retain their control of the judiciary they determined to fill the courts with partisan appointees. To that end an act was passed on February 13, 1801, altering the judiciary system by the reduction of the supreme court, after a vacancy should occur, to five justices, the creation of sixteen new

91 Ford: Rise and Growth of American Politics, p. 112.

92 Flanders: Lives of the Chief Justices, ii, p. 193.

93 Ford: p. 113. 
judgeships for the establishment of a series of circuit courts, and the abolition of the district courts for Tennessee and Kentucky, the business of which was transferred to the new circuit courts. ${ }^{94}$ By this arrangement the entire judiciary system remained in the hands of the Federalists when the Jefferson administration came into power.

Republican hostility against the judiciary was at once aroused and the question of judicial tenure came to the front as a vital issue of the day. Jefferson had criticised the judiciary when, in the enforcement of the sedition act, they had punished Matthew Lyon for his attacks upon the Adams administration. At that time he wrote: "I know not which mortifies me most, that I should have to write what I think, or that my country bear such a state of things. Yet Lyon's judges, and a jury of all nations are objects of rational fear." ${ }^{95}$ He now became an active participant in a movement which had as its object the destruction of the constitutional guarantees which surrounded the judiciary and the removal from office of all those judges

94 Annals, 6th Cong., p. 1534.

95 Jefferson MSS., Nov. 26, 1798. 
who differed from him and his party in politics. Within a year the Republicans had secured the repeal of the judiciary act of 1801, legislating out of office all the judges created by that act. Beginning in Pennsylvania in the impeachment and removal of Judge Addison and the attempted impeachment and removal of the entire supreme court of the State, a movement spread to secure the removal by the same means of the Federalist judges in the courts of the United States. Although successful in securing the removal of Judge Pickering of the district court for New Hampshire, the Republicans were decisively defeated in their career of "judge breaking" in their failure to convict Associate Justice Chase of the supreme court of the United States and the movement came to an abrupt close.

The federal judiciary emerged from these attacks secure in the independence of their functions and the tenure of their offices. As a result of the decision in Marbury v. Madison and the acceptance of the doctrine of judicial review as part of the constitutional law of the various States it became a settled principle that the courts not the legislature should 
draw the line separating the functions of the three departments of government. And in the reaction following the acquittal of Justice Chase it became apparent that never again would Congress begin a systematic attack upon the judges from partisan motives. 


\section{CHAPTER II \\ CONGRESS AND THE INFERIOR COURTS}

The discretionary power vested in Congress "to ordain and establish inferior courts of the United States" became the subject of debate in the first Congress and the extent of this power has been a controverted point since 1801. The establishment of inferior federal courts was strenuously opposed by the States' rights element who thought that the State courts ought to be left to decide all cases in the first instance. ${ }^{1}$ In the Senate, Pierce Butler made a "flaming speech" against the judiciary act of 1789 and Richard Henry Lee sought to have the jurisdiction of the federal courts limited to admiralty and maritime cases. ${ }^{2}$ But the act was carried by the majority view that "if we have a government pervading the Union, we must have a judicial power of similar magnitude; we must

1 Annals, 1st Cong., p. 827.

2 Maclay: Journal, pp. 74, 85. 


\section{JUDICIAL TENURE IN}

establish courts in different parts of the Union.",

Likewise the independence of the judges was a principle at this time well understood by members of Congress to extend to the inferior courts. Mr. Smith, of South Carolina, pointed out that it would not be easy to alter the system when once established. "The judges," he said, "are to hold their commissions during good behavior, and after they are appointed they are removable only by impeachment; in consequence the system must be a permanent one.", Madison rested his objection to vesting the State courts with jurisdiction over federal cases on the ground that, in many States, the judges were "so dependent on the State legislatures that to make the Federal laws dependent on them would throw us back into all the embarrassments that characterized our former situation. He did not see how it could be made compatible with the Constitution, or safe to the Federal interests, to make a transfer of the Federal jurisdiction to the State courts."

3 Annals, 1st Cong., p. 860.

4 Ibid., p. 828.

5 Ibid., p. 813. 
Although the opponents of the inferior federal courts were defeated, the slow development of the federal judiciary during the first decade of its existence indicated a marked distrust on the part of the vast body of the people toward this new institution. The first United States circuit courts were attended with little business and the first two sessions of the supreme court saw presented but three cases, and, either for want of business or of a quorum, the court adjourned from day to day. When the courts did begin to exercise authority in the enforcement of the alien and sedition acts, States' rights sentiment blazed forth in the Virginia and Kentucky resolutions of 1798 and 1799 and the federal judiciary again became the target of attack.

\section{I}

Congress had made no move to interfere with the federal judiciary, and the first change in the system as organized by the act of 1789 came in the act of 1801, which placed in office a number of Federalist judges after that party had been defeated in the other departments of government. The intent of the 
framers of the judiciary act of 1801 has been to the present day a matter of some doubt. On the one hand it has been shown that alterations in the judiciary system of the United States had long been agitated before the failure of the Federalist party in the elections of $1800{ }^{6}$ Soon after the establishment of federal courts in 1789 relief had been sought by the justices of the supreme court from the arduous duties necessitated in riding the circuits. ${ }^{7}$ In 1799 a bill designed to establish a system of circuit courts was reported upon which action was postponed. But this later became the basis for the act of 1801. ${ }^{8}$ It has, therefore, been contended that, quite apart from the political advantage given the Federalists by the passage of the act of 1801, such changes in the judiciary system were warranted by necessity.

At the same time it is equally clear that the amount of business before the courts of the United States, although it had been excessive, had begun to decline. No further prosecutions were to be expected under the

6 See Farrand: Ameriean Historical Review, v, p. 682.

7 American State Papers, Misc., i, pp. 51-52.

8 Annals, 7th Cong., 1st Sess., p. 672. 
alien and sedition acts, and a decrease in the number of suits before the federal courts involving other questions was observed even before the accession of Jefferson to the presidency. ${ }^{9}$ Although the expense involved in the creation of the sixteen additional judgeships was grossly overestimated at the time, ${ }^{10}$ it cannot be doubted that the Republicans with their avowed policy of retrenchment had solid ground for feeling that these changes in the judiciary burdened the nation with an unnecessary expenditure. ${ }^{11}$

But what aroused the bitterest hostility among the Republicans was the partisan character of the appointments made by President Adams to the newly created offices. Nominated and confirmed during the last hours of his administration, every officer was a staunch Federalist and thoroughly wanting in sympathy with the new party which was so soon to come into power. A constitutional prohibition prevented the President from re-

9 American State Papers, Misc., i, p. 319 et seq.

10 In the debates on the repeal of the act of 1801 the Republicans claimed the expense of the new courts to be $\$ 137,000$. Professor Farrand estimates the expense at not more than $\$ 50,000$. American Historical Review, v, p. 685 . 11 Annals, 7th Cong., 1st Sess., p. 26. 
warding his friends in Congress with places upon the new circuit courts. ${ }^{12}$ But places were found for Richard Bassett, who as a presidential elector in 1797 had voted for Adams, and for Jeremiah Smith, who had distinguished himself during the two administrations of Washington by his unwavering loyalty in the support of all Federalist measures before Congress. Charles Lee, Adams' attorney general, and Oliver Wolcott, who succeeded Hamilton as secretary of the treasury and won the undying enmity of the Republicans by his conduct of that office, were similarly rewarded. Jared Ingersoll and Philip Barton Key, ardent Federalist partisans, were also commissioned. ${ }^{13}$

Other appointments to the circuit courts were for the most part made by promotion from the district courts. To the vacancies created in these courts President Adams followed the same policy of appointing loyal Federalists. Elijah Paine and Ray Greene, members of the United States Senate, and William H. Hill and Jacob Read, members of the House of Representatives, left Con12 Art. I, Sec. 4.

13 Executive Journal (1789-1805), pp. 381, 383. 
gress to receive places on the district courts. Harrison Gray Otis and John Wilkes Kittera, able advocates of Federalist policies in the House of Representatives, departed at the same time, carrying with them commissions to United States district attorneyships. ${ }^{14}$ It is not surprising, therefore, that factional feeling among the Republicans ran high and severe criticism was meted out to the courts.

But whether the "act to provide for the more convenient organization of the courts of the United States" was the result of a partisan attempt of the Federalists to retain a hold on the national government after they had been defeated in the elections of 1800 may or may not be true. The fact is that by a large group the changes were believed to be of this character. A letter of Stevens Thomson Mason, a close friend of Thomas Jefferson, declares that "a new judiciary system has been adopted with a view to make permanent provision for such of the Federalists and Tories as cannot hope to continue in office under the new administration." ${ }^{15}$

14 Executive Journal (1789-1805), pp. 384-385.

15 Breckinridge MSS., Feb. (19), 1801. The collection 
II

The Republican hostility to the judiciary was greatly increased and, led by the extreme States' rights advocates, a concerted action was planned by the Jefferson administration to undo the work of their predecessors. How this was to be done occasioned much concern, since the independence of the judiciary was a principle recognized by Republicans and Federalists alike. The question was raised by William Branch Giles in March, 1801, in a letter to Jefferson when he suggested that "a pretty general purgation of office has been one of the benefits expected by the new order of things." But the difficulties in the way of any sweeping changes in the judiciary he recognized by the admission that "the only check upon the judiciary system as it is now organized and filled is the removal of all its executive officers indiscriminately." ${ }^{16}$ Jefferson seems to have been satisfied that this was as far as they could go without exceeding the of the Breckinridge family papers in the Library of Congress has not yet been opened to the public. I am indebted to Miss Sophonisba Breckinridge for permission to make use of these unusually valuable MSS.

16 Jefferson MSS., March 16, 1801. 
limits of their authority, and replied to Giles that "the courts being so decidedly Federal and irremovable, it is believed that Republican attorneys and marshals, being the doors of entrance to the courts, are indispensably necessary to the Republican part of our fellow citizens, which is the main body of our people." 117

But the removal of the executive officers of the courts was of little avail so long as the judges remained, and by June the actual invasion of the judiciary was suggested. Then Giles came to the conclusion that "no remedy is competent to redress the evil but an absolute repeal of the whole judiciary system terminating the present offices and creating an entire new system, defining the common law doctrine, and restraining to the proper constitutional extent the jurisdiction of the courts." "18

While the federal judiciary system was under discussion by the friends of the administration at Washington, it also became the target of an assault in Kentucky. In that State the people had just completed the or17 Jefferson MSS., March 23, 1801.

18 Tbid., June 1, 1801. 
ganization of a judiciary system and feared the interference of the new circuit courts with the jurisdiction of their State tribunals. Long before the message of President Jefferson in which he suggested that Congress give attention to the judiciary system, John Breckinridge had been the recipient of numerous letters from his constituents urging that he strive for the repeal of the act of 1801. One such writer declared:

There is no act of the former Congress that in my opinion will work more subtle or certain mischief than that of extending their courts, - as its tendency will be to disunite the people and to wean their affections for their State governments. In Kentucky it will operate more mischievously than anywhere else, by jeopardizing those principles upon which our courts have hitherto proceeded in settling their land controversies. I much hope this law will be repealed or so much altered that we may feel easy under it. With the other excrescences of aristocratic legislation these additional judges may be left to graze in their own pastures. ${ }^{19}$

To the support of the Republicans in their partisan attack on the Federalists in the judiciary came the States' rights element. The 19 Breckinridge MSS., Nov. 21, 1801. 
controversy which had raged over the establishment of inferior federal courts in the convention of 1787 and in the first Congress was reopened. Not only the repeal of the obnoxious act of 1801 was demanded, but many wished to have the jurisdiction of the federal courts curtailed and the inferior courts abolished entirely. Senator Breckinridge was urged to "go farther and make such a change in the Constitution as to limit the jurisdiction of the Federal courts to courts of admiralty and cases arising under the Constitution.', If this could not be done, he was asked to "have it done away with in the State of Kentucky.' His constituents pointed out that Kentucky was so remote from the Atlantic and had interests so distinct from the eastern section of the country that the exercise of authority by the federal courts interfered materially with their welfare. ${ }^{20}$

Breckinridge was not long in making up his mind to lead the movement for the repeal of the unpopular law. About the time the first message of President Jefferson was read in Congress he wrote to John Taylor of Caroline asking his views on the judicial system, 20 Breckinridge MSS., Feb. 22, 1802. 
and requesting some suggestions as to how a revision might be brought about. In reply Taylor wrote a long academic argument which became the basis of the Republican attack in the debates in Congress on the repeal. $\mathrm{He}$ considered that the question possessed two phases: first, whether the office should continue; and second, whether the officer should continue after the office had been abolished as being unnecessary. As to the first, he said:

Congress are empowered from time to time to ordain and establish inferior courts. The law for establishing the present inferior courts is a legislative instruction affirming that, under this clause, Congress may abolish as well as create these judicial offices; because it does expressly abolish the then existing courts for the purpose of making way for the present. ${ }^{21}$

It is probable that this construction is correct, but it is equally pertinent to our object whether it is or not. If it is, then the present inferior courts may be abolished as constitutionally as the last; if it is not, then the law for abolishing the former and establishing the present was unconstitutional, and being so, is undoubtedly repealable. Thus the

21 Although the act of 1801 abolished the district courts in Kentucky and Tennessee the judges were retained in the new circuit courts. 
only ground which the present inferior courts can take is that Congress may from time to time create, regulate, or abolish such courts as the public interest dictate, because such is the very tenure under which they exist. ${ }^{22}$

The tenure of the judges whose courts had been abolished by the act of 1801 had not been abridged, but it would be little suited to the purposes of Breckinridge and his partisans if they, after abolishing the circuit courts, were obliged to create new courts for the sixteen judges whose offices had been destroyed. Taylor, therefore, in the second part of his argument, sought to point out a way by which the commissions might be destroyed as well as the offices. He said:

The Constitution declares that the judge shall hold his office during good behavior. Could it mean that he should hold this office after it was abolished? Could it mean that his tenure should be limited by behaving well in an office which did not exist? It must either have intended these absurdities or admit of a construction which will avoid them. This construction obviously is that an officer should hold that which he might hold, namely an existing office, so long as he did that 22 Breckinridge MSS., Dec. 22, 1801. 
which he might do, namely his duty in that office; and not that he should hold an office which did not exist or perform duties not sanctioned by law. If, therefore, Congress can abolish the courts, as they did by the last law, the officer dies with the office, unless you allow the Constitution to admit impossibilities as well as absurdities.

Moreover the salary is to be paid during their continuance in office. This limitation of salary is perfectly clear and distinct. It literally excludes the idea of paying a salary when the officer is not in office; and it is undeniably certain that he cannot be in office when there is no office. There must have been some other mode by which the officer should cease to be in office than that of bad behavior, because if this had not been the case the Constitution would have directed that the judges should hold their offices and salaries during their good behavior, instead of directing that they should hold their salaries during their continuance in office. This could only be an abolition of the office itself by which the salary would cease with the office although the judge might have conducted himself unexceptionably. This construction certainly coincides with the public opinion and the principles of the Constitution. By neither is the idea tolerated of maintaining burthensome sinecure offices to enrich unfruitful individuals.

Nor is it incompatible with the good behavior 
tenure when its origin is considered. It was invented in England to counteract the influence of the crown over the judges. And we have rushed into the principle with such precipitancy, in imitation of this our general prototype, as to have outstripped monarchists in our efforts to establish a judicial oligarchy; their judges being removable by a joint vote of Lords and Commons, and ours by no similar or easy process.

The tenure, however, is evidently bottomed on the idea of securing the honesty of judges while exercising the office, and not upon that of sustaining useless or pernicious offices for the sake of the judges. The regulation of offices in England, and indeed of inferior offices in most or all countries, depends upon the legislature; it is a part of the detail of government which necessarily devolves upon it, and is beyond the foresight of a constitution because it depends upon variable circumstances. And in England a regulation of the courts of justice was never supposed to be a violation of the good behavior tenure. If this principle should disable Congress from erecting tribunals which temporary circumstances might require, without entailing them upon the society after these circumstances by ceasing had converted them into grievances, it would be used in a mode contemplated neither in its original or duplicate.

Whether courts are erected by a regard to the 
administration of justice or with the purpose of rewarding a meritorious faction, the legislature may certainly abolish them without infringing the Constitution whenever they are not required by the administration of justice, or the merit of the faction is exploded and their claim to reward disallowed. ${ }^{23}$

Breckinridge, in moving the repeal of the act of 1801 on January 6, 1802, took the ground that the changes made in the judiciary were unnecessary and improper in that they had increased the number of federal judges at a time when the amount of business pending before the courts of the United States was steadily declining. Following the argument of Taylor, and in many points using the identical words of the latter, he strove to show the power of Congress to put down the additional courts together with their judges. ${ }^{24}$ He accepted the construction laid down by Taylor that the act of 1801 was "a legislative construction", of the power of Congress "from time to time, to ordain and establish inferior courts," giving to Congress the power to abolish as well as to create inferior

23 Breckinridge MSS., Dec. 22, 1801.

24 Annals, 7th Cong., 1st Sess., p. 26. 
courts, because the two districts were abolished by the twenty-seventh section of that act. But independent of this legislative construction, he insisted that it would be a paradox in legislation to say that the legislature in one Congress has a discretionary power to establish inferior courts and yet be restrained from abolishing them in a subsequent Congress of equal authority.

With respect to the judges he was equally certain that they must cease to be in office when the repeal of the act was accomplished. The constitutional guarantees, he thought, protected them against removal by the executive or diminution of their salaries by the legislature but never contemplated the possibility of their surviving the destruction of their offices. This would be to create a group of "nondescripts" unacknowledged by either the letter or the spirit of the Constitution. ${ }^{25}$

The Republicans at once assumed the ground that the inferior courts are the creatures of the legislature. "I observe," said Stevens Thomson Mason, "a clear distinction between the Supreme Court and the other courts. With regard to the institution of the 25 Annals, 7th Cong., 1st Sess., p. 29. 
Supreme Court the words of the Constitution are imperative; while with regard to the inferior courts they are discretionary." From the language of the Constitution he thought that no other view could be taken than that "the Legislature should have power, from time to time, to create, to annul, or to modify the courts as the public good might require, whenever a change of circumstances may suggest the propriety of a different organization." ${ }^{26}$

The existence of certain constitutional guarantees protecting the judges he admitted, but thought they amounted to this: "That, unlike other officers appointed by the President, judges shall not be removed by him; that their salaries shall not be diminished by the legislature; and that while the legislature may continue any particular judicial establishment under which a judge is appointed, he shall hold that appointment in defiance of both the other departments of government." Any other construction he thought would render the judges independent of the nation itself. ${ }^{27}$

26 Annals, 7th Cong., 1st Sess., p. 60.

27 Ibid., p. 64. 
The control given the legislature over the inferior courts it was held undoubtedly vested in Congress a power of removal. Senator Stone went so far as to declare that not only could courts be abolished by the repeal of the legislative enactments creating them, but Congress might indeed remove a judge without discontinuing his office. This radical position did not find favor even among the Republicans and was repeatedly disavowed by other members of the party. But Senator Stone contended that although misbehavior is not an impeachable offense yet it is the ground upon which the judges are to be removed from office, wherefore "the process of impeachment cannot be the only one by which judges may be removed from office, under, and according to the Constitution." $\mathrm{He}$ thought it "to be a thing undeniable, that there resides somewhere in the government a power to declare what shall amount to misbehavior in office by the judges, and to remove them from office for the same, without impeachment.",28

But from the Federalist ranks Gouverneur Morris rose and denied that the people had 28 Annals, 7th Cong., 1st Sess., p. 72. 
vested all powers in the legislature. On the contrary, he said, they had "vested in the judges a check intended to be efficient-a check of the first necessity, to prevent an invasion of the Constitution by unconstitutional laws-a check which might prevent any faction from intimidating or annihilating the tribunals themselves." ${ }^{29} \mathrm{He}$ answered $\mathrm{Mr}$. Stone by pointing out that in our law misbehavior is not known but must be expressed by the term misdemeanor which is embraced within the constitutional provision. That Congress could assume any right from the deficiency of the Constitution in this respect he denied..$^{30}$

The argument of the Republicans that the act of 1801 was unconstitutional in abolishing the district courts of Kentucky and Tennessee, Morris showed to be unsound. "If the law is unconstitutional," he said, "why repeal? In this case no repeal can be necessary; the law is in itself void; it is a mere dead letter." "31 But the power to declare such an act invalid rests with the judiciary,

29 Annals, 7th Cong., 1st Sess., p. 38.

30 Ibid., p. 90.

31 Ibid., p. 81. 
and it was for this reason that Jonathan Mason urged the necessity for the independence of the judges "because the duties which they have to perform call upon them to expound not only the laws but the Constitution also; in which is involved the power of checking the Legislature in case it should pass any laws in violation of the Constitution. For this reason it was important that the judges should be placed beyond the control of the Legislature." ${ }^{32}$

Breckinridge, in alarm at the turn the debate was taking, made a complete denial of the power of the courts to review acts of the legislature. No such power, he insisted, was granted by the Constitution, and the legislature have an equal right of interpretation with the courts; therefore "the Legislature have the exclusive right to interpret the Constitution in what regards the law-making power, and the judges are bound to execute the laws they make." ${ }^{33}$ Scarcely had he finished when Gouverneur Morris was on his feet demanding to know

32 Annals, 7th Cong., 1st Sess., p. 32.

83 Ibid., p. 179. 
If gentlemen are prepared to establish one consolidated government over this country? All the arguments they have used in this debate went to that conclusion. The power of the courts to decide upon the constitutionality of laws is derived from authority higher than the Constitution; it is derived from the constitution of man, from the nature of things, from the necessary progress of human affairs. But the last member up has told us that the legislature may decide exclusively on the Constitution, and that judges are bound to execute the laws which the legislature enact. If this doctrine be sustained, what possible mode is there to avoid the conclusion that the moment the legislature of the Union declare themselves supreme, they become so? The sovereignty of America will no longer reside in the people, but in Congress, and the Constitution is whatever they choose to make it.

If America should be brought under one consolidated government, it could not continue to be a republic. If the States be destroyed, we must become the subjects of despotism. Are the gentlemen ready to prostrate that sovereignty at the feet of the general government ? $^{34}$

That these radical States' rights men had any intention of strengthening the national ${ }_{34}$ Annals, 7th Cong., 1st Sess., pp. 180-181. 
government at the expense of the States could not for a moment be supposed. But the argument of Gouverneur Morris left them as the only alternative the bald admission that partisan motives alone formed the basis for their measure.

The independence of the judiciary was wholly denied by Giles when the subject came up for debate in the House of Representatives. He had been one of the first to urge the repeal as a means of ousting from the national government his political opponents, ${ }^{35}$ and he now sought to show that

The term independence of judges or of the judiciary department was not to be found in the Constitution but was a mere inference from some of the specified powers. The Constitution only declared that there should be such a department formed by the other two departments who owe a responsibility to the people. The only limitation upon the power of Congress consists in the number of supreme courts to be established, and the spirit, as well as the words of the Constitution, are completely satisfied provided one Supreme Court be established. He therefore felt the firmest convic35 Supra, p. 59 , 
tion that there was no constitutional impediment in the way of repealing the act in question. ${ }^{36}$

But this view was not generally sustained by the other Republicans, and John Randolph sought to "rescue from misrepresentation" the position to which Giles had carried the debate. He agreed that "the Constitution is a limited grant of power, and that none of its general phrases are to be construed into an extension of that grant," and continued:

I am free to declare that if the intent of this bill is to get rid of the judges, it is a perversion of your power to a base purpose; it is an unconstitutional act. If, on the contrary, it aims not at the displacing one set of men, from whom you differ in political opinion, with a view to introducing others, but at the general good by abolishing useless offices, it is a constitutional act. ${ }^{37}$

On the other hand, in both the House and Senate the Federalists contended that the tenure of the judges "is not derived from the laws but from the Constitution,",38 and "that the moment the judge is appointed, the office is ingrafted in, and becomes a part of the

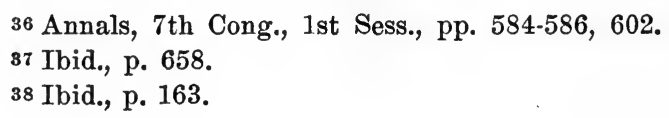


Constitution, and cannot be taken away without impairing the Constitution itself." ${ }^{39}$ But they admitted a distinction between the office and the officer, and held that to abolish an office and to remove an officer were quite distinct acts. As was pointed out by Mr. Goddard,

The abolition of a court does not necessarily imply that a judge is put out of office, or the office itself discontinued. Congress by law may erect courts and create offices but justice cannot be administered in them until afterwards, by an act of the President, judges are appointed. But the legislature must do all that is done on this subject with an eye to the independence of the judges already in office. ${ }^{40}$

Although the repeal was carried, the vote was along partisan lines and occasioned the Republicans much concern lest the supreme court should declare the act unconstitutional. Breckinridge, although he later denied the power of the courts to review acts of Congress, had at the beginning of the debate declared that "if the judges are entitled to their salaries under the Constitution, our re39 Annals, 7th Cong., 1st Sess., p. 541.

40 Ibid., p. 731. 
peal will not affect them; and they will, no doubt, resort to their proper remedy.", Thereafter an appeal to the courts by the deposed judges had been in the minds of all. To prevent such action the next session of the supreme court was set for February, 1803, the August term being omitted in 1802. This was denounced by James A. Bayard, the leader of the Federalists in the House, as "a patchwork designed to cover one object,the postponement of the next session of the Supreme Court ... to give the repealing act its full effect before the judges are allowed to assemble." ${ }^{42}$

Denied a judicial review of the act depriving them of their offices, the judges of the circuit courts forwarded a petition to Congress in which they represented "that the rights secured to them by the Constitution, as members of the judicial department, had been impaired," and asking that the case be submitted to judicial determination. The Senate declined to consider the petition, while a proposition to submit the matter to the courts for decision was defeated in the House.

41 Annals, 7th Cong., 1st Sess., p. 30.

42 Hamilton MSS., Apr. 12, 1802. 
Here it was held that the right to abolish inferior courts rested with Congress and that the judges were entitled to compensation only for services rendered. ${ }^{43}$

It is superfluous to point out that the importance of the repeal of the act of 1801 lay in the fact that the final determination of the right to abolish inferior courts and to deprive the incumbents thereof of their commissions fell to Congress. No opportunity being given the judiciary to interpret the Constitution with respect to this power, there was no means of challenging the validity of the measure in the way customary in our government. Congress was, therefore, free to claim that a precedent had been set which should determine future action in dealing with the judiciary.

Although the Republicans hailed with delight the death of "Poor Jude," as they called the act of 1801, and asserted the propriety of the means adopted to secure the repeal, Congress has not followed the precedent thus established. The repealing act, in so far as it deprived the judges of their commissions, has been condemned by the leading commen43 Annals, 7th Cong., 2d Sess., pp. 427-441. 
tators on the Constitution. Story declared that "the measure, if its constitutionality can be successfully vindicated, prostrates in the dust the independence of all inferior judges, both as to the tenure of their offices and their compensation for services, and leaves the Constitution a miserable and vain delusion." ${ }_{44}$ But Congress has in every subsequent alteration of the federal judiciary respected the tenure of the judges of the courts abolished. Nor has any attempt been made by Congress to deprive judges of the inferior courts of their commissions, except in the recent action in abolishing the United States Commerce Court.

\section{III}

In many ways the movement for the abolition of the United States Commerce Court in 1912 and 1913 was analogous to the repeal carried by the Jefferson administration. In the first place, there was far less popular demand for the establishment of a commerce court than arose for the creation of circuit courts in 1801. Both institutions were regarded by their opponents as unnecessary

44 Story on the Constitution, 4th ed., ii, pp. 427-429. 
and expensive. Indeed, the commerce court owed its existence solely to the perseverance of President Taft and his administration. Their unremitting efforts to secure the passage of the bill amending the interstate commerce act in 1910 alone prevented the movement for the creation of the new court from being sidetracked.

In other respects the situation differed markedly from that of 1802 . When the behavior of the commerce court first came up for consideration in Congress, it became apparent that the arguments against the tribunal went to the question of the fitness of the judges rather than to the theory of the court. Charges of pro-railroad leanings on the part of the judges of the commerce court began to be whispered about. These may have gained substantial ground from the report of the interstate commerce commission, where it was pointed out that "out of 27 cases passed upon by the commerce court, preliminary restraining orders or final decrees have been issued in favor of the railroads in all but seven cases, and of these only three are of any magnitude." ${ }^{45}$ At about the same time 45 I. C. C. Report, 1911, p. 59. 
evidence was presented resulting in the impeachment of Judge Archbald, one of the members of the court. It followed, therefore, that in addition to the objections that the commerce court was unnecessary and unduly expensive, the discussion in the House of Representatives assumed that the tribunal was created to give the railroads an advantage and the judges were not impartial. ${ }^{46}$

The establishment of the United States Commerce Court in 1910 came as a result of attempts to expedite the hearings of appeals from decisions of the interstate commerce commission under the Hepburn amendment to the act to regulate commerce. That amendment, passed in 1906, gave to the interstate commerce commission power to establish a rate for the future. Prior to this time the commission was an administrative or quasi judicial body, but now it became endowed with legislative functions. ${ }^{47}$ At the same time it was the constitutional right of every carrier affected by an order of the interstate commerce commission to appeal to 46 Traffic World, ix, p. 1015.

47 Hearings on the Legislative, Executive, and Judicial Appropriation Bill, 1914. 
a court to protect it from the enforcement of the order establishing such rate, where it might appear from the presentation of the facts by the carrier that the effect of the order would be to deprive it of a reasonable return upon its invested capital, and, therefore, to amount to a taking of property without due process of law, contrary to the provisions of the fifth and fourteenth amendments of the Constitution, or unjustly to discriminate against the carrier (Smythe v. Ames, 169 U. S.). Since this right might be exercised in any one of the courts of the United States, it was thought that not only did much delay result in the final observance of the orders of the commission, but considerable contrariety of decision, with resulting uncertainty in the law. To obviate this condition it was decided to concentrate the judicial review of the orders of the commission in one court, and the commerce court of the United States was thereupon created.

The orders of the interstate commerce commission are in form either: (a). those granting relief, requiring a carrier to cease and desist from charging a particular rate or continuing a particular practice, and pre- 
scribing another and less rate or a different practice; or (b) those denying relief, as dismissing a formal complaint in which has been alleged the unreasonableness of a rate or practice. Orders of the first type have been called "positive," those of the second "negative," orders.

The act creating the United States Commerce Court, among other powers delegated, gave them jurisdiction over proceedings "to enjoin, set aside, annul, suspend in whole or in part, any order of the interstate commerce commission." ${ }_{48}$ The language of the section would indicate that the court might enjoin "any order of the interstate commerce commission" which they might think inequitable or unjust, or which they might disapprove on any other ground. But the supreme court, beginning with the case of the Abilene Cotton Oil Company (204 U. S.), down through a long series of decisions, practically declared that the courts have no right to interfere with the exercise by the commission of the powers conferred upon it by Congress, so long as the commission does not overstep the limits of its jurisdiction. It was therefore 48 Sect. I. 
provided that the commerce court "shall have the jurisdiction now possessed by the circuit courts of the United States and the judges thereof"' in the class of cases specified. ${ }^{49}$

That the commerce court might by reason of this jurisdiction take cognizance of appeals against the enforcement of "positive" orders of the commission was plain. The act of June 29, 1909 (34 Stat. L., 584), made the orders of the commission self-executing or self-enforcing. The failure, neglect, or refusal to obey them within the time limit thereof was made punishable by heavy penalties. A method for annulling them, inasmuch as the commission was not a court, was under the Constitution necessary. He against whom the order ran was entitled to his day in court. The interests of the carrier were safeguarded. But it is to the interest of the shipper that opportunity be given for the judicial review of the "negative" orders of the commission, and it was in the attempt to enlarge its jurisdiction so that it might consider appeals from the shipper who had been 49 Sect. I. 
denied relief that the commerce court met its doom.

The great case in which a shipper denied relief at the hands of the interstate commerce commission sought redress from the commerce court was that of the Procter and Gamble Company v. United States. The facts showed that on February 25, 1910, the Cincinnati, Hamilton and Dayton Railway Company and other carriers had filed with the commission separate tariffs all charging demurrage on private cars whether on their own or on private tracks. The justice of this ruling is patent, as otherwise the way would have been open for collusion between the railroads and big shippers and great injury might have resulted to the smaller shipper unable to provide himself with private cars. But the Procter and Gamble Company complained that the rule was unjust and unreasonable in that it deprived them of the right to use their private tank cars upon private tracks for their own purposes without paying demurrage charges, although the cars had been delivered to them and had ceased to be engaged in railroad service but still retained their cargo. 
The interstate commerce commission dismissed the complaint and the Procter and Gamble Company appealed to the commerce court. Their contention was opposed by the government on two grounds: first, that the commerce court had no jurisdiction to annul a "negative" order of the commission; and, second, that the order was a proper one. The commerce court held that it had jurisdiction to hear the appeal, but that the decision of the commission was fair. ${ }^{50}$ When the case was carried to the United States Supreme Court, however, that tribunal held that it need not pass on the legality of the order of the commission since under the law as it now stood, the commerce court had no jurisdiction to hear an appeal by a shipper to whom the commission had denied relief. ${ }^{51}$ Under the doctrine laid down in this case, the supreme court dismissed the appeal in two similar cases, Hooker v. Knapp and the Eagle White Lead Company v. Interstate Commerce Commission. ${ }^{52} \mathrm{By}$ reason of the same decision the commerce court was so Commerce Court Cases, No. 9.

51225 U. S. 282.

52 Ibid., 302. 
obliged to dismiss nine cases for want of jurisdiction..$^{53}$

The twelve cases thus dismissed constituted one-sixth of all the cases filed in or transferred to the commerce court. The elimination of this great number of cases from the docket and the limitation of its jurisdiction to appeals from "positive" orders of the commission raised grave doubts as to the usefulness of such a tribunal.

While this phase of the question was under discussion, evidence was presented against Judge Archbald which, if proved, would indicate that not only was this member of the court pro-railroad in his attitude but guilty of such judicial misconduct as has seldom characterized any federal judge. ${ }^{54}$ This unquestionably brought upon the entire commerce court the stigma of disrepute and contributed to increase its unpopularity throughout the country. Memorials were received in Congress from the Nevada Railroad Commission urging the abolition of the tribunal as an unnecessary institution while the State legislature of Arizona expressed the belief ${ }^{53}$ Commerce Court Cases, p. 50.

54 Infra, p. 145. 
that "the court was being used by the railroad corporations for the purpose of blocking the work of the interstate commerce commission." ${ }_{55}$

Of course, it was within the power of Congress to enlarge the scope of the authority of the commerce court by giving to it jurisdiction over appeals by the shipper as well as by the carrier. This was suggested in an amendment in 1912 wherein it was proposed to include within the power of the commerce court jurisdiction "to review, in the same manner as in cases wherein affirmative orders have been made, all errors of law in cases wherein the Interstate Commerce Commission has made a final refusal to grant, in whole or in part, the relief sought in any proceeding before it." ${ }^{56}$ Thus while the court would have had no authority to review the findings of fact established by the commission, it would in all cases have had the power to mark out the law as applied to particular facts and to certify the law in the case to the commission for its guidance in further proceedings. But such was the feel55 Cong. Record, 62d Cong., 2d Sess., pp. 450, 6993. 58 62d Cong., 2d Sess., H. Rep. 1012. 
ing with regard to the tribunal that any proposition to increase its power received scant consideration.

The movement to abolish the commerce court met with success in the House of Representatives, but when the measure was submitted to the Senate a sharp contest was precipitated over the clause providing for the destruction of the judgeships. This proposition was condemned by President Taft as scarcely less objectionable as a means of abridging the judicial tenure of office than the popular recall. ${ }^{57}$ When the final conference agreement between the two houses was framed, although it definitely abolished the commerce court, the judges were reassigned to service in the circuit courts, from which most of them had been drawn. But the project was frustrated by the veto of President Taft, who came to the defence of the court maintaining that it was a necessary institution and one calculated to expedite business. ${ }^{58}$

Hostility to the judges of the commerce court subsided no less than the determination to destroy the tribunal itself. When in the 57 Cong. Record, 62d Cong., 2d Sess., p. 11900.

58 Ibid., p. 11908. 
autumn of 1913 the abolishment of the court was again brought forward in Congress as a "rider" to the urgent deficiency bill, an amendment was early added depriving its four remaining judges of their commissions. ${ }^{59}$ Little opposition to the proposition to abolish the judgeships was encountered in the House of Representatives, but in the Senate a debate on the subject scarcely less notable than that of 1802 arose.

The arguments in the Senate debate quickly turned upon the constitutional power of Congress to abridge the tenure of judges of the inferior courts commissioned to hold office during good behavior. It was pointed out by Mr. Lewis that the House had apparently expressed the wish of the people in abolishing the court and it only remained for the Senate to settle what should be the disposition of the judges. ${ }^{60}$ Senator Nelson ably argued that since the act creating the commerce court provided for the appointment of five additional circuit judges who might,

59 Judge Archbald had been removed from office as a result of conviction by the Senate upon the articles of impeachment on January 13, 1913.

${ }^{60}$ Cong. Record, 62d Cong., 2d Sess., p. 5958. 
from time to time, be assigned to duty on this tribunal or upon the circuit courts at the discretion of the chief justice, the judges thus created were upon the same footing as other circuit judges. It might be proper for Congress to abolish the commerce court but the judges would nevertheless remain in the enjoyment of their commissions. ${ }^{61}$ This the bill recognized; and to secure the elimination of the judges as well as the annihilation of the court, he said, it had been necessary to include as a part of the measure the amendment proposed by Mr. Bartlett in the House.

The leading argument for the abolition of the judgeships was undertaken by Senator Hoke Smith, who followed quite closely the majority view in the debates of 1802 . He went even further, however, insisting that it was within the power of Congress to abolish particular offices thereby legislating out of office particular judges, whenever such legislation might be necessary, without abolishing the entire class of courts to which the particular one might belong. ${ }^{02}$ But a few welldirected questions from Senators Borah and ${ }^{61}$ Cong. Record, 62d Cong., 2d Sess., p. 5954. 62 Ibid., p. 5955. 
Shields shattered the arguments of Hoke Smith into fragments of absurdity. Mr. Shields brought out the fact that the judges were judges of the circuit courts and not of the commerce court, and asked if their tenure of office was in any way dependent upon the existence of the latter tribunal. Mr. Smith declared that it was not. "Then," said Mr. Shields, "is not a statute which removes them from office another mode of removing the judges when the Constitution provides that they can be removed only by impeachment?" ${ }_{63}$

Mr. Smith was no longer able to command serious consideration for his contention, and concluded by insisting that

There is nothing in the Constitution that limits the power of Congress to increase or decrease the number of judges of the inferior courts. I take issue with the proposition that having once increased their number they must remain increased during the life of the incumbents. ${ }^{6 t}$

To this Mr. Borah sarcastically rejoined:

The country will be glad to know, in view of this urgent propaganda for the recall of judges, that ${ }^{63}$ Cong. Record, 62d Cong., 2d Sess., p. 5956.

${ }^{64}$ Ibid., p. 5956. 
they need not wait for the slow process of impeachment or recall, but can call upon their Senators and Representatives to eliminate any man from the bench that they want off the bench. They can simply abolish his circuit, get him out, and recreate his circuit. ${ }^{65}$

It became apparent that while the Senate felt that the commerce court should be abolished, there was by no means a majority of the members who favored the destruction of the judgeships. Mr. Walsh thereupon came forward with an amendment providing that, although the court should no longer exist:

Nothing . . . shall be deemed to affect the tenure of any of the judges now acting as circuit judges by appointment under the terms of said act, but such judges shall continue to act under assignment as the said act provides, as judges of the district courts and circuit courts of appeals; and in the event of and on the death, resignation, or removal from office of any of such judges his office is hereby abolished and no successor to him shall be appointed. ${ }^{66}$

This proposition commanded great respect, being predicated on the theory that "although Congress has the power to abolish any

${ }_{65}$ Cong. Record, 62d Cong., 2d Sess., p. 5957.

${ }^{66}$ Ibid., p. 5958. 
court which it creates, it must do so in subordination to the other provision of the Constitution, which provides that the judges of the Supreme and the inferior courts as well shall hold their offices during good behavior."

Some further argument for the abolition of the judgeships was made by Senator Bacon on the ground that since these judges were not at the time of their appointment assigned to particular circuits but were in the nature of "floaters," an entirely new jurisdiction had been created, and that when that jurisdiction was itself abolished the judges would go with it. ${ }^{68}$ But although this line of argument was followed up by Hoke Smith, the sentiment of the majority of the members of the Senate was distinctly opposed to any such view.

The view which finally prevailed in the Senate was well stated in the closing hours of the debate by Mr. O'Gorman. After declaring that he entertained no doubt as to the existence of a power in Congress to abolish any inferior court and thereby legislate out ${ }^{67}$ Cong. Record, 62d Cong., 2d Sess., p. 5959. 68 Ibid., p. 5961. 
of office the judge presiding therein, he gave his support to the amendment proposed by Mr. Walsh, because he conceived

Of no greater injury that could be done to the judicial department of the country than to have it adopted as the policy of Congress to use this great constitutional prerogative as a substitute for impeachment. It would be very unfair . . . after four or five lawyers have accepted a commission from the President of the United States to take what they had a right to understand was a life position, subject to good behavior . . . that within a few years the Congress for the first time in 111 years should undertake to exercise a power confessedly used as a substitute for the impeachment process. If any of these judges have been found untrue or unworthy, we have a familiar procedure established by the Constitution for removing them. That they have not been guilty of offense justifying impeachment is clear from the circumstance that at no time has such a proceeding been threatened against them. ${ }^{69}$

\section{IV}

Whether Congress can be said to have abandoned as unsound the precedent of 1802 is difficult to determine. The hostility to the ${ }^{69}$ Cong. Record, 62d Cong., 2d Sess., p. 5973. 
judges of the commerce court, so apparent in the beginning, changed to a feeling of sympathy at the conclusion of the debates. Since most of the judges had reached their present positions because of promotions from the lower courts, it would be unjust, it was agreed, to sweep away the rewards of a lifetime of service upon the federal judiciary. At the same time an abundance of evidence was produced to show the need for these judges in a number of the circuit courts where the amount of business before the court threatened to overwhelm the judges already on the bench. But probably the most potent factor in determining the continuance of the judges was the attitude of the President. Mr. Taft in his turn gave unmistakable evidence of his feeling. While Mr. Wilson avoided all official utterance as to his view of the matter, it was understood that he was opposed to the proposition to abolish the judgeships and would resist any attempt on the part of Congress to carry it out. The reception accorded the Senators who held to the construction laid down by the majority in 1802 would indicate that the precedent was not in high esteem. But in the absence of 
judicial decision on the point any future Congress is free to ignore the action of 1913 and to rehabilitate the construction of the Jeffersonian faction.

The distinction between the judicial office and the judge has received consideration in numerous cases before the courts. The power of Congress to determine the jurisdiction of the inferior courts has been universally admitted and has been granted by the United States Supreme Court. The court has declared that "Congress have constitutional authority to establish, from time to time, such inferior tribunals as they may think proper, and to transfer a cause from one such tribunal to another. In this last particular there are no words in the Constitution to prohibit or restrain the exercise of legislative power." 'That Congress has the power to abolish any inferior court after it has been created is by no means so well established. A decision of the United States District Court for Massachusetts in 1887 maintained that "the original jurisdiction of the Supreme Court of the United States is conferred by the Constitution, and Congress has no power 70 Stuart v. Laird, I Cranch 299. 
to enlarge or restrict it. But the jurisdiction of the inferior courts is derived from and is subject to the absolute control of Congress, and may be changed or taken away at pleasure. Existing courts may be abolished, and their jurisdiction, and all cases pending in them, whatever their condition, transferred to other existing courts, or to new courts." "r1

Nevertheless, it must be observed that Congress is obliged to make adequate provision for the judicial power. Since the defeat of the States' rights party in the debates on the judiciary act of 1789 , both in theory and practice, Congress has continued the design of a judiciary system commensurate to the other departments of government. Whenever courts have been abolished others have been established equally competent to the exercise of the judicial power. This has been the course of Congress as illustrated by the repealing act of 1802 which restored the courts as they had existed prior to February 13,1801 , and in the judiciary code of March 3,1911 , by which the circuit courts were abolished but the district courts at the same

71 United States v. Haynes, 29 Fed. Rep. 696. 
moment were equipped with equal competency to exercise the judicial power. ${ }^{72}$

Never has Congress, except in the heat of partisan conflict, invaded the independence of the federal judiciary to the extent of depriving judges of their commissions otherwise than by the constitutional procedure of impeachment. The single assertion by Congress of this power has been justly condemned as an encroachment upon the judicial power which is fraught with the greatest danger to this department of government. It is peculiarly unfortunate that no judicial settlement of this question has been attained. Nevertheless, Chief Justice Marshall in private commented upon the repealing act of 1802, considering it to be

Operative in depriving the judges of all power deprived under the act repealed. But the office remains which is a mere capacity, without a new appointment to receive and exercise any new judicial powers which the Legislature may confer. ${ }^{73}$

The reasonableness of this view cannot but be apparent. The creation of a judicial

72 For an interesting argument on this point, see $62 \mathrm{~d}$ Cong., 2d Sess., Senate Doc. 443.

73 Hamilton MSS., Apr. 25, 1802. 
branch of govermment is effected by the Constitution and the guarantees which shall secure its officers are set forth with equal precision. But the framers of our government well knew that they were unequal to the task of prescribing the tribunals through which the judicial power should function. It was recognized that changing circumstances would render unsafe any attempt to describe with a rigidity demanded by a written constitution a system of courts which should be unalterable. They wisely vested in Congress the power to erect from time to time as conditions might require inferior tribunals and gave to that body the authority to determine their jurisdiction.

The necessity which compelled this delegation of power it cannot be claimed enables Congress to encroach upon the constitutional prerogatives of the judiciary. That department is admitted to be a co-ordinate branch of the government. It stands upon the firm foundation of the Constitution and is in no way subject to control by Congress save as emergencies arise necessitating the creation of new courts or the alteration of those existing. Then Congress may, by appropriate 
legislation, satisfy the demands of circumstances, but only in subordination to such other clauses of the Constitution as safeguard the judicial branch of government. By no other view can Congress exercise its authority to deal with the inferior courts of the United States and at the same time comply with the imperative mandate of the Constitution that judges shall hold their offices during good behavior. 


\section{CHAPTER III}

\section{THE REMOVAL OF JUDGES}

In order that judicial misbehavior may be effectively dealt with a power of removal must exist somewhere, and to this end the framers of the federal Constitution seized upon the procedure of impeachment and conviction as the only remedy consistent with the necessary independence of the judges. The idea was borrowed directly from the revolutionary State constitutions where the form of removal on impeachment and conviction was in high favor. Nor is this strange when we consider how strongly the colonists had contended for the right of impeachment by their legislative assemblies. John Adams had insisted upon the power and practice of impeachment as essential to every free government. ${ }^{1}$ But the proprietary government of Pennsylvania seems to have been the only one in which impeachments were provided. ${ }^{2}$

1 Adams: Works, ix, pp. 236-241.

2 Poore: Charters and Constitutions, p. 1521. 
The charters of the other colonies were silent on the subjeet, while in the royal colonies the right hád: been expressly denied by the (rown. $\therefore 0^{3}:$ :

In numerou's conflicts with the home government the colonists were repeatedly defeated in their efforts to secure a power of removal in the hands of their assemblies. ${ }^{4}$ The question remained for the clash of arms to settle, but as the colonists prepared to separate from the mother country, one of the great injustices under which they felt they languished was the denial of the right to impeach and remove public officers whom they considered unfit. It is true that "the bad old days, when judges did the bidding of the King, were much more vivid to them than to us." It is true that "the fathers of some of these men-the grandfathers of all-could recall Jeffreys and the Bloody Assizes." But it was these men themselves who had clamored in vain for the right of impeachment before their colonial assemblies. What had happened under the last Stuart king was dimmed by long years; what they had sought

3 Foster on the Constitution, p. 634.

4 Ibid., pp. 634-637. 
and had been refused was clear to the mind of everyone. The thought of the revolutionary patriots was not only the creation of an independent judiciary but firm control of such judges as were established.

\section{I}

While the members of the federal convention rejected the English mode of effecting judicial removals by legislative address as being likely to weaken the independence of the courts, at no time did they suggest that the judges should not be punished for misbehavior in the same way as other civil officers of the United States. ${ }^{5}$ It is true, the mode of removal on impeachment and conviction was discussed in the convention in connection with the executive. But its opponents held that this method of removal was proper only in the case of officers appointed during good behavior, and in this way the judges were brought into consideration, a general agreement being reached that in their case impeachments were proper to secure good behavior. ${ }^{6}$

5 Supra, p. 30.

6 Farrand: ii, p. 64. 
The first motion in the convention to provide for removal on impeachment and conviction came from Mr. Williamson, who advocated its application to the executive for "malpractice or neglect of duty." favorably received and was embodied in the report of the committee. When the matter came up for debate on July 20, the idea was accepted by a vote of eight to two, Massachusetts and South Carolina voting in the negative, and was referred to a committee of which Mr. Brearly was chairman. When this committee reported on September 4, the caușes for impeachment were limited to treason and bribery. ${ }^{8}$ To this Colonel Mason objected as being insufficient, and moved to add after the word "bribery" the words "or maladministration." Madison thought that "so vague a term would be equivalent to a tenure during the pleasure of the Senate"; whereupon Mason withdrew his suggestion and substituted "other high crimes and misdemeanors against the State." On the question thus altered, eight states voted in the

7 Farrand: i, p. 88.

8 Ibid., ii, p. 69. 
affirmative, and the clause was accepted. ${ }^{\circ}$ "State" was later amended to read "United States," but this was dropped by the Committee on Style and the clause was finally drawn up in its present form.

The Constitution provides that "the President, Vice-President, and all other civil officers of the United States, shall be removed from office on impeachment for, and conviction of treason, bribery, or other high crimes and misdemeanors." 10 Most of the States have drafted their constitutional provisions on this subject in similar language. As there is no enumeration of offenses comprised under the last two categories, no little difficulty has been experienced in defining offenses in such a way that they fall within the meaning of the constitution provisions. But impeachable offenses were not defined in England, and it was not the intention that the Constitution should attempt an enumeration of crimes or offenses for which an impeachment would lie. Treason and bribery have always been offenses whose nature was clearly understood. Other high crimes and

${ }^{9}$ Farrand: ii, p. 495.

10 Art. ii, Sect. 4. 
misdemeanors which might be made causes for the impeachment of civil officers were those which embraced any misbehavior while in office. Madison, whose objection led to the insertion of the more definite phrase "high crimes and misdemeanors," was the strongest advocate of a broad construction of the impeachment power. He argued that "incapacity, negligence, or perfidy of the Chief Magistrate" should be ground for impeachment." Again, in discussing the President's power of removal, he maintained that the wanton removal from office of meritorious officers would be an act of maladministration, and would render the President liable to impeachment. ${ }^{12}$ Hamilton thought the proceeding could "never be tied down by such strict rules, either in the delineation of the offense by the prosecutors, or in the construction of it by the judges, as in common cases serve to limit the discretion of the courts in favor of personal security." "13

The convention believed the remedy of impeachment and conviction to be adequate for

11 Elliot: v, p. 341.

12 Ibid., iv, p. 375.

13 Federalist, lxv. 


\section{THE UNITED STATES}

the removal of all unfit public officials, so that in its application to the judiciary the impeachment clause must be construed with that clause of the Constitution which guarantees to the judges a tenure during good behavior. It was intended that trial upon impeachment should form a "national inquest into the conduct of public men." The subjects of its jurisdiction were to be those which proceeded from the misconduct of public officers. It was not the province of an impeachment to mete out justice for criminal acts. It was to be its function to protect the people by removing from office and imposing perpetual disqualification from holding office upon such men as showed themselves unworthy of public trust. For that reason it was provided that the chastisement of a misbehaving public official should not cease when he was stripped of his honors, but that he might be pursued and punished for crime in the ordinary course of law, and without being twice placed in jeopardy. For the same reason the trial of impeachments was vested in a legislative body rather than in the courts, as the latter might be called upon to try the offender after he had been removed from office. 
The use of the impeachment power as a check upon the courts in the exercise of the doctrine of judicial review was early advocated by some "high-fliers in Congress and out." After the decision of the circuit court for Pennsylvania in the first Hayburn case, some declared that only a general convention is adequate to pass upon the constitutionality of an enactment. One contemporary editor writes:

Never was the word "impeachment" so hackneyed as it has been since the spirited sentence passed by our judges on an unconstitutional law. The high-fliers, in and out of Congress, and the very humblest of their humble retainers, talk of nothing but impeachment! impeachment! impeachment! as if forsooth Congress were wrapped up in the cloak of infallibility, which has been torn from the shoulders of the Pope; and that it was damnable heresy and sacrilege to doubt the constitutional orthodoxy of any decision of theirs, once written on calf skin! But if a Secretary of War can suspend or reverse the decision of the Circuit Judges, why may not a drill sergeant or a black drummer reverse the decisions of a jury? Why not abolish at once all our courts, except the court martial? and burn all our laws, except the articles of war ... ? 
But when those impeachment mongers are asked how any law is to be declared unconstitutional, they tell us that nothing less than a general convention is adequate to pass sentence on it; as if a general convention could be assembled with as much ease as a party of stock jobbers. ${ }^{14}$

But these radicals gained nothing from their outcries, and the power of the courts to set aside as null and void acts of legislation in contravention of the fundamental law became still more firmly established. ${ }^{15}$

\section{II}

That the impeachment power might be used as a weapon of partisan warfare does not seem to have occurred to the members of the federal convention. But as party spirit developed, the latent possibilities in the impeachment proceeding as a means of destroying political opponents became recognized. Jefferson expressed his fear that the Federalists might resort to such means, declaring:

I see nothing in the mode of proceeding by impeachment but the most formidable weapon for the

14 Bache's General Advertiser, Apr. 20, 1792. A similar paragraph appears in Freneau's National Gazette, Apr. 16, 1792.

15 Corwin: Doctrine of Judicial Review, p. 51. 
purpose of a dominant faction that ever was contrived. It would be the most effectual one for getting rid of any man whom they (the Federalists) consider as dangerous to their views. I know of no solid purpose of punishment which the courts of law are not equal to, and history shows that in England impeachment has been an engine more of passion than of justice. ${ }^{16}$

To prevent such perversion of the impeachment power, the amendment of the clause was suggested in the Senate and Jefferson sought to have juries introduced into trials on impeachments. ${ }^{17}$

It remained for Jefferson and his partisans to make use of this "formidable weapon" for political purposes. The Republicans having become in the elections of 1800 the "dominant faction," the call to battle with their Federalist enemies who still were intrenched in the stronghold of the judiciary was sounded. Early in 1803 Jefferson directed Congress to make the first attack upon John Pickering, judge of the district court for New Hampshire. ${ }^{18}$ The move was well understood at the time and was considered by the Fed16 Madison MSS., Feb. 15, 1798.

17 Jefferson MSS., Jan. 25, 1798. 18 Annals, 7th Cong., 2d Sess., p. 460. 
eralists as the beginning of a systematic attack upon the courts.

The business of "judge breaking" had already been carried far in some of the States before it was attempted in the federal judiciary. In Pennsylvania, where the Republican party had early been successful, the impeachment and removal of obnoxious judges had become a party policy. A beginning was made with Alexander Addison of the State judiciary, who had aroused the democratic element by his political speeches from the bench. Petitions poured into the legislature complaining against the administration of justice in his court, and his impeachment and trial were ordered in 1802. Although Judge Addison defended himself with great ability, his conviction was easily secured and he was removed from office amid the rejoicing of the Republicans. Thomas McKean wrote Jefferson that they "knew how to get rid of obnoxious judges as well as Congress,' and that "the Tories in Pennsylvania were not only humbled but subdued, since Federalism would fall with Addison in the six western counties." "19

19 Jefferson MSS., Feb. 7, 1803. 
Elated with this success, the Republicans determined to bring about the impeachment of all the members of the supreme court of Pennsylvania, except Judge Brackenridge who was of their party. To secure a basis for the prosecution of the judges, the legislature took up a petition which had been presented to them in February, 1803, by one Thomas Passmore, in which he alleged that he had been arbitrarily and unconstitutionally fined and imprisoned for contempt of court. $^{20}$ It was apparent to all, however, that the impeachment was a malicious partisan attack upon the Federalist members of the court, and the entire bar of the State refused to assist in the prosecution. Moreover, the legislature had only a few years earlier refused to move in a similar case, declaring that "an error in judgment is no ground for an impeachment." "21 Because of the flimsy grounds upon which the prosecution was based there was little difficulty in securing the acquittal of the judges, but the legislature 20 Foster: op. cit., p. 663; Trial of the Judges (Lancaster, Pa., 1805).

21 See petition of Eleazer Oswald, Debates 12th Pennsylvania Assembly, 3d Sess., IV. 
thought it wise to enact a statute defining what offenses might be punished as in contempt of court in that State. ${ }^{22}$

The impeachment of judges from partisan motives ceased in Pennsylvania after this defeat, but hostility to Federalist officers did not subside. As a part of the same movement two impeachments were undertaken in Ohio as late as 1808. Two years earlier Calvin Pease, a judge of the circuit court of the State, had held that a portion of the Ohio law respecting the jurisdiction of justices of the peace was repugnant to the constitution of the State and of the United States. This was the first decision in the State which held an act of the State legislature unconstitutional, and was followed by Judges Tod and Huntingdon. Great public excitement was created, and at the next session of the legislature the separate impeachments of Judges Pease and Tod were resolved upon. Judge Huntingdon, in the meantime, had been elected governor, and the charge against him was abandoned. Both judges were acquitted, but the 22 Foster: op. cit., p. 664. 
legislature by a vote of less than two-thirds proceeded to declare vacant their offices. ${ }^{23}$

\section{III}

While these events were in progress in the States, the movement to sweep from the courts of the United States all Federalist partisans was begun. In the first flush of victory in Pennsylvania, Congress proceeded to vote the impeachment of Judge Pickering. President Jefferson is reported to have said to a member of the Senate that "impeachment was but a clumsy engine to get rid of judges.",24 But the Republicans had been almost unanimous during the debates on the repeal of the judiciary act of 1801 in the belief that no other means of removal existed. ${ }^{25}$

Judge Pickering, to the most superficial observer, presented a vulnerable point for the Republican attack. For some time prior to his impeachment it had been known that the administration of justice in his court was subject to irregularities, most of which were traceable to the conduct of the judge himself.

23 Western Law Monthly, ii, p. 1.

24 Ford: Writings of John Quincy Adams, iii, p. 117. 25 Supra, p. 69. 
An unfortunate lapse from dignity during October, 1802, gave the House of Representatives the grounds on which to base articles of impeachment. ${ }^{26}$

A case had arisen in the district court involving the libeling of a ship and cargo for violation of the customs regulations. When the case came before the court, Judge Pickering ordered the ressel and goods to be restored to the owner, but the collector of the port objected on the ground that the judge was incompetent and the proceeding irregular. When the libels were again brought to trial, the judge was so drunk and spoke so wildly and incoherently that the court was thrown into an uproar. A postponement was asked, and the judge replied, "My dear, I will give you to all eternity.", $\mathrm{He}$ then ordered the court to be adjourned until nine o'clock the next morning, observing that he would "then be sober.",

${ }_{28}$ The impeachment was at first presented verbally but the Senate declined to accept this as proper. They declared that the articles must be presented in writing and that no impeachment could be said to exist until such articles had been prepared. Annals, 7th Cong., 2d Sess., p. 267. Also Annals, 8th Cong., 1st Sess., pp. 317-318.

27 Annals, 8th Cong., 1st Sess., p. 339. 
The next day the judge appeared as irrational as ever. Before reaching the courthouse, he had declared his intention of condemning both ship and cargo. But when the case came up and a few witnesses for the claimant had been heard, the judge ordered that both vessel and cargo be restored to the owner and a decree entered to that effect. In vain did the attorney for the government protest that only one side had been heard; the judge refused an appeal, and the court was adjourned amid much confusion. ${ }^{28}$

Articles of impeachment were voted resting upon these facts. When the case came up for trial in the Senate in January, 1804, "the said John Pickering was three times called to answer the articles of impeachment exhibited against him by the House of Representatives, but came not. Upon which a suggestion, by petition, was made to this court that said John Pickering was insane; and Jacob S. Pickering, the petitioner, and son to the said John, requested to be heard by counsel on said suggestion." ${ }_{29}$ This proposal caused much perturbation among the Repub-

28 Annals, 8th Cong., 1st Sess., p. 351 et seq.

29 Ibid., p. 360. 
licans, and several senators vigorously opposed hearing evidence of insanity. John Quincy Adams declares:

The most persevering and determined opposition was made against hearing evidence and counsel to prove the man insane-only from fear that if insanity should be proved, he could not be convicted of high crimes and misdemeanors by acts of decisive madness. Mr. Jackson was for hearing none of these pretenses of insanity; because they might prevent us getting rid of the man. He said the House of Representatives were at that minute debating whether they would not impeach another judge, and by and by Judge Chase's friends would come and pretend that he was mad. Mr. Breckinridge was for proceeding to trial-hearing all the proofs the managers of the House might bring forward of acts of extravagance and folly, and afterwards hear evidence of insanity in mitigation. The dilemma was between the determination to remove the man on impeachment for high crimes and misdemeanors, though he be insane, and the fear that the evidence of this insanity, and the argument of counsel on its legal operation, would affect the popularity of the measure. ${ }^{30}$

The trial of Judge Pickering was marked throughout by a most offensive show of par30 J. Q. Adams: Memoirs, i, pp. 299-300. 
tisanship. The evidence against him was $e x$ parte and the proceedings were probably not impartial. But there can hardly be found any ground to challenge the use of the impeachment power in this case as improper or to allege that it had been subject to abuse. Several senators refused to vote on the articles, alleging that the offenses charged against the judge did not amount to high crimes and misdemeanors. ${ }^{31}$ But these same gentlemen had accepted the theory of impeachments laid down during the debates on the repeal of the judiciary act of 1801, upon which the charges in this case rested, i.e., that of considering misbehavior and high crimes and misdemeanors as synonymous terms. ${ }^{32}$ Still others objected that Judge Pickering was undoubtedly insane and was, therefore, not amenable to any judicial tribunal for his acts. But Hamilton in expounding the Constitution had expressly admitted insanity to be a cause of removal, while disapproving any other measure of inability. ${ }^{33}$ 31 J. Q. Adams: pp. 304-309.

32 See speech of Senator White, Annals, 7th Cong., 1st Sess., pp. 117-122.

33 Federalist, lxxix. 
And it would be difficult to find greater evidence of that incapacity which Madison and others thought a cause for impeachment. John Quincy Adams, although he voted "not guilty" on all of the articles of impeachment, admitted that "there were circumstances in the case of Mr. Pickering which might at once contribute to veil the designs of his prosecutors, and to apologize for the complaisance of his judges." ${ }^{34}$

The Pickering impeachment would have been of little importance as an isolated case. For the office of judge, Mr. Pickering wàs utterly unqualified, and as the sentence extended only to removal, the effect worked no injustice. His family and friends had suffered him to go at large and to take his place upon the bench, although he had been relieved of his judicial duties at least twice in 1801 during temporary periods of insanity. Since he could not be induced to resign, it was eminently proper that he be removed from office by impeachment as the only means known to the Constitution.

But the impeachment of Judge Pickering was only the initial step in a movement 34 Ford: Writings of John Quincy Adams, iii, p. 108. 
wherein the Republicans aimed to replace the Federalists upon the judiciary with their own partisans and to bring the judges within the control of the legislature. That their efforts were confined for the most part to the federal judges was due to the fact that in the States the courts still remained under legislative control as had been the practice since 1776 . On the very day upon which Mr. Pickering was convicted, the impeachment of Justice Chase of the United States Supreme Court was voted. The first impeachment "did not sufficiently develop the intentions of those by whom it was managed; it did not disclose the full extent of their views." ${ }^{35}$ But with the assault upon Justice Chase it became apparent that the majority party in Congress had determined to carry out Giles' plan to "sweep the supreme judicial bench clean" through the process of impeachment.

A new and broader theory of impeachments under the Constitution was asserted by Giles, who declared:

An impeachment is nothing more than an inquiry by the two Houses of Congress whether the office of a public man might not be better filled by 35 Ford: iii, p. 109. 
another. He labored with excessive earnestness to show . . . certain principles upon which not only Mr. Chase but all of the judges of the Supreme Court, excepting the last one appointed, must be impeached and removed. He treated with the utmost contempt the idea of an independent judiciary ... said there was not a word in the Constitution about such an independence, and that their pretensions to it were nothing more nor less than an attempt to establish an aristocratic despotism in themselves. The power of impeachment was given without limitation to the House of Representatives, and the power of trying impeachments was given equally without limitation to the Senate. And if the judges of the Supreme Court should dare, as they had done, to declare an act of Congress unconstitutional or to send a mandamus to the President, as they had done, it was the undoubted right of the House of Representatives to impeach them, and of the Senate to remove them for giving such opinions, however honest or sincere they may have been in entertaining them. A trial and removal of a judge upon impeachment need not imply any criminality or corruption in him, but was nothing more than a declaration of Congress to this effect: You hold dangerous opinions, and if you are suffered to carry them into effect you will work the destruction of the nation. We 
want your offices for the purpose of giving them to men who will fill them better. ${ }^{36}$

Even among the Republicans this broad view of the impeachment power did not find ready acceptance and a serious division in the ranks of that faction soon appeared..$^{37}$ Not even the managers of the prosecution were agreed upon the line of argument. While John Randolph supported the view of Giles that the impeachment power is without limit, he was contradicted by other managers who contended that an offense amounting to a crime must be proved to obtain a conviction. The excessive vanity and insolence of Randolph and the repeated contradictions of the other managers threw the argument for the prosecution into such confusion that Timothy Pickering became "persuaded they sincerely wished they had not meddled with Judge Chase.",38 The managers soon proved to be no match for Mr. Chase and his attorneys, who put such fair and legal construction upon his judicial acts that his acquittal was secured

36 J. Q. Adams: Memoirs, i, pp. 321 et seq.

${ }^{37}$ Life and Correspondence of Rufus King, iv, p. 440.

38 Ibid., iv, pp. 441-442. 
by a good margin, six of the Republican senators voting with the Federalists in his favor. ${ }^{39}$

\section{IV}

With the acquittal of Justice Chase the partisans of Jefferson were forced to abandon their attempt to bring about the removal of Federalist judges through the impeachment process. Nevertheless, Randolph was determined to find further means of bringing the judges under legislative control. To this end he hurried from the high court of impeachment upon its adjournment to introduce in the House of Representatives a bill proposing a constitutional amendment whereby the judges of the courts of the United States might be removed on joint address of the two Houses of Congress. ${ }^{40}$ He declared a principle had been established by the Senate "that an officer of the United States may act in as corrupt a manner as he pleases, without there being any constitutional provision to call him to account." His motion was seconded by Mr. Smilie, who thought "that part 39 See Report of the Trial of Samuel Chase, 2 vols. (Baltimore, 1805).

40 Annals, 8th Cong., 1st Sess., p. 1213. 
of the Constitution which relates to the power of impeachment had become a nullity,' and that it had become impossible to convict any man upon an impeachment. ${ }^{41}$ But it was then too late in the session for Congress to take up the consideration of the measure.

The procedure of removal on joint address of the two houses of the legislature had been incorporated in many of the early State constitutions. ${ }^{42}$ It was borrowed from the English Act of Settlement which guaranteed the judges a tenure during good behavior, but made them removable by the crown upon address of the two Houses of Parliament. Under the English system the address was originally a petition to the crown, but under the modern theory of Parliamentary sovereignty the address became essentially an exercise of the legislative power of Parliament. Of course, the concurrence of the crown is essential to a removal, but the refusal of such assent would be as startling as an exercise of

41 Annals, 9th Cong., 1st Sess., pp. 502-503.

42 Of the revolutionary State constitutions five contained provisions for the removal of judges on address or upon joint resolution of the houses of the legislature. See Horace Davis: American Constitutions, J. H. U. Studies, Series 3, p. 508. 
the veto. Since no legislative body in the United States or in any of the States is endowed with the complete sovereignty possessed by the British Parliament, the procedure of removal on address has of necessity suffered such modifications as practice demanded. Massachusetts sought to embrace in the exercise of the removal the four organs of government-the two houses of the legislature, the governor, and the council. ${ }^{43}$ Other States have left the judges removable on joint resolution of both houses of the legislature but have provided for a hearing and a statement of causes making the procedure similar to that of an impeachment. ${ }^{44}$

The intention of the framers of the early State constitutions with respect to the provisions for removal on address is somewhat difficult to determine. In England the procedure was adopted as an additional means of securing good behavior on the part of the judges. It did not supersede impeachment, but was available for the removal of judges for any offense whatsoever. At the same time it placed in the hands of Parliament a 43 Thorpe: Charters and Constitutions, p. 1905. 44 Stimson: Federal and State Constitutions, pp. 232-233. 
means of superintending the administration of justice. ${ }^{45}$ The only case in which an address for the removal of an English judge received the sanction of both Houses of Parliament and the compliance of the crown charged an impeachable offense. ${ }^{46}$ On a recent occasion the House of Commons showed its willingness to consider the expedient of address for the removal of a judge who had criticised members of Parliament in a public address. ${ }^{47}$ The removal of an English judge, therefore, is but an act of sovereignty, subject to no conditions save such as are voluntarily imposed.

It seems clear, however, that the framers of the Massachusetts constitution of 1780 in adopting the procedure of removal on address intended that this expedient should be used

45 For a study of the English mode of removal on address see Todd: Parliamentary Government in England, i, pp. 352 et seq., and ii, pp. 727 et seq.; Broom: Constitutional Law, pp. 792 et seq.; Hansard: Parliamentary Debates, lxvii, pp. 1006, 1027; clxiii, p. 900; clxxxii, p. 1629; clxxxiii, p. 835.

46 Sir Jonah Barrington, Judge of the High Court of Admiralty, who was removed in 1829 . See Todd: op. cit., ii, p. 736 .

47 Parliamentary Debates, 5th Series, xxi, p. 291; xxii, p. 366. 
only in cases not warranting impeachment. John Quincy Adams in 1803 dissented from a vote of the legislature for the removal of two judges on the ground that "no judicial officer should be removed from office, by the mode of an address of the two houses, on the ground of offences, for the trial of which the constitution has expressly provided the mode of impeachment." ${ }_{48}$ Further support for this view of the power of removal on address may be found in the debates of the constitutional convention held in 1820. Justice Story declared, "The governor and council might remove them (the judges of the supreme court) on address of a majority of the legislature, not for crimes and misdemeanors, for that was provided in another manner.', Chief Justice Shaw, of the supreme court of the State, thought the mode of removal on address was to be used in cases of incapacity from natural infirmities or some disability, and impeachment should be the remedy in

48 Paul D. Sargent and William Vinal, judges of the court of common pleas in Hancock County, were removed after having been convicted of willful extortion in office. Ford: Writings of John Quincy Adams, iii, p. 12. 
cases involving crime or misbehavior. ${ }^{49}$ The early practice proved to be in harmony with this theory when Theophilus Bradbury, having been stricken with paralysis in 1803, was removed from the supreme court upon address. ${ }^{50}$

But in Kentucky no limits were placed upon the power of the legislature to vote an address for the removal of a judge. The subject was discussed in the constitutional convention of 1799, and a proposition to render impossible the removal of judges for a judicial opinion, or without a finding facts by a competent jury, was defeated. ${ }^{51}$ At no time did the Kentucky general assembly allow the good behavior tenure guaranteed the judges to interfere seriously with their control of the judiciary. On several occasions courts were abolished for the sole purpose of getting rid of objectionable judges. As early as 1795 , an effort was made to address out of office Judges Muter and Sebas-

4916 American Law Review, p. 552; Debates of the Convention (1820), p. 216.

50 Foster on the Constitution, p. 642.

51 Breckinridge: Administration of Justice in Kentucky (Dissertation, University of Chicago, 1897), p. 36. 
tian because of a decision in a case touching conflicting claims to the same land under grants by the commission constituted under Virginia laws. A second attempt to remove Judge Muter was begun in 1806 on the ground that he had become too aged and infirm to perform judicial duties. The judge was induced to resign before the address was voted, and was granted a pension which the legislature repealed in 1809 over the veto of the governor. ${ }^{52}$ In the same year Judge Sebastian was summoned before the legislature on a charge of having received a bribe from the Spanish government, but his immediate resignation prevented further action. ${ }^{53}$ Encroachments upon the judicial department continued at intervals until 1824, when an attempt was made to address the entire supreme court of State out of office on the ground that such power was available "for any mere error of judicial opinion, which does not amount to misdemeanor, if it inflicts upon the community such injury as in their belief amounts to a reasonable cause of re-

52 Breckinridge: op. cit., pp. 74-77.

53 Monroe MSS., Jan. 3, 1807. 
moval, provided only that they observe the constitutional form."

Whatever may have been the motive for placing the mode of removal on address in the various State constitutions, the practice has been to use the expedient as an alternative for impeachment. In New Hampshire a consistent effort was made to restrict the use of removal on address to cases of mental and physical incapacity, and the early removals were for such causes. ${ }^{55}$ But in 1871 a number of removals were made for political reasons and an attempt by constitutional amendment to prevent a recurrence of such use of the power of removal on address was defeated at the polls. ${ }^{56}$

After 1803 the Massachusetts legislature returned to the principles laid down by the framers of the constitution, and for a time impeachment was the only remedy used in cases of crimes and misdemeanors. ${ }^{57}$ But more recently the legislature has declared 54 Breckinridge: op. eit., pp. 78-82.

55 Granite Monthly, iv, p. 133.

${ }^{56}$ American Annual Cyclopedia (1871), p. 543; (1877), p. 547.

57 Impeachment of Judge Prescott (1821), Foster: op. cit., p. 641. 
that "everything which indicates the fitness or unfitness of a judicial officer may be considered upon the question of his removal on address." ${ }^{58}$ Since the Civil War at least two removals have been effected in Massachusetts for offenses which could have been prosecuted under the impeachment clause.

In some of the States the mode of removal on address has been used to rid the bench of judges whose offenses were so serious as to have demanded their removal upon impeachment in order that disqualification from holding further office might be imposed. During the period immediately following the Civil War the circuit judiciary of West Virginia was burdened with Nathaniel Harrison, a notoriously corrupt and intemperate man. Several attempts were made to address Judge Harrison from the bench because of the maladministration of his office and the lewd and corrupt manner of his life. These failed because a majority of the legislature approved his persecution of ex-Confederates and were willing to overlook his defects of character. But his conduct in 1870 aroused 58 Foster: op. cit., p. 643. See also Report of Committee on Removal of J. M. Day (Boston, 1881). 
such widespread indignation that resolutions for his removal passed both houses of the legislature. In the meantime the judge had fled to Pittsburgh, where he took refuge in a brothel and forwarded his resignation to the governor. ${ }^{59}$ All of the removals on address in New York have been for such malversation in office as would properly have been subjects of impeachment in order that the people of the State might have no fear of the offenders being again placed in office. ${ }^{60}$

It is perhaps surprising to find that the form of address has seldom been used to remove judges for political reasons. While legislatures have been very active in limiting the functions of the judiciary and have been extremely parsimonious in providing salaries for the judges, there have been no such partisan attacks through the mode of address as were undertaken during the Jeffersonian period through the impeachment process. Maine claims the distinction of having made the first judicial removal on address on the grounds of party policy. In 1856, Woodbury 59 Laws of West Virginia (1870-1871), p. 136; Why the Solid South? pp. 282-284.

${ }^{60}$ Foster: op. cit., pp. 645-657. 
Davis, a justice of the supreme court of the State, was removed as a result of a partisan attack by the governor and the legislature. A dispute had arisen over an opinion of the judge upon a constitutional question which he had declared wisely and temperately, but against the interests of the party in power. Instead of taking an appeal to the full bench of the supreme court, an address was carried in both houses along party lines and the assent of the governor secured for the removal of Judge Davis. ${ }^{61}$ A few years later, Massachusetts was the scene of a partisan removal when the abolitionists attacked Judge Loring. The judge had incurred the hostility of the extreme abolitionists by his execution of the fugitive slave law while acting as United States Commissioner. The removal was urged by Wendell Phillips, who gave an impassioned harangue before the assembly, in which he sought to show the unlimited power of the legislature to ask the removal of a judge who had acted contrary to public sentiment. But the address did not pass the legislature until after a long debate, 61 Adams: Life of Richard Henry Dana, i, p. 351; Law Reporter, xix, pp. 61 et seq. ; p. 652. 
and two years more elapsed before a complaisant governor could be found to assent to the measure. ${ }^{62}$

As a matter of fact, removal on legislative address has become in nearly all States obsolete. Short terms and popular elections have made the judges more responsible to public opinion, but have at the same time rendered them more independent of legislative control. Then, too, the exercise of the power of removal on address has been hedged about by many constitutional restrictions. In most States a majority of two-thirds of both houses of the legislature is required to pass an address, while in many States the judge is entitled to a hearing and a statement of the causes for removal. The procedure is thus made as cumbrous and unwieldly as an impeachment and legislatures have hesitated to undertake its exercise. In recent years the tendency has been to free the judiciary from legislative control, and to this end Alabama, Florida and Mississippi have removed the provisions relating to legislative address

62 Phillips: Speeches and Lectures (5th ed.), pp. 154-212; Adams: op. cit., i, pp. 341-347; Merriam: Life and Times of Samuel Bowles, i, pp. 131-134. 


\section{THE UNITED STATES}

from their constitutions. ${ }^{63}$ At the present time discussions of means of securing responsibility on the part of judges and the determination of good behavior have centered on new remedies such as the popular recall.

\section{V}

Efforts to incorporate in the federal Constitution provisions for the removal of judges upon legislative address have been made on nearly every occasion when the courts have been under criticism. Such criticism has developed in four well-marked and definite periods of our history, in each of which Congress has been besought to place restraints upon the judiciary either by limiting the functions of the courts or by introducing new means of controlling the judges. Nearly all of these proposals are to be traced either to partisan desire to control the judiciary or to efforts to restrain the judiciary from passing upon the constitutionality of acts of Congress.

The attempts of the Republicans during the administration of Jefferson to oust the Federalists from the judiciary resulted in the introduction of numerous propositions for 63 Thorpe: op. cit., pp. 207, 802, 1110, 2110. 
the removal of judges by legislative address. While Congress turned to other matters of public policy, pressure from the State legislatures kept the issue alive. The legislature of Vermont in 1807 sent resolutions to the other State legislatures calling attention to the want of a provision for the removal of judges of the federal courts except for causes warranting impeachment. ${ }^{64}$ Pennsylvania favored the adoption of an amendment giving Congress power to remove judges on legislative address, but Delaware and Rhode Island objected to such provision and instructed their senators and representatives to oppose its adoption. ${ }^{65}$

A general feeling predominated that impeachment could not be used in practice and that some other means of keeping the judges in order ought to be introduced. Jefferson thought that impeachment was "not even a scare crow" and that the courts had become "independent of the will of the nation itself." "'e The independence of the judges was 64 Annals, 10th Cong., 1st Sess., p. 99.

65 Journal Pennsylvania Senate (1807-1808), pp. 163170 ; Annals, 11th Cong., 2d Sess., p. 631.

ee Works (ed. Ford), vii, pp. 134, 192. 
held to be "one of the greatest absurdities that can possibly be imagined, and in many instances operates exactly the reverse of what was expected by the people: In many instances it is a continuance during bad behavior." ${ }^{67}$

The partisan attack upon the judiciary ceased only to break forth again after a few years in a States' rights movement to restrict the appellate jurisdiction of the Supreme Court of the United States. The great constitutional decisions under Chief Justice Marshall aroused the defenders of State sovereignty, and those who had begun the assault upon the courts for the purpose of making partisan removals now turned their attention to measures limiting the jurisdiction and functions of the judiciary. Following the decision in Cohens v. Virginia (6 Wheaton 264), resolutions of protest were passed by the Virginia legislature and proposals to urge a series of amendments to the Constitution placing limitations upon the power and jurisdiction of the federal courts

67 Experience the Test of Government (Philadelphia, 1805). 
were defeated by a narrow margin. ${ }^{68}$ When Congress assembled in 1821 it was proposed to have an amendment to the Constitution giving the Senate appellate jurisdiction "in all controversies where the judicial power of the United States shall be so construed as to extend to any case ... arising under the Constitution, and to which a State shall be a party." ${ }_{69}$ While this proposition did not meet with much favor, it gave opportunity for the introduction of another bill to provide an amendment giving Congress power to remove judges upon legislative address bottomed on the idea that the judges were too independent for the public good..$^{70}$

In reality the opponents of the judiciary had changed the basis of their attack from that of a partisan movement against the judges to an effort to subordinate the federal courts to the theory of State sovereignty. In the new movement only the radical States' rights faction was active. Their struggle culminated in the attempt in 1831 to repeal the

68 Ames: Federal Relations, p. 103.

69 Annals, 17th Cong., 1st Sess., p. 68.

70 See speech of Mr. Holmes, Annals, 17th Cong., 1st Sess., p. 114. 
$25 \mathrm{th}$ section of the judiciary act of 1789 . In this they were so decisively defeated in the House of Representatives that they gave up all further efforts to place restriction on the courts. ${ }^{71}$

A third assault upon the independence of the federal judiciary was undertaken just after the close of the Civil War, when the United States Supreme Court began to emerge from the somewhat humble position into which it had been cast by the circumstances surrounding the decision in the Dred Scott case. During the winter of 1866 and 1867 the court handed down several decisions which boded ill for the radical projects of reconstruction. Proposals were made to create a special tribunal to decide constitutional questions, to require two-thirds of the supreme court to declare an act of Congress unconstitutional, and to make possible the removal of judges upon legislative address. ${ }^{72}$ None of these measures became law since the supreme court soon showed a willingness to 71 E. S. Corwin: Michigan Law Review, ix, p. 283; Niles Weekly Register, xxix, p. 401.

72 Globe, 39th Cong., 2d Sess., pp. 251, 492-498, 1313. 
acquiesce in the plans for reconstruction, and opposition to the courts was stilled.

The recent criticism of the judiciary, both State and national, has developed because of the numerous legislative enactments which have been set aside by the courts, especially such acts as were believed to be in line with social and economic progress. From this agitation has sprung the new procedure of the popular recall of judges and the demand for the popular review of decisions in which the courts have set aside legislative enactments. It is important to note that it is not legislative control of the courts which is now advocated but the responsibility of the judiciary to the people. ${ }^{73}$

Nevertheless, several propositions have been made looking towards the establishment of removal on legislative address. One of these urged in the House of Representatives by Mr. Hull of Tennessee seeks to establish a simplified substitute for impeachment. Mr. Hull has taken the further view that the regulation of inferior courts is within the power of Congress and it is not unbecoming for the two houses to exercise a power of 73 Cong. Record, 63d Cong., 1st Sess., p. 1052. 
removal with respect to inferior judges. But the supreme court he terms a "constitutional court" and omits its justices from the operation of his provision on the ground that their inclusion would be inconsistent with a proper co-ordination of the departments of government. ${ }^{74}$ Much more radical than this was the proposition brought forward by Senator Owen in July, 1911. This proposal was in the form of a bill to provide for the "legislative recall" of any judge of a federal court by the simple expedient of a resolution passed by Congress calling upon the President to nominate a successor to such judge. The constitutionality of this measure was urged on the ground that while the Constitution provides for the removal of judges upon impeachment, Congress is given a variety of powers to regulate the judicial establishment and from these is to be implied not only the power to recall but also to elect federal judges. ${ }^{75}$

Although most of these efforts to impose restraints upon the courts and to limit the independence of the judges have been actu-

74 63d Cong., 1st Sess., H. J. Res. 114.

75 Cong. Record, 62d Cong., 1st Sess., p. 3359. 
ated by motives which threatened danger to the judicial department, there has been a well-defined feeling that under the Constitution misbehavior on the part of judges could not be punished. There can be no doubt that while on the one hand the acquittal of Justice Chase was salutary in checking partisan attacks on the judiciary, on the other hand the result was practically to narrow the impeachment power to such limits as were never intended by the framers of the Constitution. There was created in the minds of men the firm belief that where any defense was made, conviction upon impeachment was impossible before men of ordinary prejudices and passions, and that the judges were thus exempt from all control.

This belief was voiced in Congress in 1830, when James Buchanan declared that "if the power to impeachment presents no prospect to the people of removing an arbitrary and tyrannical judge, the people will soon begin to inquire whether the judicial office ought not to be limited to a term of years." same view was reiterated in greater detail by Judge Spencer, who said:

76 Trial of Judge Peck (Washington, 1831), p. 289. 
If the constitutional power of the House of Representatives to impeach officers of this government, and the power of the Senate to try them, should become inefficient and a solemn mockery, as it has been represented it would be; and if the people came to believe that guilty men can pass this ordeal unhurt and untouched, the inevitable consequence will be that the tenure of judicial offices will be changed, and the independence of the judiciary will be destroyed. ${ }^{77}$

Subsequent efforts to make use of the impeachment power have tended to strengthen this feeling. In the United States only six cases have come to trial before the Senate since the acquittal of Justice Chase. ${ }^{78}$ If we except the case of Judge Humphreys, who was removed on an impeachment when he

i7 Trial of Judge Peck, p. 473.

78 The following impeachments have been undertaken before the Senate in the course of our history: William Blount, Senator from Tennessee, acquitted 1798; John Pickering, Judge of District Court, convicted 1803; Samuel Chase, Justice of Supreme Court, acquitted 1805; James H. Peck, Judge of District Court, acquitted 1831; West H. Humphreys, Judge of District Court, convicted 1862; Andrew Johnson, President of the United States, acquitted 1868; William Belknap, Secretary of War, acquitted 1876; Charles Swayne, Judge of District Court, acquitted 1905; Robert W. Archbald, Judge of Commerce Court, convieted 1913. 
adhered to the Confederacy and refused to resign his federal office, and who was impeached because there was no other way of effecting his removal, no convictions were secured until 1913. In each case that has arisen the defense has sought to restrict the scope of the impeachment power to very narrow limits and has succeeded in leading a sufficient number of senators to vote for acquittal in the belief that the offenses charged did not amount to high crimes and misdemeanors.

\section{VI}

But a great change has been wrought in the popular attitude toward the impeachment power by the recent conviction of Judge Archbald, of the United States Commerce Court, who was removed in 1913. Indeed, it has seemed that the ancient remedy can be made as effective as intended by the framers of the Constitution. The results in this case have demonstrated that party lines can be swept aside and the technicalities of pleading rejected where it is sought to reach a man wholly unfit for office. Moreover, the scope of the impeachment power was revealed as 
transcending the narrow limits imposed by the results of the Chase trial. It appeared fully competent to protect the people against unfitness in public officers and became again a vigorous weapon as intended by the framers of the Constitution. ${ }^{79}$

Prior to his impeachment Judge Archbald had enjoyed a long judicial career. He was appointed in 1901 a judge of the federal district court for the middle district of Pennsylvania, where he sat until January, 1911. He was then promoted to the circuit court and was assigned to service on the newly created commerce court. In the course of his trial it became evident that the judicial misconduct of which Mr. Archbald had been guilty had extended over the entire period he had been upon the bench.

Charges of misconduct on the part of Judge Archbald were first brought to the attention of President Taft in February, 1911. After a careful investigation by the Department of Justice, the matter was thought to be of sufficient importance to claim the attention of the House of Representatives and, accord-

79 Trial of Robert W. Archbald (3 vols.), 63d Cong., 3d Sess., Senate Document 1140. 
ingly, in May all the papers in the case were transmitted to them. The testimony showed that at different times Judge Archbald while on the district bench had sought credit from persons who had litigation in his court. After his appointment to the commerce court, the judge had used his influence to secure favorable business negotiations with common carriers engaged in interstate commerce and having at the time suits pending in his court. These were for the most part contracts involving options on culm dumps and other coal properties obtained from officers and agents of coal companies which were owned and controlled by the common carriers. Judge Archbald repeatedly sought to influence the officials of the railroads to enter into contracts with his business associates for the financial benefit of himself. While the friends of the judge would locate properties, Mr. Archbald would take up the matter of the purchase or sale of the properties with the railroad companies. He never invested money himself in any of the deals but used his influence to secure favorable terms in consideration of which he was to receive a share in the profits. 
The charges set forth in thirteen articles of impeachment presented no indictable offenses. In all cases they alleged instances of misconduct in office which, if true, constituted breaches of the good behavior tenure granted judicial officers. Judge Archbald admitted generally the facts stated in each article but declared that in no case did the charge amount to an impeachable offense. Moreover, he sought to limit the scope of the impeachment power to such offenses only as were indictable, and insisted that only those offenses which were alleged to have been committed in his judicial capacity should be considered. This interpretation would have confined the operation of the impeachment power to such narrow limits as to include only acts of misconduct which amounted to crime within the meaning of the terms high crimes and misdemeanors.

This narrow construction of the impeachment power was at once denied by Senator Works. Such construction, he said, would continue in office any officer whose bad behavior did not reach the magnitude of crime. The only question to be answered, he considered, was whether Judge Archbald was 
guilty of such misbehavior as would give cause for the forfeiture of an office he was entitled to hold during good behavior. That acts of misbehavior were to be construed as high crimes and misdemeanors, although no crime could be proved, was the view shared by Senators Root and Lodge. But Mr. Root felt that some of the charges, although they involved improper conduct, fell short of high crimes and misdemeanors. After the conviction of Judge Archbald he issued a statement in which he declared:

I have voted the respondent "guilty" because I find that he used the power and influence of his office as judge to secure favors of money value for himself and his friends from railroad companies, some of which were litigants in his court and all of which were under the regulation of the Interstate Commerce Commission subject to the review of the Commerce Court. I consider this course of conduct, and each instance of it, to be a high crime and misdemeanor. I have voted "not guilty" upon other articles because, while most of them involve improper conduct, I do not consider that the acts proved are high crimes and misdemeanors. ${ }^{80}$

80 Cong. Record, 62d Cong., 2d Sess., p. 1448. 
The first article upon which Senator Root voted guilty, and upon which Judge Archbald was convicted by so large a vote as to be practically unanimous, charged him with having entered into an agreement with one Edward J. Williams whereby they became partners for the purchase of a property known as the Katydid culm dump near Moosic, Pennsylvania. This property was owned by the Hillside Coal and Iron Company, a corporation all of whose stock was owned by the Erie Railroad Company, and one John M. Robertson. Williams, having been assured that the share of Robertson could be purchased, sought the aid of Judge Archbald in securing the interest held by the Hillside Coal and Iron Company.

Despite the fact that the Erie Railroad Company was a party litigant at this time to several suits before the United States Commerce Court, Judge Archbald entered into negotiations for the purchase of the property. By correspondence and personal conference, not only with officers of the Hillside Coal and Iron Company but also with the officers of the Erie Railroad Company, he secured the transfer of the Katydid culm 
dump to the partnership he had formed with Williams.

Similar misconduct was charged in the third article upon which conviction was also secured. In this instance Judge Archbald was accused of having used his influence to secure from the Lehigh Valley Coal Company a lease on a culm dump near Shenandoah, Pennsylvania. The coal company was owned by the Lehigh Valley Railroad Company, which was at that time a party to at least two suits before the commerce court.

Upon the fifth article charging slightly different misbehavior Judge Archbald was convicted by as decisive a vote as before. In this case it was shown that the judge had undertaken to intercede with the officials of the Philadelphia and Reading Railroad Company to secure favorable consideration toward a friend. Frederick Warnke of Scranton, Pennsylvania, had sought repeatedly to secure a lease on a near-by culm dump owned by the Philadelphia and Reading Coal and Iron Company. His efforts were in vain although he had negotiated with the officers of the owning corporation and with the president of the Philadelphia and Reading Rail- 
road Company. He then turned to Judge Archbald who sought to influence the officers of both corporations to accede to the proposition made by Warnke. Although he failed in his mediation, Judge Archbald was rewarded by the payment of a promissory note drawn by Warnke and his associates.

Misconduct in his judicial capacity was charged against Mr. Archbald in the fourth article. Here it was proved that while the suit of the Louisville and Nashville Railroad Company v. Interstate Commerce Commission was pending in the commerce court a letter was written by Judge Archbald to the attorney for the railroad company asking information as to the testimony of one of his witnesses. Without the knowledge of the other members of the commerce court, Judge Archbald entered into correspondence with the attorney for the railroad company disclosing certain developments unfavorable to the case of the company and soliciting further arguments in support of their contentions. This action was taken secretly and without the knowledge of the Interstate Commerce Commission.

On this article Judge Archbald was con- 
victed by a trifie more than two-thirds of the Senate. Mr. Root voted not guilty, expressing the view that while improper conduct was involved there was no justification for declaring the acts to be high crimes and misdemeanors. Mr. Lodge, who concurred with $\mathrm{Mr}$. Root in his vote upon all the other articles, voted the respondent guilty upon this charge.

The specific charges of misconduct raised in the first twelve articles were reinforced in the last article by a general charge of misbehavior during the judicial career of Mr. Archbald. Some objection was made by senators to this article on the ground that it was not limited to definite offenses. Nevertheless, it presented a comprehensive statement of the sort of misbehavior for which the judge was being impeached, and his conviction on this article was a distinct triumph for the broad view of the impeachment power.

Expressions of satisfaction with the action of the Senate in the Archbald case were heard on all sides. The journals hailed the result as an effective answer to those who argued that impeachment was wholly inadequate for practical purposes, and many saw 
in it a check upon the agitation for the popular recall. The Nation in an editorial declared :

The removal of the impeached judge, with his disqualification ever again to hold an office of honor or trust under the United States, serves at once as a salutary warning, a notification that the ancient remedies of the Constitution have not lost their virtue, and a revelation that the people are aroused and vigilant as regards anything that may stain the purity of the judiciary.

No one accused Judge Archbald of any crime for which he could be punished in a court of justice. There was no charge of bribery or indirect sale of decisions. The only legal question was whether the conduct of which he was shown to be guilty came under the head of misdemeanors or of a breach of that good behavior upon which judicial tenure depends, in such a way that the Senate could properly remove him from the bench. ${ }^{81}$

Unexpected reinforcement to the impeachment power has been given through the result of the trial of Governor Sulzer of New York, who was removed in the autumn of 1913. Although the impeachment was a purely political matter, the charges rested upon broad grounds of unfitness and involved 81 Nation, Jan. 16, 1913. 
offenses committed by Mr. Sulzer prior to his election. The significance of this removal lies in the fact that very broad scope can be given to the impeachment power with reasonable certainty of finding popular approval.

The most superficial student of the history of our courts must agree with Bryce that although "the judges have shown themselves independent of Congress and of party, yet the security of their position has rarely tempted them to breaches of judicial duty." Impeachment has been resorted to seldom, but the tone of the federal judiciary has been far better than that of most of the State courts. The acquittal of Justice Chase placed a wise check upon partisan assaults against the courts, although it tended to discourage all use of the impeachment power. The courts have thus been able to exercise fearlessly and unhampered the great powers entrusted to them by the Constitution. At the same time it has been possible to punish in an effective manner lapses from judicial dignity or the perversion of office to improper ends. 


\section{CHAPTER IV \\ SELECTION AND TENURE OF JUDGES}

The tenure of office and mode of selection of the federal judges as provided by the convention of 1787 was designed to establish the judiciary as a co-ordinate and independent department of government. The judges were chosen neither by the will of one individual nor by the vote of one branch of the government, but by the concurrent wishes of the President and Senate. They held their offices not at the pleasure of any group, but by the secure tenure of their own good behavior. The federal courts were thus in a position to decide disputes in an enlightened and impartial manner, and to pronounce their opinions without fear, favor, or partiality.

In marked contrast to the independence enjoyed by the federal courts, the judiciary in the several States continued under the legislative domination beneath which they 
fell in the revolutionary constitutions. In a majority of the States judges were chosen by the popular assemblies, and not even the action of the convention of 1787 in joining the executive and one branch of the legislature in the selection served to bring about a reform in this respect. Only the tenure of office during good behavior assured the judges in most of the States contributed to erect the judiciary as a respectable branch of the government.

The security of the judicial office so ardently advocated by the colonists tended to discourage any attempt to place limitations upon the tenure of office of the judges. In nearly all of the States tenure during good behavior was granted the judges, even before the convention of 1787 had stamped this standard with its approval. In Pennsylvania where a term of years was provided for the judges of the first courts established, under the influence of the council of censors a change was made in 1790 to the more secure tenure during good behavior. ${ }^{1}$ Likewise the new States of Vermont, Kentucky, and Tennessee, which were admitted soon after the 1 Thorpe: Charters and Constitutions, p. 3079. 
ratification of the federal Constitution, provided for their judges a similar tenure. ${ }^{2}$ In Georgia, New Jersey, Rhode Island, and Connecticut alone were short term commissions granted the judges. While legislative appointment was held in high favor as affording the best method of selecting judicial officers, the States were uniformly satisfied that a tenure during good behavior was sufficient to insure the independence of the courts.

The most complete subordination of the courts to legislative control was attempted in the Ohio constitution of 1802. The growing sentiment of democracy which stamped the partisans of Thomas Jefferson permeated this charter. Legislative control not merely of the judiciary but of all the organs of government was its chief characteristic. In the East such notions came into violent conflict with the older views, but west of the Alleghenies they found a virgin soil. Under this influence the people of Ohio gave their governor no power of veto, entrusted him with no appointments to office, and limited the commissions of all officers to a fixed term of years. The judges were to be selected by the 2 Thorpe: pp. 1270, 3419, 3765. 
legislature, and were to hold office for a term of seven years "if so long they behave well.", They were further required to hold a supreme court in each county of the State which kept them on horseback half the year and compelled them to give decisions in frontier towns where no law books could be had. Naturally this led to confusion in the law. ${ }^{4}$

It soon became apparent that the radical innovations introduced by the constitution of 1802 were unwise. Several attempts were made by the legislature to modify the judiciary system, but in 1809 Governor Huntington found it necessary to call attention to defects which still.existed and to urge their remedy. ${ }^{5}$ The first supreme court of the State is said to have been composed of exceptionally able men, yet "it was the opinion of the bar generally that the judges ought to have been appointed during good behavior. Serious fears were entertained that the short terms of their offices would lead to a want of stability and uniformity of decisions; and

3 Thorpe: p. 2908.

4 Burnet: Notes on the Northwest Territory (Cincinnati, 1847), p. 356; Debates Ohio Convention, 1850, p. 597.

5 House Journal (1808-1809), pp. 196-199. 
might bring them under the influence of leading political men. Fears were also entertained that in times of high party excitement judges would be selected rather for their opinions than for their legal acquirements." Except for the Indiana constitution of 1816, none of the other States seems to have been sufficiently impressed at this time with the short term commissions for judicial officers to embody the principle in its fundamental law. ${ }^{7}$

Following the decision of Chief Justice Marshall in the case of Marbury v. Madison the growth of judicial power was very rapid. By 1818 the power of the courts to pass upon the constitutionality of legislation had become recognized everywhere except in Rhode Island, and judges were eagerly following the lead of the supreme court of the United States in proclaiming the independence of the judicial department. The doctrine of judicial review as stated in 1814 by Justice Woodbury of New Hampshire came to be the

6 Burnet: op. cit., pp. 357-358.

7 Thorpe: p. 1066. 
rule adopted for the guidance of courts in every State. ${ }^{8}$

Obstacles to the realization of the power of the courts to set aside as null and void legislative enactments were encountered in greater degree than elsewhere in those States in which the judges enjoyed the least independence. The Ohio judges who declared unconstitutional an act of the legislature were impeached. Although they were acquitted, the legislature was so indignant because of the assertion of judicial power that they proceeded to declare vacant the offices of the offending judges. ${ }^{9}$ At the same time the house of representatives passed a resolution "that the judges of the supreme court have no right to set aside an act of the legislature, under pretense that the same is unconstitutional." Such power, they held, is neither granted in terms by the constitution nor to be implied from any grant contained therein. To admit the doctrine of judicial review would " render all laws dependent on the arbitrary will, whim, or caprice of the judges, and would necessarily introduce perfect anarchy and

8 Merrill v. Sherburne, 1 N. H. 204.

9 Supra, p. 113. 


\section{THE UNITED STATES}

confusion into the government; destroy its fundamental principles, and subvert every principle of public liberty."10 Despite this remonstrance, not only did the doctrine of judicial review become a part of the constitutional law of Ohio but a new legislature a few years later re-elected for two successive terms one of the deposed judges. ${ }^{11}$

In Georgia, where the judges were chosen by the electorate for the brief term of three years, the supreme court asserted its power in 1815 and set aside an act designed to stay the execution of judgments for the recovery of debts. ${ }^{12}$ The legislature indignantly resented the interference, and denied the right of the judges to question the legality of its acts. But the remonstrance met with a strong dissent in the senate, where it was objected that to deny to the judicial department authority to pass on acts of the legislature "was to confer on the General Assembly the omnipotency of the Parliament of Great Britain; destroy the distinctive char-

10 House Journal (1808-1809), pp. 146-158.

11 Calvin Pease remained upon the supreme bench until 1822.

12 Baldwin: American Judiciary, p. 112. 
acter of the two branches of government; put the legislature above the courts, remove the last check on legislative tyranny and oppression; and leave to the people no other alternative than insurrection or servile obedience to unconstitutional acts." ${ }_{13}$ In Connecticut, where the courts were subordinated to the legislature, there seems to have been only one case of judicial review prior to the adoption of the constitution of $1818 .{ }^{14}$ The dependence of the judges for their places on the annual pleasure of the general assembly caused much dissatisfaction, for the upper house was generally composed of lawyers, whose good will no judge could afford to be wholly unmindful of conciliating. ${ }^{15}$ During this time the legislature exercised a constant supervision over the administration of justice. In 1815 they annulled the judgment and

13 MeMaster: History of the People of the United States, v, p. 400.

14 The Symsbury Case, Kirby 444 (1785). In this ease a legislative enactment making a land grant was not set aside as null and void but was merely given a restricted construction so as to prevent its invading a previous grant.

15 Baldwin: The Three Constitutions of Connecticut, Papers of New Haven Colony Historical Society, v, pp. 226-227. 
set aside the sentence pronounced against a murderer convicted in the superior court. This action is said to have been widely condemned and is believed to have contributed in no small degree to the demand for the adoption of a written constitution. It was an important reform of the constitutional convention of 1818 when it placed the judges beyond the control of the legislature by granting them a tenure during good behavior. ${ }^{16}$

The steady growth of judicial power alarmed those who were anxious to maintain the supremacy of the legislative department. Although they could not deny the necessity of the power of review in the hands of the courts, the opponents of the judiciary sought to find means of restraining its exercise by the judges. Many objected that the judges were become "a class of men set apart, not simply to administer the laws, but who exercise a legislative and even an executive power directly in defiance and contempt of the constitution." ${ }_{17}$ In Congress the fears 16 Trumbull: Historical Notes on the Constitutions of Connecticut (Hartford, 1873), p. 43.

17 Aurora, Jan. 28, 1805. 
of usurpation by "this check department of the government", were vividly depicted. ${ }^{18}$ President Jefferson was bitter in his denunciation of Chief Justice Marshall and declared Marbury v. Madison to be mere obiter dicta which he would refuse to observe as law. ${ }^{19}$ He became so enraged at the outcome of the trial of Aaron Burr that he gave his approval to a proposal to amend the Constitution to limit the tenure of federal judges to a term of years, in order that the courts might be brought under control. ${ }^{20}$

The failure to subordinate the courts to legislative control by the use of the impeachment procedure, together with their inability to secure the adoption of a provision for the removal of federal judges on legislative address, caused the followers of Jefferson great disappointment. They not only disapproved of the course of the judiciary but really believed the freedom from control enjoyed by the judges was fraught with great danger to the government. Tenure during good behavior was assailed as a violation of the fun-

18 Annals, 7th Cong., 1st Sess., p. 552.

19 Works (ed. Ford), ix, p. 53.

20 Ibid., x, p. 387. 
damental principles of American government. In support of this contention, Macon wrote Jefferson :

The great principle of the American governments is election for short periods; yet in most of them it has been departed from in the judiciary. This is attempting to mix principles which cannot be united, that is to make men by the tenure of office independent and upright, who are not so from nature or principle. The tenure of good behavior is a violation of the elective principle. It remains to be determined whether governments uniting two opposite principles will go on smoothly. ${ }^{21}$

Jefferson thought "a judge independent of a king or executive alone is a good thing; but independence of the will of the nation is a solecism, at least in a republic government.",22 At the same time he again urged that future appointments be for four or six years, and renewable by the President and Senate, "in order to bring their conduct at regular periods under revision and probation.",23

Opposition to the exercise of judicial 21 Jefferson MSS., Feb. 2, 1822.

22 Works (ed. Ford), vii, p. 192.

23 Ibid., vii, p. 256. 
power and attempts to abridge the tenure of judges continued to excite only the radical States' rights faction. As early as 1817, it was declared from the supreme bench of South Carolina that "the co-ordinate authority of the judiciary and its right and duty to determine, where its functions involve the question, on the constitutionality of a legislative act, is a point now settled by the judgment of almost every respectable judicial tribunal, and confirmed by the approbation and acquiescence of all wise and sober statesmen in the union.',24 Madison in 1830 in de- . fense of the federal courts declared:

Occasional decisions there have been from the bench which have incurred serious and extensive disapprobation. Still it would seem that, with but few exceptions, the course of the judiciary has been hitherto sustained by the predominant sense of the nation. ${ }^{25}$

So general was the satisfaction with the courts that when the attempt was made in 1831 to secure a repeal of the 25 th section of the judiciary act of 1789 , only fifty-one members of the House of Representatives could

24 Niles Weekly Register, xii, p. 248.

25 Madison MSS., Aug. 30, 1830. 
be found to support the measure. All but six of the fifty-one came from States south of the Potomac and Ohio rivers and were staunch supporters of the doctrines of Thomas Jefferson. ${ }^{26}$

While the proposal to repeal the 25 th section of the judiciary act of 1789 was under consideration, Mr. Lecompte introduced in the House of Representatives a proposition to instruct the committee on the judiciary "to inquire into the expediency of amending the Constitution of the United States, so that judges of the supreme court and of the inferior courts shall hold their respective offices for a term of years." The proposal was rejected by a vote of 115 to 61 . Among those who voted for the resolution are to be found nearly all of the fifty-one who, upon the following day, voted in favor of the repeal of the 25 th section. ${ }^{27}$ In the next session of Congress, Mr. Lecompte again brought forward his proposition, but could muster only twenty-seven votes in its favor. ${ }^{28}$ Further attacks upon the federal judiciary were

26 McMaster: op. cit., vi, p. 61.

27 Debates, 21st Cong., 2d Sess., p. 540.

28 Ibid., 22d Cong., 1st Sess., p. 1856. 
thereupon abandoned, and since that time no serious effort has been made to alter the tenure of judges of the courts of the United States.

I

While the federal courts were becoming established on an independent basis which thwarted all attempts to subject them to legislative control, in the States popular sentiment with regard to the judicial office had undergone a profound change. It has usually been assumed that the wave of democracy which spread over the country after 1824, and which swept Andrew Jackson and his partisans into power, was responsible for the new attitude toward the courts. Judges had for the most part ceased to exhibit the highhanded and arrogant attitude which characterized the colonial judiciary and which a few judges like Addison had sought to adopt in the early State courts. ${ }^{29}$ Yet there was a welldefined feeling in many States that the courts were undemocratic and this was thought due to the long tenure granted the judges which seemed to establish them as a privileged class. At the same time the power of ap29 Supra, p. 46. 
pointment vested in the legislature or in the governor and legislature was subject to great abuse. Although the courts were not without their defenders, it became apparent that the judicial system in many of the States must undergo a complete transformation both with respect to the tenure of judges and the mode of their selection..$^{30}$

This reaction against the judiciary which arose shortly before the middle of the nineteenth century presented a very different aspect from the attacks made on the courts during the first administration of Jefferson. Although it came at a time when legislative power was on the increase, there was no demand for the subordination of the judiciary to legislative control. Leaders of the Jacksonian epoch would have regarded as too centralizing in its effect the political theory so dominant in the earlier period.

In Virginia alone the surviving members of the radical group which had led the assault upon Justice Chase sought the establishment of legislative control. The constitutional convention of 1830 was dominated by the men who had been the active oppo30 Breckinridge: op. cit., p. 42. 
nents of the federal judiciary in 1805. William Branch Giles as governor of the State was a leading figure, as was also John Randolph. Judge Roane, whose pamphlet attacks on the federal judiciary were not less bitter than the political action of partisan friends, was another member. But John Marshall was also present, and, although enfeebled with age, by his calm and logical arguments more than once restrained the fiery Giles.

The view that judges, although commissioned during good behavior, might be legislated out of office by the abolition of their courts was brought forward by Giles. He argued for a power in the legislature to make alterations in the number and organization of the courts regardless of the effect such changes might have upon the incumbents in office. He could not admit that the good behavior tenure guaranteed the judges should in any way fetter the legislature in abolishing a particular court. Judges should continue in office, he thought, only so long as the office to which they had been appointed was permitted to exist. Let the legislature abolish a judicial office and the commission of the 
judge expired with the court. This contention was ably resisted by Chief Justice Marshall, but without avail. The convention by a majority of eight votes refused to provide for the continuance of a judge in office after his court had been modified or abolished. ${ }^{31}$ Thus Giles secured in Virginia the adoption of a theory of judicial office for which he had labored so strenuously in the federal government a quarter of a century earlier.

Elsewhere the demand was for the adoption of such expedients as would render the judiciary more immediately responsible to the people. ${ }^{32}$ Unlimited tenure was declared to promote carelessness, indolence and tyrannical feelings on the part of judges and to beget a want of courtesy to the bar and to the people. ${ }^{33}$ The mode of selection by the legislature or by the governor and the legislature was widely condemned as introducing the evils of party politics into judicial appointments. It was openly asserted that judicial places were become the spoils of partisan conflict and that selections were made not on

31 Debates Virginia Convention, 1830, pp. 726-731.

32 Debates Pennsylvania Convention, 1838, x, p. 181. 33 Ibid., x, p. 211. 
account of ability and fitness but as rewards for political services. To overcome this evil the selection of judges directly by the electorate was declared to be the only remedy. ${ }^{34}$

In the newer sections of the country the reaction against the judiciary may be traced to the attitude of the courts toward the debtor classes. It must be remembered that on the frontier capital was scarce and rates of interest were high. At the same time the legislatures were restrained, either by the federal Constitution or by limitations imposed by the fundamental laws of the States, from offering adequate relief to debtors. The courts in their administration of justice seemed to bear hardly on the poor and to stand as a bulwark to the rich.

The struggle over the judiciary in Kentucky during the twenties is so well known that extended consideration of the situation is unnecessary. $^{35}$ The legislature in 1820 enacted legislation designed to afford an easy method of release from the obligations which

34 See especially Debates Ohio Convention, 1850, i, pp. 66, 67; Debates Maryland Convention, 1851, ii, pp. 461-464.

35 Haines: American Doctrine of Judicial Supremacy, pp. 231-235; McMaster: op. cit., v, pp. 162-166; Breckinridge: op. cit., pp. $78-82$. 
were burdening the debtor class of the State. When these acts were contested in the State courts, they were set aside as being unconstitutional. Vigorous opposition was at once voiced throughout the State, and an attempt was made to remove from office Judge Clark who had handed down the obnoxious decision. Failing in this, the legislature organized a new court of appeals and the issue was taken up by the politicians. The confusion was gradually resolved and the question soon passed out of Kentucky politics. ${ }^{36}$

In Alabama more lasting results followed the outburst of dissatisfaction with the enforcement of legislation affecting the debtor class. Decisions of the supreme court of the State between 1824 and 1830 permitted, under certain conditions, a rate of interest on contracts as high as five per cent. per month and allowed a regular rate of interest at eight per cent. per annum. Much feeling was aroused 36 Collins: History of Kentucky, i, p. 218 et seq. See also Phelan: History of Tennessee, p. 301. In Tennessee the convention of 1834 abolished tenure during good behavior for the judicial office because of the feeling that the judges had become too high-handed and overbearing. This action followed elosely upon two judicial impeachments undertaken by the legislature. 
and repeated demands for changes in the judicial system were heard. ${ }^{37}$ The legislature accordingly in 1830 submitted to the people, and the people approved, an amendment limiting the tenure of office of judges to six years. But it was provided that the judges then on the bench, who had been chosen for unlimited terms, might remain in office until $1833 .^{38}$ This marked the beginning of the movement to limit the tenure of judges of the States to a term of years.

A few years later the supreme court of Maine brought upon itself adverse criticism as the result of an opinion construing acts of the legislature for the relief of poor debtors. $^{39}$ A resolution was passed by the legislature in March, 1839, and submitted to the people in September of that year, providing that "judges should hold office for seven years, if not sooner disqualified.",40 The courts in each instance seem to have decided in accordance with the law, but con37 Henry v. Thompson, 1 Minor 209 (1824); Ellis v. Bibb, 2 Stewart 63 (1829). See also Niles Weekly Register, xv, p. 43.

38 Brown: History of Alabama, pp. 156-157.

39 Knight v. Norton, 15 Maine Rep. 337.

40 Law Reporter, i, pp. 246, 340. 
trary to public opinion. Nevertheless, the course of conduct of the judges was disapproved so generally that it became inevitable that some change in the arrangement of the judicial office would be made.

Dissatisfaction with the courts in a number of the older States arose because of the slowness with which the judges handed down decisions in important cases. Governor Marcy of New York repeatedly called attention to the fact that the courts were at least two years behind with the cases on their dockets. Yet it was admitted that the number of judges on the supreme bench was insufficient to handle the amount of business before them. ${ }^{41}$ The Pennsylvania judges were accused of indolence and a want of sympathy with the popular will, which was attributed to the unlimited tenure granted them by the constitution of 1790. A change to a term of fifteen years was urged in order that they "might return to the virtuous institutions of which they were wrongfully deprived by the act of usurpation of 1790.",42

In the Maryland convention of 1851 both 41 Proceedings New York Convention, 1846, p. 370 et seq. 42 Debates Pennsylvania Convention, 1838, x, p. 193. 
the tenure of office during good behavior and the method of selection by the governor and the legislature were blamed for defects in the judicial system. Unlimited tenure was declared "not consistent with the progressive spirit of the age" and the mode of selection was condemned as having placed upon the bench unfit men. The appointing power was declared to be "a great political engine, by which the interests of a large portion of the people of the State have been sacrificed to the elevation of others." The governor was charged with having "placed on the bench old and infirm men not fit, either mentally or physically, to perform the duties which the constitution or the public exigencies require of them." Seldom, it was asserted, had the appointment failed to depend more or less on the political complexion of the applicant. ${ }^{43}$

Whatever may have been the causes which induced particular States to abolish the tenure during good behavior, the movement spread rapidly throughout the entire country. Following the lead of Alabama, Mississippi in 1832 altered the tenure of judges in that State to a term of six years. Between that 43 Debates Maryland Convention, 1851, pp. 461, 490. 
date and the outbreak of the Civil War in no less than twenty-one States was the term of the judicial office limited to a period of years. ${ }^{44}$ Many of the changes occurred in the new constitutions which were adopted in the western States as they gained admission to the Union. These States uniformly preferred a term of four or six years, but it is a striking feature of constitutional development in the older States that they embodied similar changes in their reconstructed charters.

In not all of the States whose conventions urged changes in the tenure of judges were the people found ready to accept the reforms. The Massachusetts convention of 1853 gave extended consideration to an amendment to limit the tenure of judges of the supreme court to ten years and the measure was finally carried by a large majority. It was the view of the convention that a judge who showed great ability and fitness for judicial office would invariably be re-elected, while a judge

44 Ala. 1830; Miss. 1832; Tenn. 1834; Mich. 1835; Ark. 1836; Pa. 1838; Me. 1839; Tex., La. 1845; N. Y., Ia. 1846; Fla., Mo., Wis. 1848; Cal. 1849; Ky., Va. 1850; Md. 1851; Kan. 1855; Ore., Minn. 1857. 
who had proved unfit might be eliminated. ${ }^{45}$ But the people of the State thought otherwise, and the proposed change was rejected when submitted for popular ratification.

The Massachusetts experience, however, is an exception, for the debates of the few constitutional conventions of the period which are available show a marked preference on the part of the delegates for judicial tenure during a limited term of years. And it was the general practice for popular ratification to stamp with approval the work of the conventions in this respect. Regardless of the causes leading to each proposal to limit the tenure of judges, the practice came into high favor as being in harmony with American ideas and institutions.

The abolition of tenure during good behavior for the judicial office was closely followed by the application of the elective principle in the selection of judges. Frontier life had taught the people the virtues of selfreliance, independence and individuality. They firmly believed in the sovereignty of 45 Address of George S. Boutwell to the People of Berlin (Boston, 1853), p. 12. See also Debates Massachusetts Convention, 1853. 
the people and in the necessity of giving to the mass of the population, as far as possible, the direction of public affairs. ${ }^{46}$ It was declared that since sovereignty is vested in the people the less power they allowed to pass from their hands the better government would prosper.

Popular election was, therefore, hailed as a device highly in accord with the dominant political theory of the day. In the eyes of Jackson and his partisans there was no office to. which the elective principle might not be applied. Expertness and qualification for office were less important considerations than popular interest in government. And popular interest, it was assumed, could only be secured by having the people exercise a direct control in governmental affairs.

The movement to secure the popular election of judges had in most States a sounder basis than that of abstract political theory. Like the reaction against tenure during good behavior the dissatisfaction in many instances rested upon abuses in the existing system. Whether the choice was made by the governor, by and with the advice and consent of ${ }^{46}$ Merriam: American Political Theories, ch. v. 
one branch of the legislature, or by the legislature alone, the rise of political parties had exerted a profound influence upon the selecting authority. In Ohio, where the judges were chosen by joint vote of the two houses, it was said that the legislature had become "a mere political arena, embittering the feelings of party spirit, and corrupting the,pure fountain of justice." ${ }^{47}$ The people of Tennessee in 1853 made their judges elective after a long period of dissatisfaction with the judiciary during which at least two removals on impeachment were effected. ${ }^{48}$ In many of the States where the governor was associated with the legislature in the appointment, nominations were made by caucus of the dominant party and no nomination thus made ever failed to receive the approval of the selecting authority. ${ }^{49}$ Thus not only were the judges removed from popular control but they were in the hands of those who sought to use the judicial office for partisan ends.

${ }_{47}$ Debates Ohio Convention, 1850, i, p. 66. See also Debates Iowa Convention, 1857, i, pp. 227, 263.

48 Phelan: History of Tennessee, pp. 201, 301.

49 Proceedings New York Convention, 1846, pp. 103-104; Debates Kentucky Convention, 1850, p. 168 et seq.; Debates Maryland Convention, 1851, ii, p. 490. 
The adoption of popular election for the judges of the supreme court of Mississippi in 1832 marked the beginning of the change in the mode of selection. Mississippi thus stands as the first State to accept both popular election and limited tenure for judges of the court of last resort. But the application of the elective principle was less easily carried in the States than the abolition of good behavior tenure. It was not until New York in 1846 altered its constitution to give to the people the choice of judges that the expedient of popular election secured widespread acceptance. With the leading State in the Union in the advance, no less than seventeen States in the following eleven years gave to the electorate the choice of judges. By 1857 an elective judiciary was declared to be the type most desirable for the States, ${ }^{50}$ and at the beginning of the Civil War the system stood in nineteen of the thirty-four State constitutions. ${ }^{51}$

The alteration of the judicial system in 50 Debates Minnesota Convention, 1857, p. 495.

51 Ga. 1777; Miss. 1832; N. Y. 1846; Wis. 1848; Cal. 1849; Ky., Mich., Mo., Pa., Va. 1850; Ind., Md., Ohio 1851; La. 1852; Tenn. 1853; Kan. 1855; Ia., Minn., Ore. 1857. 
most of the States was completed without serious opposition. The more conservative States which refused to change either the tenure of judges or the mode of their selection were greatly in the minority, including mainly the smaller States of the Atlantic seaboard like Connecticut, New Hampshire, New Jersey and Delaware. But in them no great dissatisfaction with the courts was evinced nor did popular opinion crystallize in favor of radical governmental changes of any kind. Nevertheless there were many who predicted that evil effects would result from the innovations, and one critic of the New York constitution of 1846 thought "that before many years another convention would be called to reform some of the late reforms." ${ }_{52}$ This prophecy was fulfilled when, in 1876, an amendment was passed lengthening the term of the New York judges from eight to fourteen years. ${ }^{53}$ In Pennsylvania the term of eight years provided by the constitution of 1838 was found equally unsatisfactory, and was extended in 1873 to twenty-one years with a provision rendering the judges ineli52 Law Reporter, x, p. 95.

53 Thorpe: p. 2693. 
gible to re-election. ${ }^{54}$ The marked tendency in constitution making since the Civil War has been to extend the tenure of State judges. This has been done in eight States, where the changes have resulted in lengthening the term from four to six years. ${ }^{55}$ The average term has thus been increased from four to seven years to from eight to fifteen years.

The selection of judges by direct vote of the people has continued in vogue in every State but one where it has once secured adoption. Georgia in 1865 abandoned the choice of judges by popular election in favor of their selection by joint vote of the two houses of the legislature. ${ }^{56}$ Immediately after the Civil War, Mississippi, Louisiana, and Texas in framing new constitutions vested the choice of judges in the governor, but all have now returned to the mode of popular election. ${ }^{57}$ The same evils that arose

54 Thorpe: p. 3133.

55 Miss. 1868; Pa. 1873; Mo. 1875; N. Y. 1876; Wis. 1877; Cal., La. 1879. Connecticut in 1876 limited the term of judges to four years but extended it in 1880 to eight years.

se Thorpe: p. 818.

${ }^{57}$ Mississippi in 1868 adopted the appointive system but abandoned it in 1914. Louisiana in 1864 adopted the ap- 
under the indirect methods of selection have developed under the system of an elective judiciary. Politicians have manipulated the popular elections as easily as they once directed the balloting in the legislatures or coerced the governor of a dominant party in making an appointment. Non-partisan ballots and the separation of judicial from the general elections have reduced but have not destroyed partisan control of the mode of selection.

All attempts to supplant the mode of popular election for the choice of judges have failed. The New York constitutional convention of 1915 gave extended consideration to proposals to vest the choice of judges in the governor alone. The members of the legal profession from the urban districts at least favored an appointive judiciary. But the laity, especially in the rural districts, appeared irrevocablý opposed to any change in the mode of selection. The professional politicians were equally vigorous in their opposition to the adoption of the pointive system but returned to choice by popular election in 1904, while Texas retained the appointive system from 1868 to 1876. 
appointive system. The Tammany Society presented a memorial in which they declared "the power of selecting judges should never be placed in the hands other than those of the people themselves." ${ }^{58}$ After the subject had been fought out in the convention the friends of the appointive judiciary conceded that victory, if it ever comes to them, will be in the remote future. ${ }^{59}$

The selection of federal judges by any other means than that now in vogue has generally been regarded as impracticable. During the first ninety years of our history only four propositions were introduced in Congress looking toward any change in the mode of selection. ${ }^{60}$ In recent years a few resolu-

58 Record New York Convention, 1915, i, p. 370.

59 See proposition of the New York Short Ballot Association offered as a compromise. The plan provides for nonpartisan ballot with nominations by petition. But the governor is permitted to make one nomination for each judicial office. After the name of each person so nominated the ballot will bear the words "Recommended by the Governor." It is expected that the governor's selection under this system will be good enough to escape serious eriticism and will go through to a unanimous election unopposed. The prestige of the governor's backing, it is thought, will be of benefit to his nominee and thus discourage unwarranted opposition. ${ }^{60}$ Ames: Proposed Amendments to the Constitution, pp. 146-147. 
tions have been introduced designed to provide for the election of judges of the inferior courts by the voters in the several judicial districts, but none of the measures has received serious consideration. ${ }^{61}$

\section{II}

Age limits at which judicial officers must retire have never been popular in American governments. The first constitution of New York provided for the retirement of judges at the age of sixty years, but Hamilton "believed there were few who did not disapprove of this provision." ${ }^{82}$ Although he thought the danger from a superannuated bench purely imaginary, the clause was retained and forced the retirement of Chancellor Kent at the height of his mental vigor. An amendment was then passed placing the age of retirement at seventy years. For a time the expedient of an age limit for the judicial office seemed to meet with favor. Mississippi, Alabama, and Missouri placed limitations in their first constitutions which provided that ${ }^{61}$ See for example 63d Cong., 1st Sess., H. J. Res. 17. 62 Federalist, lxxix. 
no judge should be appointed to, or continue in, office after he had reached the age of sixty-five years. But the only States which have continued to follow the example set by New York are Connecticut and Maryland. In both of these States the age of retirement from the judicial office is fixed at seventy years. ${ }^{63}$

The adoption of the principle of retiring judges at the age of seventy was advocated both in the Virginia convention of 1829 and in that held in Massachusetts in 1853. In neither convention was the measure successful in passing, although it found warm supporters in Virginia. The argument for the proposal rested on the ground that the remedy of removal on address being the only means of ridding the bench of superannuated judges, great danger threatened the commonwealth. But remembering the services of Wythe, Pendleton, and Roane, who had adorned the supreme bench in Virginia long after they would have been retired had the age limit in vogue in New York prevailed, 63 Thorpe: pp. 543, 1727. 
the convention rejected the proposed alteration. $^{64}$

Several attempts have been made to prescribe an age limit for federal judges. The first of these was in 1809 in connection with a proposition to have the judges removable on address, and proposed that judges should not continue in office after they had attained the age of sixty-five years. A second attempt was made in 1826 by Mr. Eastman of New Hampshire, who sought to have the judges retire upon reaching the age of seventy years, and in 1835 a motion was made " to inquire at what age judges shall be rendered incompetent to serve."

After the close of the Civil War the agitation for the adoption of age limits for the retirement of federal judges was renewed. On February 13, 1869, Mr. Ashley in the House of Representatives offered a resolution proposing as an amendment to the Constitution that judges should hold office for twenty years, retire at seventy years of age,

${ }_{64}$ Debates of the Virginia Convention, 1829-1830, pp. 731-740.

65 Ames: op. cit., p. 152. 
and receive a pension. In explanation of his proposal, he said:

I wish the court were what it ought to be now. If gentlemen will take the trouble to go into the supreme court they will find there men passing upon questions of the gravest magnitude who are utterly unfit for the discharge of such responsibilities and important duties as are almost daily devolving upon them. It is well known that for some time before Judge McLean's death his associates on the bench at the request of friends relieved him of all responsible labor in the preparation of opinions. Though sleeping upon the bench during the greater part of the time the court was in session, and dying with age, he was almost daily voting upon questions of the gravest character. ${ }^{66}$

The contention of Mr. Ashley that the supreme bench was encumbered with judges who had outlived their usefulness everyone was willing to believe when, in the following year, Justice Greer was forced to resign by his colleagues because he was no longer able to consider intelligently the questions which came before the court. The inconsistent behavior of the judge in attempting to change

6e Globe, 40th Cong., 3d Sess., App., p. 210. See also an article by Mr. Ashley in the Arena for October, 1895. 
his vote on the Legal Tender Cases confirmed the belief that he had become so aged and infirm as to be unable to understand the question on which he was voting. Every judge on the bench thereupon expressed to him the opinion that he should resign. ${ }^{67}$

The possibility of a federal judge remaining upon the bench after he has become unfitted by age for the performance of judicial duties has been reduced by the act of April 10, 1869, which provides that judges of the courts of the United States may retire on full pay at the age of seventy years, after ten

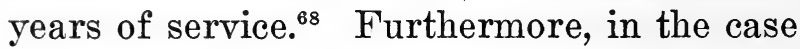
of justices of the supreme court, Congress has been ready to vote a pension to incumbents who have been stricken with serious illness and have been unable to perform the duties of their office even though they had not reached the age limit nor attained the years of service required by the act of 1869 . This was done in 1910 in the case of Justice Moody, and the precedent would unquestionably have been followed more recently in the 67 J. P. Bradley: Miscellaneous Writings, pp. 73-74. 68 Revised Statutes (1878), Sec. 714. 
case of Justice Lamar had death not overtaken him before Congress could act.

Notwithstanding the provisions thus made by the act of 1869 for the voluntary retirement on full pay of federal judges, some incumbents have retained their places after they have lost the vigor necessary to successful judicial service. Attorney-General McReynolds in 1913 thought the evil which resulted from the presence of superannuated judges upon the bench so great as to require the attention of Congress. He recommended that where a federal judge does not retire voluntarily at the age of seventy, after ten years' service, it shall be the duty of the President to appoint another judge, who shall preside over the court and have precedence over the older judge. This, he thought, would insure at all times the presence of a judge sufficiently active to discharge promptly and adequately the duties of the court. ${ }^{69}$

The recommendation of Attorney-General McReynolds was reaffirmed in 1914 and 1915 by his successor, Mr. Gregory, and became the basis of a bill introduced in Congress by 69 64th Cong., 1st Sess., Senate Rpt. 21. 
Senator Hoke Smith. ${ }^{70}$ The proposal of Mr. Smith sought to give the President discretionary power, "when in his opinion the public good requires," to appoint a new judge to take up the duties of a judge who has become too aged or infirm to perform useful service. The measure was at once challenged by the Republican members of the Senate as a partisan attempt "to create seventeen new judgeships for deserving Democrats." Whatever may be the fate of this and other proposals to place age limits upon the federal judges, the committee investigation has apparently shown that there are more superannuated judges upon the bench than was generally supposed. ${ }^{71}$

The marked differences in the tenure and mode of selection of State and federal judges has, of course, had a great influence in determining the character of the two judicial systems. It has frequently been assumed that the State courts are much inferior to those of the nation. That this has not always been

70 Record, 64th Cong., 1st Sess., pp. 60, 3154-3158. This proposal affects only the circuit and district court judges, the justices of the supreme court remaining untouched.

71 See also Taft: Popular Government, pp. 158-161. 
true has been a matter of some surprise to European observers of our political institutions. The greater importance which attaches to a federal place would lead one to look for the ablest men in the service of the nation. But the federal judiciary has set a standard to which public opinion has compelled the State courts to conform. Neither inefficiency in the administration of the law nor any lapse from judicial dignity will long be tolerated in a community whose people have an honest interest in their government. The influence of public opinion goes far to promote the success of the judiciary in the American States. $^{72}$

72 Nerinex: L'Organisation Judiciare aux États-Unis, pp. 414-421; Bryce: American Commonwealth, i, pp. 546-549. 


\section{CHAPTER V \\ CONCLUSIONS}

The independence of the judiciary so necessary to the success of government in the United States requires that this department shall rest on the sure basis of the Constitution. Security of tenure, freedom from legislative and executive control and from merely temporary political changes are considerations of great importance. In England the independence of the judicial office is secured because the judges have been brought under the direct control of the Parliamentary sovereignty. They are amenable for any misconduct to the sovereign and may be controlled by whatever procedure Parliament sees fit. The sovereignty of Parliament being undisputed, the judges have no power to stay its judgments. Even though an act of Parliament be against common reason or abridge the fundamental rights of Englishmen, no power vests in the courts to set it aside as 
null and void. "True it is," declared Blackstone, "that what the Parliament doth, no authority upon earth can undo." "1

In the United States, however, government has been established upon a basis of a separation of powers. Sovereignty rests with the people who delegate the functions of government to three co-ordinate and independent bodies. At the same time the function, not of controlling the other departments of government, but of defining the separation and limits of their power has devolved upon the judiciary, and "this function and duty of the judiciary distinguishes the American system from all other systems of government. The perpetuity of our institutions and the liberty which is enjoyed under them depend in no small degree upon the power of the judiciary to declare null and void all legislation that is clearly repugnant to the supreme law of the land." 2 The judiciary in the United States does not sit as the full representative of the sovereignty but shares with the other branches of the government the exercise of powers delegated to it and restricted by the

1 Commentaries, i, p. 161.

2 Smyth v. Ames, 169 U. S. 528. 
Constitution. It has thus come about that the behavior of the judges has been subjected to conditions and limitations elsewhere unknown in modern governments.

In the United States the judge has a double rôle. In the first place he is the officer of the government in whom is vested the judicial power and whose business it is to administer justice. In this capacity all will admit the necessity of his independence. He becomes not a servant of the people but "an umpire in the game of litigation. Unless our judges are independent and protected against popular clamor and the demands of political changes, they cannot perform their duty to the people, in the administration of justice for the people.",3

In addition to this customary function of the judicial office, the judge in the United States has become the guardian of the Constitution. To determine whether an act of the legislature is in harmony with the written constitution, and to refuse to recognize as valid any enactment made ultra vires, has been declared to be the very essense of judicial duty. This power in the courts has for 3 Judson: Judiciary and the People, p. 252. 
a long time been a well-recognized principle and one which has received popular acceptance. The supreme court has declared that "the judicial duty of upholding the provisions of the Constitution as against any legislation conflicting therewith has become now an accepted fact in the judicial life of the nation.", This power, the judges have been very careful to explain, is not to be exercised unless legislative enactments brought before them are plainly in contravention of some constitutional principle. Justice Moody, in his dissenting opinion in the Employers' Liability Cases, said: "The court has never exercised the power of declaring the acts of a co-ordinate branch of the government void except where there is no possible and sensible construction of the act which is consistent with the fundamental organic law. The presumption that other branches of the government will restrain themselves within the scope of their authority, and the respect

4 Fairbank v. U. S., 181 U. S. 286. Georgia has embodied in the constitution the specific provision that all legislative acts in violation of the constitution, or of the Constitution of the United States, are void and the judiciary shall so declare them. Georgia Code, 1911, Sec. 6392, p. 1478. Constitution, Sec. iv, par. ii. 
which is due to them and their acts admit of no other attitude from this court. But the economic opinions of the judges and their views of the requirements of justice and public policy, even when crystallized into wellsettled doctrines of the law, have no constitutional sancity. They are binding upon succeeding judges, but while they may influence, they cannot control legislators. Legislators have their own economic theories, their views of justice and public policy, and their views when embodied in written law must prevail.",5 Thus the doctrine of judicial review implies only the power and duty to insure the supremacy of the constitution and to refuse recognition to any law purporting to be enacted within constitutional authority, but in fact beyond the power delegated to the legislative branch of the government.

Nevertheless, it is precisely because of his possession of this latter function that the demand arises for the political responsibility of the judge. In this capacity the judge has come to exercise an important power of determining public policy, and, it is insisted, no official whose duties involve the determi5207 U. S. 433. 
nation of public policy should be free from popular control. One advocate of this view has declared:

Perhaps the most important influence in bringing about a demand for a greater popular control of the courts is the increasingly important position which the courts have come to exercise as political organs of the government, through their power to declare laws unconstitutional as violative of the guaranties of "due process of law" and "equal protection of the laws." These guaranties mean whatever the courts in any particular case may decide that they mean, and furnish a broad foundation upon which the courts may base declarations of unconstitutionality. As has been frequently suggested in recent years, the courts have become practically legislative organs, with an absolute power of veto over statutory legislation which they may regard as inexpedient; and this power has been used most frequently with respect to social and industrial legislation enacted to meet new social and economic conditions. ${ }^{6}$

This position the advocates of the popular recall have accepted, and from it argue that the judges have become legislators and

6 W. F. Dodd: Michigan Law Review, x, p. 85; Gilbert Roe: Our Judicial Oligarchy, p. 216. 
should be considered as such in our governmental machinery.

It is, however, no ground for depriving the judicial office of its constitutional safeguards that judges have powers which cannot be stated with precision or crystallized into hard and fast rules of conduct. It may be expected that the courts will endeavor to lay down rules of law which are mutually harmonious, extending these rules by analogy. And this is exactly what has been done. The United States Supreme Court has declared in favor of ascertaining the intent and application of the "due process of law" clause in the federal Constitution "by the gradual process of judicial inclusion and exclusion, as the cases presented for decision shall require, with the reasoning on which such decisions may be founded." What interpretation is to be placed upon the terms "due process of law" and "equal protection of the laws" cannot be determined in the abstract. The rule of reason alone governs. If it becomes incumbent upon the court to pass judgment upon legislation the validity of which is challenged as effecting a deprivation of life, liberty or 7 Davidson v. New Orleans, 96 U. S. 97. 
property without due process of law, it must consider the reasonableness of each case. ${ }^{8}$

That a much greater burden has been thrown upon the courts since the Fourteenth Amendment was written into our Constitution must be admitted. Between 1868 and 1911, six hundred and four decisions were handed down by the Supreme Court of the United States alone interpreting the first section of the amendment. And the doctrine of stare decisis has not resulted in the crystallization of these opinions into definite rules of interpretation. When all is said, there remains a broad discretion in the courts, and the "essential elements of due process of law, already established by them, are singularly few, though of wide application and deep significance.",9

A tremendous expansion of the doctrine of judicial review has been apparent for the past twenty-five years. As one writer has pointed out: "The legislative activity of American courts which has resulted from this extension of the right of review has now

8 Collins: The Fourteenth Amendment and the States, ch. viii.

9 Twining v. New Jersey, 211 U. S. 78. 
become a commonplace fact of our political thought." ${ }^{\prime 0}$ Toward this view the modern interpretation put upon due process of law has contributed in no small degree. But this growth of judicial power has involved nothing more than the advance of constitutional limitations along lines the extension of which is fully within the scope of judicial authority. There is here involved no question of mere administration where the responsibility is purely political and where an appeal should be made to the ultimate tribunal of the public judgment, exercised either in the pressure of of opinion or by means of the suffrage. "The fundamental rights to life, liberty, and the pursuit of happiness are secured by those maxims of constitutional law which are the monuments showing the victorious progress of the race in securing to men the blessings of civilization under the reign of just and equal laws, so that, in the famous language of the Massachusetts Bill of Rights, the government of the commonwealth 'may be a government of laws and not of men.' For, the very idea that one man may be compelled

10 Haines: The American Doctrine of Judicial Supremacy, p. 309 . 
to hold his life, or the means of living, or any material right essential to the enjoyment of life, at the mere will of another, seems to be intolerable in any country where freedom prevails, as being the essence of slavery itself. ... .",11

Judicial legislation was not unknown before the adoption of the Fourteenth Amendment. More than a century ago the United States Supreme Court began the task of defining the obligation of contracts, the regulation of commerce, and other powers conferred on the federal government, or limitations imposed upon the States. Today this work cannot be said to have been finished. Nor should it be a matter of surprise, much less of bitter denunciation, that the courts have not stereotyped through the paralyzing doctrine of stare decisis their opinions upon these important questions. The doctrine of stare decisis will always remain in constitutional law much weaker than elsewhere. Constitutional law is organic and must grow to meet the demands of changing social and economic conditions. In a recent address before the New York Bar Association, Lord 11 Yick Wo v. Hopkins, 118 U. S. 356. 
Reading declared that the English judges are endeavoring to get rid of the doctrine of stare decisis in the ordinary civil law and to decide cases on principle. ${ }^{12}$ When judges feel the need of overcoming this barrier in applying the common law, it is safe to prophesy that in a branch of law that touches public policy at as many points as does constitutional law the doctrine of stare decisis cannot endure.

The supremacy of law established by the courts and the demarcation by judicial authority of the scope and limits of the functions of the several departments of government remain fundamental features of our system. Those who argue that court decisions are mere matters of opinion as to the wisdom of legislative enactments or as to prevailing views of morality proceed upon a false conception of the basis of constitutional power. Courts do not decide laws void because unwise; they only declare them void because in conflict with the constitution. To ascertain whether an act is in harmony with the constitution is a question which depends upon technical matters of law and fact, which 12 New York Times, Oct. 15, 1915. 
can be determined efficiently only by experts. That the courts do not always have the necessary machinery to examine fully such questions may be admitted. But it is equally true that the courts can be established as expert fact-determining agents, while it is certain that no such expertness can be expected of the electorate. It does not involve any question of popular rule, but rather how may be secured the most efficient government and the faithful observance of the law.

Security of tenure for the judicial office becomes all the more important because of this increase in the burden cast upon the courts. To the end that he may administer justice without fear or favor the judge should be given a tenure independent of all political or personal or temporary considerations. The demands upon our legislative assemblies increase day by day. Congress, as well as the State legislatures, may be observed pushing their legislative power closer to the line of their constitutional authority. The number of cases in which the limits of such authority are necessarily involved must also increase. "Occasionally a court finds that some new experiment in legislation or 
in administration contravenes some longestablished limitation upon legislative or executive power, or finds that some crudely drawn statute is inadequate to produce the effect that was expected of it, or enforces some law which has unexpected results." "13 Irritation and impatience toward the courts is the result.

Popular dissatisfaction with the courts would hardly disappear even if they were deprived of the power to pass upon the constitutionality of statutes. It would still remain the duty of the courts in the interpretation of statutes to ascertain the meaning intended by the legislature. Statutes cannot interpret themselves; their meaning must be declared by the courts. If legislators are careless in the drafting of their acts, leaving to the judges the refinement of their product, it must often follow that what is declared by the courts to be law is very different from that which was originally intended by the legislature.

The necessity of maintaining undiminished the power of a really independent judiciary is 13 Root: Judicial Decisions and Public Feeling, 62d Cong., 2d Sess., S. D. 271. 
apparent regardless of the continuance of the doctrine of judicial review. To heed the appeal to passion and prejudice and hatred is to make way for the destruction of order. As Mr. Root has said: "The first duty of popular self-government is individual selfcontrol.' Not merely the preservation of those inalienable rights guaranteed by the Constitution but the rule of law as well demands the security of the judicial office.

\section{I}

It has been argued that logically both the selection and the removal of judges ought to be vested directly in the electorate. But practical difficulties interpose themselves in the adoption of such procedure. The framers of the federal Constitution never considered so radical a departure. Indeed, the proposal to vest the selection of judges in the national legislature was tabled because "experience has shown the impropriety of such appointments by numerous bodies." "14 Even to vest the selection in one branch of the legislature was opposed as likely to become a "mere 14 Parrand: i, p. 232. 
piece of jobbing." 15 In order to secure personal responsibility in the selection of judges, Edmund Randolph thought the respective votes of members of the Senate ought to be entered on the journal. ${ }^{16}$ Although not all members of the convention were agreed upon the exact mode of selection, it was uniformly thought unwise to leave the choice of judges with any authority administered by a number of individuals. ${ }^{17}$

Hamilton in the Federalist suggested that in a half century the House of Representatives might consist of three or four hundred persons, and "a body so fluctuating and at the same time so numerous can never be deemed proper for the exercise of the power of appointment.' At the same time he condemned the selection of officers by a council of appointment, the method then in vogue in New York, where the governor and three other men in secret conclave offered unbounded field for cabal and intrigue. ${ }^{18}$ The idea of election by the people at large, he

15 Farrand: ii, p. 41.

16 Ibid., ii, p. 80.

17 Ibid., ii, p. 81.

18 Federalist, lxxvii. 


\section{THE UNITED STATES}

declared, "will be readily admitted to be impracticable; as waiving every other consideration, it would leave them little time to do anything else." 19

Popular election of officers, now so general throughout the United States, has resulted in many places in the evil which Hamilton foretold. The burden thrown upon the electorate in choosing among a host of candidates those best fitted for office has been so great that the system has broken down. It has been fully recognized for a long time that the voter is not a free agent in the selection of the officers of government but has come to rely upon the advice of the professional politician who really determines the choice and calls upon the electorate to ratify his work. But so strongly has the political party become entrenched that almost all efforts to withdraw from its grip the control even of the judicial offices have been in vain. ${ }^{20}$

If we examine the history of our State courts there would seem to be little connection between the mode of selection and the 19 Federalist, lxxvi.

20 Kales: Unpopular Government in the United States, chs. ii, xvii. 
responsibility of the judge. It is undoubtedly true that only where the influence of the bar associations can be felt in the selection of a judge can there be an adequate guide afforded for the discovery of the relative merits of the candidates who offer themselves for places upon the bench. It is important that legal ability, success at the bar, and personal character rather than political activity and influence shall determine the selection of a judge. But all of the weaknesses which have been charged against a judiciary elected by the people are to be found in those courts which have been chosen by legislative or executive appointment. ${ }^{21}$

It has been claimed that an appointive judiciary is superior to a bench chosen by popular vote. Indeed, a comparison has been made between the work of present-day judges in the several States with that of the judiciary prior to 1850 in an effort to prove that recent courts have shown a decline in constructive law-making. This decline, it has been asserted, has been due to the method of selection of the judges. ${ }^{22}$ It would be very

21 Supra, p. 171.

22 See the report on Efficiency in the Administration of 
interesting if proof could be shown in support of this contention. But a most exhaustive study would be necessary to arrive at accurate conclusions. Conditions have changed since 1850, and it is doubtful whether any court, no matter how chosen, could deal with the complex problems of the present day with the results attained by the courts in the socalled classical period of American law.

Any attempt to draw inferences in favor of an appointive bench is certain to be subject to notable exceptions. It must be admitted that in many States a judiciary of the highest order has been maintained by popular election. ${ }^{23}$ Not all popularly elected tribunals have shown the illiberal tendencies to be marked in the decisions of the elective courts in New York and Illinois. ${ }^{24}$ The supreme court of Wisconsin, an elective bench, Justice, prepared in 1914 for the National Economic League by Charles W. Eliot, Moorfield Storey, Louis D. Brandeis, and Roscoe Pound.

23 Taft: Popular Government, p. 190.

24 In Ives v. South Buffalo R. R. Company, 201 N. Y. 271, workmen's compensation legislation was overturned. In Ritchie v. State, 155 Ill. 98, an act limiting the hours of labor for women was set aside. The Illinois court later upheld the constitutionality of such legislation. Ritchie v. Wayman, 244 Ill. 509. 
in passing upon the subject of workmen's compensation legislation handed down a decision as trenchant and as enlightened as the pronouncement of any appointive court. ${ }^{25} \mathrm{~A}$ mediocre bench is almost certain to be technical and, in questions of constitutional law, strict and reactionary. But it would be unfair to say that in every State where the choice of judges has been entrusted to the people the judiciary is characterized by mediocrity or that it is in every case inferior to an appointive bench.

The method of selecting judges is perhaps best determined by local conditions. The general conclusion to be drawn from "reports and opinions of leading lawyers throughout the country is that the character and ability of the bench are governed, practically, by the tone and demands of the average public sentiment in a given locality, rather than by the particular system through which such sentiment asserts itself." ${ }^{26}$ In Vermont, where the supposedly discredited system of legis-

25 Borgnis v. Falk Co., 147 Wis. 327.

26 See the report of Simon Fleischmann: Influence of the Bar in the Selection of Judges, Proceedings of New York State Bar Association, xxviii, pp. 60-130. 
lative appointment is in vogue, the judiciary is one of the most satisfactory in the country. Although appointments are made for but two years, public opinion has long since taken a firm stand so that judges are, as a matter of course, re-elected from term to term during life. Rhode Island with the same system has a much weaker bench, since members of the legislature are frequently chosen without regard for legal ability or personal character. Like contrasts are to be found in the States in which the judiciary is appointed, as well as in those in which it is popularly elected. In Wisconsin the elective judiciary has achieved unusual distinction. Chief Justice Winslow of the Wisconsin supreme court, speaking of the Wisconsin system, said:

I would claim no exceptional ability or wisdom for the Wisconsin electorate, but I do claim that remarkable results have been reached in the line of removing the bench from party politics, results which it will be found difficult, if not impossible to parallel in any of our States.

It is a remarkable fact that while Wisconsin was one of the pioneer States in the full and complete adoption of the elective system, its supreme court has been exceptionally free from violent and fre- 
quent changes. During the entire history of the separate supreme court from its organization in 1855 to the present time, it has had but twenty-five judges. Since a very early period in the history of Wisconsin, with a single recent exception, no sitting justice of the supreme court who has been a candidate for re-election has been defeated, notwithstanding a number of attempts in that direction, and judges who have reached that bench have been given practically a life tenure. This result is principally due to a sentiment which has slowly crystallized among the people of the State to the effect that judges of that court should not be nominated by political parties and that a sitting judge who has performed his duties faithfully should be retained during his years of usefulness, regardless of his opinions. ${ }^{27}$

While public opinion can be shaped so as to secure wise selections by the electorate, there is a strong tendency to undervalue the services of experts in our government. ${ }^{28}$ But the judicial office is one which requires a high degree of expertness for its proper administration. For this reason it is important that the bar be able to make its influence felt by

27 Kansas Bar Association Proceedings, 1914, pp. 43-44. 28 Hadley: Undercurrents in American Polities, pp. 171177. 
the selecting authority and that judges be given secure tenure. It is not enough that bar associations have opportunity to stamp with their approval the aspirants for judicial places. We should have a special class of men from whom the best-equipped judges may be selected. In England the legal profession is made up of solicitors, who prepare papers, and barristers or advocates, who argue cases in the courts. It is from this latter class that the judges are recruited. ${ }^{29}$ In the United States no such special group is available. Our judges are selected from the mass of lawyers in a given community. It makes no difference whether the selection is by the county central committee of the dominant party, or by the self-serving petitions under primary laws, or by the State executive. All are eligible who have passed the bar examinations. Most lawyers have spent their time in client care-taking and, upon their elevation to the bench, must learn the art of conducting trials from the beginning. It is impossible to expect from such men, no matter how they are chosen, the expert knowledge of the rules of law and of ${ }^{29}$ Lowell: The Government of England, ii, pp. 468-470. 
practice that would be gained by a long experience in handling litigated problems in the courts. $^{30}$

But much more important than the method of selection is the problem of guaranteeing judges in office security of tenure. To leave the judge dependent upon the caprice of a temporary majority in the community is to deprive him of every safeguard in the administration of justice. In such a situation few men would have the courage to decide against the majority when justice and law require. Nor would his independence be adequate if his tenure in office depended upon the will of the legislature.

The framers of the federal Constitution rejected the procedure of removal on address in the belief that it was inconsistent with the necessary independence of the courts. In England the expedient has proved almost impossible of practical use, although its presence in the British constitution has doubtless served to remind judges of the responsibility under which they act. ${ }^{31}$ The failure of attempts in England to effect a

30 Kales: Illinois Law Review, iv, pp. 316-317.

31 Hearn: Government of England, pp. 82-89. 
removal on address has been due in nearly all cases to inability to define the source of power and the scope of the authority of the two houses of Parliament to undertake such proceeding. One view has been that such proceedings are judicial in character, governed by lex terrae, where the accused is entitled to be heard, may employ counsel, and where the rules of evidence are strictly observed. The other view maintains that the procedure is discretionary with the houses, and an address may be voted for any or no reason. Thus it is an act of power, and the procedure is entirely under the control of the houses of Parliament,-a part of lex parliamenti. ${ }^{32}$

In theory the latter view has prevailed, and many touching references have been made to the direct control of the sovereignty over the English judges. But in practice no attempt has been made to remove a judge on address without granting him all the rights and privileges accompanying a judicial proceeding. The most serious consideration is given charges against the judges, and on more than 32 McIlwain: Tenure of English Judges, American Political Science Review, vii, p. 225 et seq. 
one occasion members of both houses of Parliament have been sharply called to order for reflecting upon the judges in their judicial capacity. When in 1861 the Earl of Leitrim brought vague charges against Chief Justice Monohan in the House of Lords, he was severely scored by members. The lord chancellor pointed out that it would be entirely proper to move an address but he hoped the lords would not permit any member to bring forward such charges without giving the defendant an opportunity to be heard. ${ }^{33}$

The American commonwealths which have adopted the expedient of removal on address have found it impossible to operate except as a substitute for the impeachment procedure. It would be inconsistent with our system of government to adopt any form of removal which did not operate in accordance with the law of the land. When we do not allow a criminal to be convicted except by a jury sworn to decide the case according to the law and the facts, it would be tragically grotesque to allow a public officer to be condemned when he has had no opportunity to be heard in his 33 Hansard: Debates, elxiii, p. 900. See also Parliamentary Debates, 5th Series, xli, p. 2779. 
own defense. It has, therefore, been the practice in most cases before voting an address to hold an inquiry in every way analogous to a judicial proceeding. Even in Massachusetts, where the language of the constitution leaves no doubt as to the unlimited power of the legislature to address the governor for the removal of a judge, it has been the settled practice to grant the accused a hearing, summon witnesses in his defense, and to observe the established rules of evidence. ${ }^{34}$ Although in theory many of the judges in our State courts hold their offices removable on joint address of the two branches of the legislature, in practice it has become impossible to effect any such removal without a procedure more costly and more cumbrous than that of impeachment. One may easily agree with Professor McIlwain that the federal convention showed great wisdom when they followed the suggestion of James Wilson and omitted the expedient of removal on address from the Constitution. $^{35}$

34 See Foster on the Constitution, Appendix, for a description of most of the removals from judicial offices in the several States.

35 Loc. cit. 
That we have improper judges must be admitted. But weaknesses in the judiciary spring either from incompetence or from corruption. The incompetent judge is invariably the result of unwise selection. Want of ability, lack of judicial temperament, and a natural inaptitude for judicial service are faults which can be discerned if care be exercised in the selection. The corrupt judge, however, is often the product of circumstances impossible to forecast. In his case a speedy removal from office becomes necessary in the interest of the community. But whether a judge be incompetent or corrupt is a question of fact to be determined only upon a careful review of all the evidence in the case. Only such procedure as will permit a careful survey of all the facts in a given case before removal will be found consistent with the proper independence of the judiciary.

\section{II}

The sufficiency of the impeachment procedure to protect the people against the evils of an incompetent or corrupt judiciary has been vigorously challenged. It has been de- 
clared that experience has shown the machinery of impeachment to be cumbrous and unduly difficult of utilization. In these claims there is a large element of truth. However, it has become manifest not that a substitute method of procedure should be made available, but that efforts should be bent toward the simplification of the constitutional remedy.

The experience of England and America is against the expedient of removal on legislative address. The only really effective removals have been those secured through the use of the impeachment process. Recourse to the use of the impeachment clause has been by no means as frequent as was expected by the framers of the Constitution. They looked forward to trials upon articles of impeachment as not unusual. That we have so seldom brought offenders to the bar of the Senate has been due to the narrow construction placed upon the constitutional provision. But this the Senate has now overcome, and under the ruling in the Archbald case the stock arguments against the impeachment process lose much of their force.

Several propositions to alter the impeach- 
ment procedure with a view to the saving of time and expense have recently been brought forward. While the Archbald trial was in progress a resolution was offered authorizing the Senate "to make such amendments and additions to the rules of impeachment, except in the case of President, Vice-President, members of the Cabinet, and the Supreme Court, as would enable testimony to be taken by the judiciary committee and the findings of fact be reported to the Senate." ${ }^{36}$ Such procedure would be similar to the taking of testimony in a court of equity, the judiciary committee of the Senate acting in the capacity of master. But the proposal met with objection on the ground that such method would not be impressive.

The apparent ease with which the conviction of Judge Archbald was secured called even greater attention than before to the undue amount of time spent by the Senate in hearing witnesses and disposing of details in connection with the determinations of fact. One senator remarked that "it was like bringing out a steam roller to crush a toad." Senator Pomerene suggested that power be 30 62d Cong., 3d Sess., S. Res. 412. 
given Congress "to provide for other means of impeaching civil officers, except the President, Vice-President, and the Supreme Court." ${ }^{37}$ At the same time a resolution was introduced into the House of Representatives to be formulated into a constitutional amendment giving the Senate power to order the trial in cases of impeachment before twelve senators, the concurrence of eight of that number being necessary to secure a conviction. ${ }^{38}$

Whatever changes may be made should be with a view to the simplification of procedure and the economy of time, yet they should not destroy the independence of the judiciary so essential to the preservation of our government. The salutary effect of an impeachment such as that of Judge Archbald cannot be estimated. It will influence judicial behavior for many years to come. At the same time the judges will remain unawed and free to exercise those difficult functions which government in this country has laid upon them. 37 62d Cong., 3d Sess., S. J. Res. 152. 38 62d Cong., 3d Sess., H. J. Res. 384. 
- 


\section{INDEX}

Acts of Congress: Act of March 23, 1792, with respect to invalid pensions, 39 ; judiciary act of 1789 , 51 ; judiciary act of 1801 , 53 ; repeal of judiciary act of $1801,61.76$; attempt to repeal 25th section, judiciary act of 1789, 138; act of April 10 , 1869, granting pensions for disability, 190.

Adams, John: condemns subjection of judiciary to crown, 3 ; makes partisan appointments to judiciary in 1801, 55-57; demands power of impeachment in colonial legislatures, 101. Adams, John Quincy: describes trial of Pickering, 117 ; dissents from vote to remove Massachusetts judges, 127.

Addison, Alexander: makes partisan charges to juries, 46 ; impeached and removed, 111.

Age limits: in New York constitution, 4; unpopu- larity of, 186; proposed for federal judges, 192. Arizona legislature: petitions for abolition of commerce court, 86 .

Ashley, James M.: proposes age limits for federal judges, 188.

Archbald, Robert W.; appointed to commerce court, 145; c harges against, 145-147; articles of impeachment against, 149-152; conviction of, 152.

Bacon, Augustus O.: in debate on abolition of commerce court, 93.

Bassett, Richard: appointed to circuit court, 56 .

Bayard, James A.: denounces repeal of judiciary act of 1801,76 .

Bayard v. Singleton, case of, 19-20.

Blackstone, Sir William: tenth rule for construing statutes, 14; theory of Parliamentary supremacy, 195. 
Board of Trade: recommends change in tenure of colonial judges, 2.

Borah, William E.: in debate on abolition of commerce court, 91.

Bradbury, Theophilus: removed on address, 128.

Breckinridge, John: moves repeal of judiciary act of 1801, 66; denies doctrine of judicial review, 71 .

Buchanan, James: quoted, 142.

Butler, Pierce: opposes creation of inferior courts, 35; opposes judiciary act of 1789,51 .

Chase, Associate Justice: impeachment and acquittal of, 120-123.

Commerce court : established, 78 ; charges against judges of, 79 ; jurisdiction of, 82 83 ; attempts to enlarge its jurisdiction, 84.86 ; movement to abolish, 88 . 94.

Congress: empowered to establish inferior courts, 36 ; passes act to regulate claims to invalid pensions, 39 ; ereates circuit courts, 47-48, 53-55; es- tablishes inferior courts, 51-53; repeals judiciary act of 1801, 66-76; abolishes commerce court, 7994; power of, over inferior courts, 98-100; provides pensions for disabled judges, 190.

Contempt of court: defined in Pennsylvania, 113.

Council of Appointment: selects New York judges, 5 ; advised by the legislature, 15.

Council of Censors: adopted in Pennsylvania, 7 ; copied in Vermont, 7; recommendations of, in Pennsylvania, 9 .

Council of Revision: adopted in New York, 7; rejected by federal convention, 24.

Davis, Woodbury: removed from office, 133.

Declaration of Independence: quoted, 2.

Dickinson, John: proposes removal of judges on address in federal convention, 29.

Dodd, Walter F.: quoted, 199.

"Due process of law": meaning of, 200-201. 
Eastman, Nehemiah: proposes age limits for federal judges, 188.

Ellsworth, Oliver: succeeds John Jay as Chief Justice, 47; denounces Republicans, 47.

Employers' Liability Cases, 197.

Executive appointment: in early State constitutions, 5 ; advocated in federal convention, 31 ; denounced in Maryland constitutional convention, 176; supplanted by popular election, $181 \mathrm{ff}$; criticism of, $210 \mathrm{ff}$.

Federal convention: Randolph's plan of government, 22; the New Jersey plan, 23; rejects Council of Revision, 24; attitude of, towards judicial review, 25-27; gives federal judiciary power to negative State laws, 2729 ; grants federal judges tenure during good behavior, 29-30; debate in, on selection of judges, 31 33 ; debate in, on establishment of inferior courts, 34-36; adopts impeach. ment procedure, 103-107. Ford, Henry Jones: quoted, 46-47.

Fourteenth Amendment: influence of, on judicial review, 201.

Genêt, Edmund: in controversy with Washington, 43.

George III: alters tenure of colonial judges, 2 ; grants salaries to judges, 3 .

Gerry, Elbridge: defends judicial review, 25; denies power of Congress to construe laws, 38.

Giles, William B.: urges repeal of judiciary act of 1801, 58-59; theory of judicial tenure, 73 ; theory of impeachments, 120 122; in Virginia conven. tion of 1830,170 ; urges legislative control of courts, 170.

Goddard, Calvin: distinguishes between power to abolish an office and removal of the incumbent, 75.

Good behavior: established by Long Parliament, 2; granted colonial judges, 2 ; adopted in early State 
constitutions, 4; proposed by Randolph for federal judges, 23 ; proposals to abandon, in the United States, 167; abandoned in State constitutions, $171 \mathrm{ff}$.

Gorham, Nathaniel: proposes selection of judges by Executive and Senate, 32.

Greene, Ray: appointed to district court, 56 .

Greer, Associate Justice: forced to retire, 190 .

Haines, Charles G.: quoted, 201.

Hamilton, A lexander: praises the federal judicial system, 36; expounds doctrine of judicial review, 37-38; view of impeachments, 106, 119 ; condemns popular election of judges, 212.

Harrison, Nathaniel: removed on address, 131. 132.

Hayburn's Case, 40-41.

High crimes and misdemeanors: inserted in impeachment clause, 104; meaning of, 105-106; as construed in Chase im. peachment, 142; as construed in Archbald im. peachment, 153.

Hill, William H.: appointed to district court, 56.

Holmes v. Walton: case of, 11.

Hull, Cordell: offers substitute for impeachment, 140.

Humphreys, West H.: impeachment and removal of, 143.

Impeachment: denied colonial legislatures, 101 ; provided in Pennsylvania, 101; adopted by federal c onvention, 103-107; judges in Hayburn's case threatened with, 108; Jefferson's eriticism of, 109 110; of Judge Addison, 111; of Pennsylvania judges, 112; of $\mathrm{Oh}$ i o judges, 113; of Judge Pickering, 116-119; of Associate Justice Chase, 120-123; theory of, in Massachusetts, 126-127; substitutes for, 140-141; weaknesses of, 142-143; of Judge Humphreys, 143; of Judge Archbald, 144153 ; proposed modifica- 
tions in procedure of, 221 223.

Independence of the judiciary: meaning of, 1 ; extent of, in early State constitutions, $4 \mathrm{ff}$; theory of James M. Varnum, 18; attitude of federal convention towards, $123 \mathrm{ff}$.; attacked by partisans of Jefferson, 73; attitude of Jacksonian faction towards, $168 \mathrm{ff}$.; in England, 194; importance of, in the United States, $196 \mathrm{ff}$.

Inferior courts: debate in federal convention on, 3436 ; opposition to creation of, in first Congress, 5153; changes in, 1801, 54; affected by repeal of judiciary act of 1801, 75; affected by abolition of commerce court, 78-94; judicial decisions on power of Congress in relation to, 96-97.

Ingersoll, Jared: appointed to circuit court, 56 .

Interstate commerce commission: power of, under Hepburn Amendment, 80; "positive" and "negative"' orders of, 81-82.
Iredell, James: upholds doctrine of judicial review, 20.

Jay, John: resigns as Chief Justice, 44.

Jefferson, Thomas : criticism of legislative control of the courts, 8; criticises court in Matthew Lyon's case, 48; suggests repeal of judiciary act of 1801, 60 ; criticism of impeachment procedure, 109-110; directs impeachment of Judge Pickering, 110; denounces tenure during good behavior, 136-137; refuses to recognize doctrine of judicial review, 164; advocates term of years for judicial office, 165.

"Judge breaking"': in Pennsylvania, 112.

Judicial review: right of, denied in Vermont, 9; in New Jersey, 11-13; in New York, 13-16; in Rhode Island, 16-19; in North Carolina, 19-20; attitude of federal convention towards, 25-27; of State laws by federal courts, 27-29; defended in 
the "'Federalist,"' 37; upheld in first Congress, 3839 ; first exercise of, by federal courts, 39-43; in Ohio, 113; asserted by United States Supreme Court, 159; accepted by State courts, 159; opposition in Ohio, 160; upheld in Georgia, 161; in Connecticut, 162; denounced by Jefferson, 164; defended by Madison, 166 ; scope of, 195-198; recent growth of, 201.

Judicial tenure: in colonies, $2-3$; in early State constitutions, 4 ; theory of, in federal convention, 23-33; discussed in debate on creation of inferior courts, 52 ; theory of John Taylor, 61-66; discussed in debate on repeal of judiciary act of 1801, 66-76; discussed in debate on abolition of commerce court, 88-94; theory of John Marshall, 98; in State constitutions, $171 \mathrm{ff}$.; necessity for security of, $205 \mathrm{ff}$.

Kent, Chancellor: age limits force retirement of, 186.
Key, Philip Barton: appointed to circuit court, 56.

Kittera, John Wilkes: appointed United States district attorney, 57.

Lansing, John: opposes federal negative on State laws, 27.

Lecompte, Joseph: proposes term of years for federal judges, 167.

Lee, Charles: appointed to circuit court, 56 .

Lee, Henry: opposes creation of inferior courts, 51.

Legislative appointment: in early State constitutions, 5 ; discussed in federal convention, 31-33; evils of, 179-180.

Loring, Charles Greeley: removed on address, 133.

Lyon, Matthew: punished for sedition, 48 .

McIlwain, Charles H.: quoted, 217.

McKean, Thomas: rejoices over removal of Judge Ad. dison, 111.

McReynolds, James C.: proposes plan for retirement of federal judges, 191. 
Macon, Nathaniel: attacks tenure during good behavior, 165.

Madison, James: criticism of State constitutions, 6 ; proposes selection of judges by Senate, 32 ; in debate on President's power of removal, 38; d e f e $\mathrm{n} \mathrm{d} \mathrm{s}$ creation of inferior courts, 52 ; in debate on impeachment power, 104; defends course of federal judiciary, 166.

Marbury v. Madison : case of, 159.

Marey, William L.: criticises New York courts, 175.

Marshall, John: view of the repeal of the judiciary act of 1801, 98; defines doctrine of judicial review, 159; great constitutional decisions of, 137 ; in Virginia convention of 1830, 170; opposes legislative control of courts, 171.

Martin, Luther: defends judicial review, 26 ; drafts clause giving federal courts negative over State laws, 28.
Mason, George: in debate on impeachment power, 104. Mason, Jonathan: urges necessity for independent judiciary, 71 .

Mason, Stevens Thomson: condemns judiciary act of 1801,57 ; theory of judicial tenure, 67-68.

Mercer, John Francis: argues for independent judiciary, 24.

Merrill v. Sherburne: case of, 159.

"'Midnight judges"': petition Congress, 76.

Moody, Associate Justice: retired on account of disability, 190; defines judicial review, 197.

Morris, Gouverneur: opposes federal negative on State laws, 28; opposes selection of judges by Senate, 32 ; in debate on repeal of the judiciary act of 1801, 69-72.

Murray, William Vans : urges law to require courts to give notice when declaring acts void, 42 .

Nelson, Knute: opposes depriving judges of com- 
merce court of their commissions, 89-90.

Nevada Railroad Commission: petitions for abolition of commerce court, 86.

"Notes on Virginia"': quoted, 8.

O'Gorman, James A.: in debate on abolition of commerce court, 94.

Oliver, Chief Justice: attempt to impeach before colonial legislature, 3 .

Otis, James: argument of, in Writs of Assistance case, 10.

Otis, Harrison Gray: appointed United States district attorney, 57.

Owen, Robert S.: proposes "legislative recall" of judges, 141.

Paine, Elijah: appointed to district court, 56 .

Passmore, Thomas: petitions Pennsylvania legislature, 112.

Pease, Calvin: impeached and acquitted, 113; office declared vacant, 114; reelected, 161.
Phillips, Wendell: argues for removal of Judge Loring, 133.

Pickering, John : misconduct of, 115; impeachment and removal of, 116-119.

Pickering, Timothy: quoted, 122.

Pinckney, Charles: argues for separation of legislative and judicial departments, 24; advocates selection of judges by legislature, 32.

Popular election of judges: embodied in Georgia constitution 1776, 4; adopted in State constitutions, 179 ff.; proposed for inferior federal courts, 185 186 ; evils of, 209 ; condemned by Hamilton, 212. Procter and Gamble Company v. United States: case of, 84.

Public opinion: influence of, 214.

Randolph, Edmund: introduces plan of federal government, 22; l a m en ts weakness of federal judiciary, 44; seeks responsibility in selecting judges, 208. 
Randolph, John: theory of judicial tenure, 74 ; manager in trial of Justice Chase, 122; proposes removal of judges on address, 123; in Virginia convention of 1830,170 .

Read, Jacob: appointed to district court, 56 .

Reading, Lord: quoted, 204. Removal on address: rejected by federal convention, 30; proposed by John Randolph for federal judges, 123; adopted in England, 124; copied in early State constitutions, 125; purpose of, 126; in Massachusetts, 126-128; in Kentucky, 128-129; in New Hampshire, 130; in West Virginia, 131-132; in Maine, 132-133; decline in use of, 134; struggle to introduce, in federal government, 135-141; practice of, in England, 216-218; insufficiency of, 221.

Root, Elihu: statement upon conviction of Judge Archbald, 148; quoted, 206.

Rutledge, John : opposes creation of inferior courts, 34.
Rutgers $v$. Waddington : case of, 13-16.

Selection of judges: in early State constitutions, 156 157; in Ohio constitution of $1802,157-159$; reaction against legislative and executive methods in, 171-172; adoption of popular election for, 179-186; debates on, in federal convention, 207-208; criticism of, $210-215$.

Separation of powers: theory of Montesquieu, 5; as stated in Massachusetts constitution, 6 .

Sherman, Roger: advocates selection of judges by legislature, 32 ; opposes creation of inferior courts, 34 . Shields, John K.: in debate on abolition of commerce court, 91.

Smith, Hoke: in debate on abolition of commerce court, 90-91.

Spaight, Richard D.: denounces exercise of judicial review, 20.

Spencer, Ambrose: quoted, 143.

Stare decisis: weakness of, in constitutional law, 203204. 
Stone, David: contends for power of Congress to remove judges, 69 .

Story, Joseph : condemns repeal of judiciary act of 1801,78 ; view of removal on address, 127.

Taft, William Howard: opposes abolition of commerce court, 88 .

Taylor, John: theory of judicial tenure, 61-66.

Term of office: proposition to limit, 167; limited in State constitutions, 172 177 ; lengthened, 182-183.

Trevett $v$. Weeden: case of, 16-19.

Varnum, James M.: argues in defense of Rhode Island judges, 18.
Walsh, Thomas J.: in debate on abolition of commerce court, 92-93.

Washington, George: asks advice of judges, 43 ; farewell address quoted, 45 .

Williamson, Hugh: moves adoption of impeachment clause, 104.

Wilson, James: argues for Council of Revision, 26; opposes selection of judges by legislature, 31 .

Wilson, Woodrow: attitude of, on abolition of commerce court, 95.

Wiuslow, John B.: quoted, 213-214.

Wolcott, Oliver: appointed to circuit court, 56 .

Works, John D.: argues for broad view of impeachment power, 147-148.

Writs of Assistance: case of, 10. 

RETURN TO DESK FROM WHICH BORROWED

\section{LOAN DEPT.}

This book is due on the last date stamped below, or on the date to which renewed.

Renewed books are subject to immediate recall.

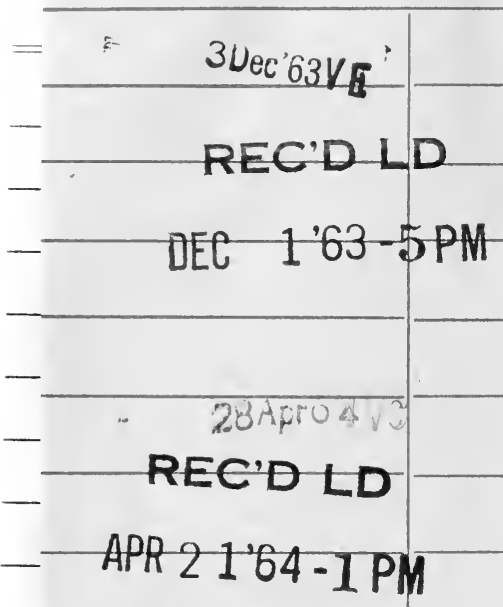

SEF \% 51910

PES SH: DEC $8 \cdot 76$ 


\section{YB 08418}

628842

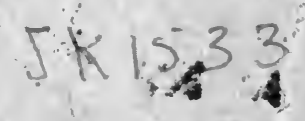

UNIVERSITY OF CALIFORNIA LI:RARY 
